$$
\text { DOE/YMSCO }-.98004267
$$

\title{
SITE ENVIRONMENTAL REPORT
}

\section{FOR}

\author{
CALENDAR YEAR 1996
}

NOVEMBER 1997

U.S. Department of Energy

Yucca Mountain Site Characterization Office

P.O. Box 30307

North Las Vegas, Nevada 89036-0307

DUSTFIBUTION OF THIS DOCUMENT IS UNLIMITED 


\section{DISCLAIMER}

Portions of this document may be illegible electronic image products. Images are produced from the best available original document. 


\section{SITE ENVIRONMENTAL REPORT}

\section{PREFACE}

The environmental program established by the Yucca Mountain Site Characterization Office (YMSCO) has been designed and implemented to protect, maintain, and restore environmental quality, minimize potential threats to the environment and the public, and comply with environmental policies and U.S. Department of Energy (DOE) Orders. In accordance with DOE Order 5400.1, General Environmental Protection Program (DOE, 1990a), to be superseded by DOE Order 231.1 (under review), the status of the Yucca Mountain Site Characterization Project (YMP) environmental program has been summarized in this annual Site Environmental Report (SER) to characterize performance, document compliance with environmental requirements, and highlight significant programs and efforts during calendar year 1996. 


\section{TABLE OF CONTENTS}

Page

1.0 EXECUTIVE SUMMARY $\ldots \ldots \ldots \ldots \ldots \ldots \ldots \ldots \ldots \ldots \ldots \ldots \ldots \ldots$

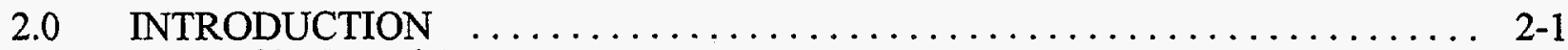

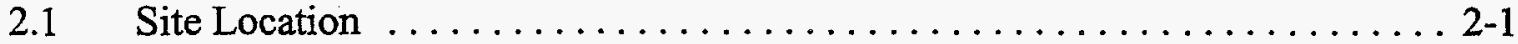

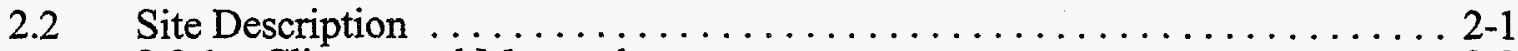

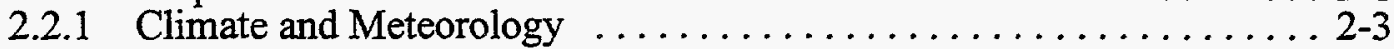

2.2 .2 Geology ............................... 2-4

2.2 .3 Water Resources ........................... 2-5

2.2 .4 Biological Resources . . . . . . . . . . . . . . . . . . . . 2-6

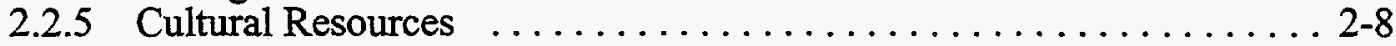

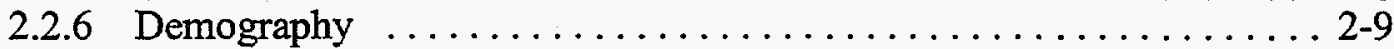

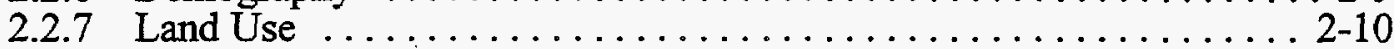

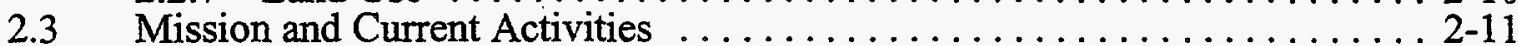

2.4 Environmental Reporting ........................ 2-12

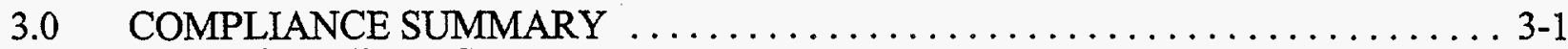

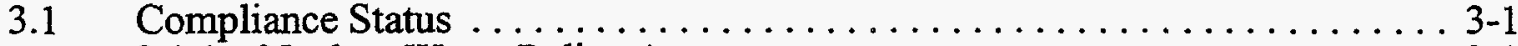

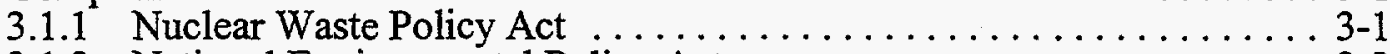

3.1.2 National Environmental Policy Act . . . . . . . . . . . . . 3-3

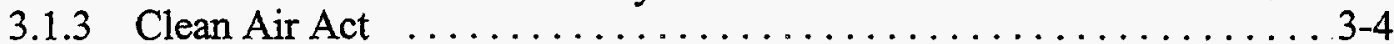

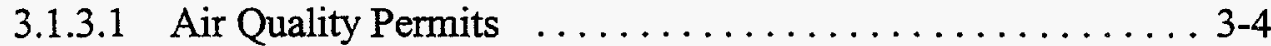

3.1.3.2 Ozone-depleting Substances . . . . . . . . . . . . 3-7

3.1.4 Clean Water Act . . . . . . . . . . . . . . . . . . . . 3-7

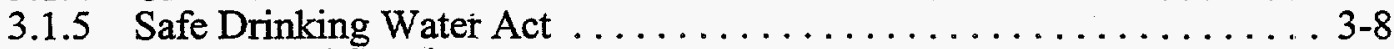

3.1 .6 Endangered Species Act . . . . . . . . . . . . . . . . . . . 3-9

3.1.7 National Historic Preservation Act and Associated

Cultural Resource Legislation Affecting

Archaeology and Native Americans ................. 3-10

3.1.7.1 Research and Data Recovery ................ 3-11

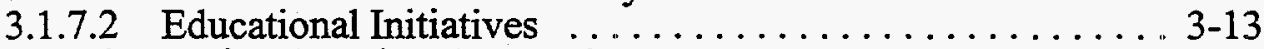

3.1.7.3 Native American Interactions $\ldots . . \ldots \ldots . . . . . . .3-14$

3.1.8 Comprehensive Environmental Response,

Compensation and Liability Act ................. 3-15

3.1.9 Resource Conservation and Recovery Act $\ldots \ldots \ldots \ldots \ldots \ldots \ldots$ 3-16

3.1.10 Federal Land Policy and Management Act . . . . . . . . . . . 3-17

3.1.11 Farmland Protection Policy Act . . . . . . . . . . . . . . . . 3-17

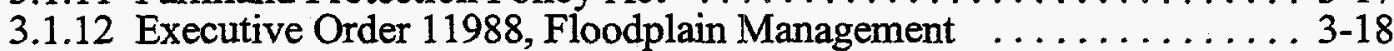

3.1.13 Executive Order 11990, Protection of Wetlands . . . . . . . . . . 3-18

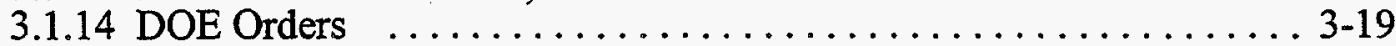

3.1 .15 Nevada Law . . . . . . . . . . . . . . . . . . 3-20

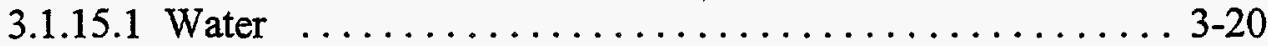

3.1.15.2 Hazardous Materials ................. 3-22

3.1.16 Environmental, Safety, and Health Assessments . . . . . . . . 3-23

3.1.17 Environmental Surveillance Program ................ 3-24

3.2 Summary of Permits and Compliance Actions $\ldots \ldots \ldots \ldots \ldots \ldots \ldots \ldots . \ldots \ldots$ 3-24

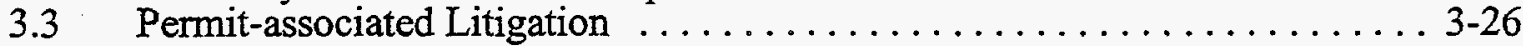


TABLE OF CONTENTS (Cont'd)

Page

4.0 ENVIRONMENTAL PROGRAM INFORMATION $\ldots \ldots \ldots \ldots \ldots \ldots \ldots .4$

$4.1 \quad$ Waste Minimization $\ldots \ldots \ldots \ldots \ldots \ldots \ldots \ldots \ldots \ldots \ldots \ldots \ldots \ldots \ldots \ldots, 4,1$

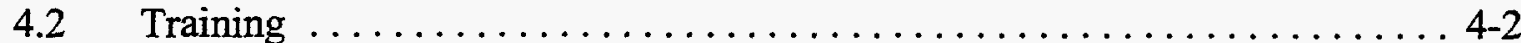

4.3 Environmental, Safety, and Health Assessment Program ............ 4-3

4.4 Environmental Surveillance Program $\ldots \ldots \ldots \ldots \ldots \ldots \ldots \ldots \ldots .4-6$

5.0 ENVIRONMENTAL RADIOLOGICAL PROGRAM $\ldots \ldots \ldots \ldots \ldots \ldots .5$ - 1

6.0 ENVIRONMENTAL NON-RADIOLOGICAL PROGRAM $\ldots \ldots \ldots \ldots \ldots \ldots, 6-1$

$6.1 \quad$ Monitoring Program Summary $\ldots \ldots \ldots \ldots \ldots \ldots \ldots \ldots \ldots \ldots, 6,1$

6.1.1 Terrestrial Ecosystem $\ldots \ldots \ldots \ldots \ldots \ldots \ldots \ldots \ldots \ldots \ldots \ldots, 6-1$

6.1.1.1 Site Characterization Effects $\ldots \ldots \ldots \ldots \ldots \ldots \ldots \ldots, 6-1$

6.1.1.2 Desert Tortoise Program $\ldots \ldots \ldots \ldots \ldots \ldots \ldots \ldots \ldots \ldots, 6,6$

6.1.1.3 Habitat Reclamation Program $\ldots \ldots \ldots \ldots \ldots \ldots \ldots .6 .6-10$

6.1.1.4 Monitoring and Mitigation Program $\ldots \ldots \ldots \ldots \ldots \ldots, 6-16$

6.1.1.5 Biological Sample Collection $\ldots \ldots \ldots \ldots \ldots \ldots \ldots \ldots, 6-18$

6.1 .2 Archaeological Resources $\ldots \ldots \ldots \ldots \ldots \ldots \ldots \ldots \ldots \ldots \ldots 6-18$

6.1 .3 Air Quality $\ldots \ldots \ldots \ldots \ldots \ldots \ldots \ldots \ldots \ldots \ldots \ldots \ldots, 6,19$

6.1 .4 Meteorology $\ldots \ldots \ldots \ldots \ldots \ldots \ldots \ldots \ldots \ldots \ldots \ldots, 6,19$

6.1.5 Water Resources .............................. 6-23

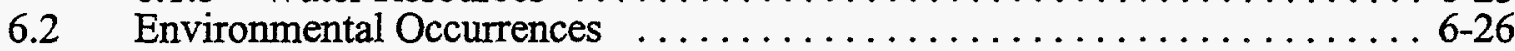

7.0 GROUNDWATER PROTECTION $\ldots \ldots \ldots \ldots \ldots \ldots \ldots \ldots \ldots \ldots \ldots \ldots \ldots \ldots \ldots \ldots$

8.0 QUALITY ASSURANCE $\ldots \ldots \ldots \ldots \ldots \ldots \ldots \ldots \ldots \ldots \ldots \ldots \ldots \ldots \ldots .1$

$8.1 \quad$ Overview $\ldots \ldots \ldots \ldots \ldots \ldots \ldots \ldots \ldots \ldots \ldots \ldots \ldots \ldots \ldots, \ldots, 1$

8.2 Sample Control $\ldots \ldots \ldots \ldots \ldots \ldots \ldots \ldots \ldots \ldots \ldots \ldots \ldots \ldots, 8,3$

$8.3 \quad$ Sample Analysis $\ldots \ldots \ldots \ldots \ldots \ldots \ldots \ldots \ldots \ldots \ldots \ldots \ldots, \ldots, 3$

8.4 Instrument Control $\ldots \ldots \ldots \ldots \ldots \ldots \ldots \ldots \ldots \ldots \ldots \ldots \ldots \ldots, \ldots, 4$

8.5 Data Management $\ldots \ldots \ldots \ldots \ldots \ldots \ldots \ldots \ldots \ldots \ldots \ldots \ldots .4$

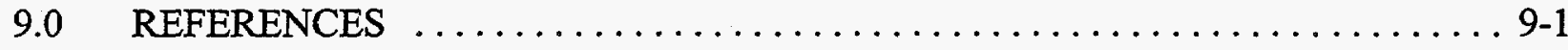

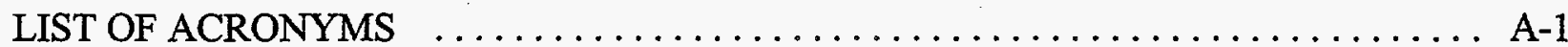




\section{LIST OF TABLES}

Table

3-1 Permitting Applicable to Site Characterization

Activities (Federal)

3-2 Permitting Applicable to Site Characterization

Activities (Federal Flowdown)

3-3 Permitting Applicable to Site Characterization

Activities (State)

4-1 Summary of 1996 Assessment Results $\ldots \ldots \ldots \ldots \ldots \ldots \ldots \ldots \ldots$

5-1 Synopsis of the Environmental Radiological Field

Monitoring Program in 1996

\section{LIST OF FIGURES}

Figure

Page

2-1 Location of the Yucca Mountain Site

2-2 Annual Total Precipitation at Site 1 (NTS-60) from 1986-1996

3-1 Near-field Radiological Monitoring Sites

5-1 Ambient Gamma Radiation Expressed as Average of Readings from

Near-field (NF) and Far-field (FF) TLD Stations per Calendar Quarter since 1991

5-2 Ambient Gamma Radiation Detected by PIC Units at the two Near-field

Sites, NF06 and NF87, since mid-1992

5-3 Monthly Average Radon Concentrations Measured by Continuous Radon

Monitors (Pylon) at the two Near-field (NF) Locations since 1995 . . . . . . . . . 5-4

5-4 Average Annual Gross Alpha Radioactivity at five Near-field (NF)

Locations as Detected by Continuous Air Samplers since 1993

5-5 Average Annual Gross Beta Radioactivity at five Near-field (NF)

Locations as Detected by Continuous Air Samplers since 1993

6-1 Air Quality and Meteorology Monitoring Sites

6-2 Inhalable Particulate Matter $\left(\mathrm{PM}_{10}\right)$ Measured in 1996 at the four Yucca Mountain Air Quality Monitoring Sites: 1 (NTS-60), 5 (Fortymile Wash), 6 (WT-6), and 9 (Gate 510) 


\section{LIST OF FIGURES (Cont'd)}

Figure

Page

6-3 Study Area for the Yucca Mountain Project Water Resources Program . . . . . . . 6-24

6-4 Groundwater Level and Discharge Monitoring Sites in the Yucca Mountain

Region, Southern Nevada and Eastern California $6-25$ 


\section{SITE ENVIRONMENTAL REPORT}

\subsection{EXECUTIVE SUMMARY}

Throughout most of 1996, reports emanating from the Exploratory Studies Facility (ESF) tunnel being excavated through Yucca Mountain were highly encouraging. The tunnel-boring machine (TBM) was progressing by as many as 58 meters (m) or 190 feet (ft) a day and, as late as July, was 150 days ahead of schedule. As the TBM neared a point approximately $760 \mathrm{~m}$ $(2,500 \mathrm{ft}$ ) from its projected exit point (and 7.1 kilometers [km] or 4.4 miles [mi] from its North Portal entry point), the rock type to be penetrated changed dramatically. Designated Category 4, the ground conditions encountered through most of December required the installation of ribs and steel lagging in the tunnel, significantly slowing progress. Nevertheless, as the year ended, the machine was less than $0.8 \mathrm{~km}(0.5 \mathrm{mi})$ from its anticipated "daylighting", an event expected to occur early in 1997 . By December 31 , the TBM had completed approximately $90 \%$ of its assigned 7.9-km (4.9-mi) loop through the mountain.

The shift of major site characterization activities to the ESF tunnel during calendar years (CY) 1995 and 1996, combined with the budgetary uncertainties of fiscal year (FY) 1995, caused some redirection of effort by the Yucca Mountain Site Characterization Project (YMP) environmental program in 1996 . Because many components of the program were essentially surface-based in nature and directly associated with land disturbance, the decline in development (drill pads, roads, boreholes, pits, trenches) above-ground had a noticeable effect. Less acreage disturbed for new activities equated to fewer of certain kinds of environmental matters to be considered. Several biological studies were scaled back or terminated, although in most instances, such measures were anticipated because adequate data (as much as seven years' worth) had been collected for analysis.

Most of the responsibilities of the YMP environmental program remained intact, however, throughout the year. It was still necessary to acquire or renew permits and to conduct 
frequent on-site surveillances of activities to ensure that conditions established by existing permits were being met. Whenever approval for a new activity was requested, a preactivity survey was still required, i.e., an inspection of the area of proposed activity for the presence of the officially threatened desert tortoise and its habitat, for objects of cultural interest or, in certain instances, for radionuclides in soil. Most of the original monitoring program, with its many technical disciplines, continued to generate new data to be used for future environmental analyses (e.g., the Yucca Mountain environmental impact statement [EIS]). Strong emphasis was once again placed on environmental training, waste minimization and, in particular, on recycling. Finally, as hazardous waste management issues became a greater concern everywhere, the YMP hazardous waste management program achieved new levels of efficiency in 1996. These, and other facets of the YMP environmental program, are summarized in the following paragraphs.

The permitting process, essential since the beginning of the Project to every activity undertaken, continued to provide the required State approvals for a variety of new and old tasks in 1996. The State of Nevada granted requests by the Yucca Mountain Site Characterization Office (YMSCO) to revise the Air Quality Operating Permit to include deletions of certain drill rigs no longer needed and to reduce the operating hours for a drill rig and two air compresscrs. Since revision of the permit in 1995, all known pollutant emissions have been sanctioned by the State under the conditions of this single air quality permit.

In January 1996, State actions to modify the Underground Injection Control (UTC) F'ermit were finalized. Changes included the addition of 50 boreholes for tracer injection experiments and the use of approximately a dozen chemical tracers. The modified permit also consolidated other existing individual Project permits to include surface discharges. Of major significance was approval by the State, in April 1996, to operate the newly constructed public drinking water system at Yucca Mountain. 
With most activities concentrated at the ESF North Portal and on operations underground, the number of requests for surveys in advance of proposed surface-disturbing activities declined in both 1995 and 1996. Nevertheless, these inventories, designed to protect ecological and cultural resources, are no less important now than in the past. With the expected emergence of the TBM in early 1997, preparation of an exit pad (the South Portal) was necessary, requiring preactivity surveys for a road and the pad before clearing operations could commence. During the year, 11 archaeological and two biological preactivity surveys were conducted. Also carried out were ten resurveys, necessary whenever a previously approved activity is unavoidably delayed; two postactivity surveys, conducted upon completion of an activity; and 27 other surveys, performed "on-the-spot" for activities that will not significantly disturb land surfaces (e.g., soil sample collections and installation of seismometers).

As in previous years, monitoring was a major component of the Yucca Mountain environmental program. The technical areas contributing monitoring data and information to this Site Environmental Report (SER) were radiological field studies, air quality, meteorology, cultural (archaeological and Native American) resources, water resources, and terrestrial ecosystems.

The radiological monitoring program for 1996 included the quantification of ambient gamma radiation, ambient radon, and radionuclides, both naturally occurring and man-made, in the Yucca Mountain environment. Ambient gamma radiation and radon concentrations were determined using two monitoring techniques each, while a single method was used to measure gross alpha and gross beta radioactivities. Environmental media sampled and monitored were air, vegetation, biota, water and soil. In 1996, the YMP operated only near-field stations, i.e., monitoring units located within $16 \mathrm{~km}(10 \mathrm{mi})$ of the center of the Yucca Mountain radiological study area. 
YMP activities generated no airborne radiological emissions in 1996. To date, concentrations of radon and other monitored radionuclides have not exceeded ambient levels measured at other locations outside the boundaries of the NTS.

As last year, the air quality program monitored particulate matter 10 micrometers or less in diameter $\left(\mathrm{PM}_{10}\right)$ at four locations. The data indicate an annual trend of higher concentrations of these particulates during the summer months, although individual, somewhat elevated concentrations were recorded periodically throughout the year. The highest concentration of $\mathrm{PM}_{10}$ in a 24-hour period was less than half the 24-hour ambient air quality standard of 150 micrograms per cubic meter $\left(\mu \mathrm{g} / \mathrm{m}^{3}\right)$. Most values, in fact, were well below $20 \mu \mathrm{g} / \mathrm{m}^{3}$. The highest average of all 24-hour periods for any monitoring site was one-fifth the annual ambient air quality standard of $50 \mu \mathrm{g} / \mathrm{m}^{3}$.

The meteorology program continued to operate nine monitoring stations in the Yucca Mountain vicinity. The primary function of this program is to characterize local meteorological conditions and support future radiological transport calculations. The main station, Site 1 , recorded meteorological data at the surface and at three levels on its 60-m tower. Many of the same parameters (e.g., wind speed and direction, temperature, solar radiation, barometric pressure, and precipitation) were also measured at the other eight sites, each equipped with a 10-m tower. Precipitation totals at the various stations for 1996 were nearly identical to the long-term averages for those locations. For example, the total at Site 1 was 12.88 centimeters (cm) or 5.07 inches (in) versus the 11-year average at that site of $12.90 \mathrm{~cm}$ (5.08 in). Typical differences were observed between sites, however, ranging from a total of $7.06 \mathrm{~cm}(2.78 \mathrm{in})$ at Site 9 to $14.58 \mathrm{~cm}(5.74 \mathrm{in})$ at Site 6.

As a result of the 11 archaeological preactivity surveys mentioned previously, three new artifacts or historical sites were identified. Monitoring of 45 previously known historical properties indicated that all were in essentially the same condition as when discovered or last examined. In compliance with certain stipulations of the Programmatic Agreement between the 
U.S. Department of Energy (DOE) and the Advisory Council on Historic Preservation (ACHP), consultation and interactions with 17 Native American tribes and organizations continued in 1996. Two tribal update meetings were held, a variety of national meetings were attended by DOE personnel, and the DOE sponsored 47 speaking engagements and 42 educational forums during the year at which the YMP Native American program was explained to the public.

Measurements of groundwater levels in 35 wells, and of groundwater discharge (in-flow) into five springs and one flowing well, in the Yucca Mountain region continued throughout 1996. Comparisons of provisional data from monitoring well $\mathrm{JF}-3$ and two nearby production wells, $\mathrm{J}-12$ and $\mathrm{J}-13$, indicated that fluctuations in water levels during the year were $0.33 \mathrm{~m}(1.07 \mathrm{ft})$, $0.31 \mathrm{~m}(1.02 \mathrm{ft})$, and $0.22 \mathrm{~m}(0.72 \mathrm{ft})$, respectively.

The terrestrial ecosystem program, altered significantly in 1995, extended certain ongoing studies, initiated another, and issued or drafted (for release in 1997) several topical reports describing work completed in FY 95. One of the major components of the program in the past, a series of desert tortoise studies, generated a significant body of data now compiled and reported in four documents, one of which has been issued while three are presently under review. (These latter three reports were issued in early 1997.) Between 1989 and September 1995, 308 tortoises were radiomarked and monitored, and many others were marked (but with no transmitters attached) and observed, yielding the information presented in these reports. (Though these studies have concluded, the presence of tortoises at Yucca Mountain will still be noted during preactivity surveys, and the animals will be removed from harm's way whenever necessary.)

Two other major components of the terrestrial ecosystem program consist of (1) studies of biotic and abiotic factors at Yucca Mountain as a means of monitoring and mitigating the effects of site characterization on local flora and fauna, and (2) experiments to develop and test strategies and techniques for reclaiming disturbed areas. As with the desert tortoise program, many of these studies were scaled back or completed in 1995, with data being compiled and 
analyzed in 1996. A topical report for each of the following subject areas was issued during the year or prepared for release in 1977: vegetation, small mammals, and ravens (because of their potential as predators of the desert tortoise).

The habitat reclamation program continued several long-term studies throughout the year, and implemented seeding, mulching, and soil stabilization techniques at 20 sites released for final reclamation. Monitoring to detect and prevent soil erosion was conducted at numerous topsoil stockpiles and at 54 other sites, including trenches, pits, and drill pads. Data from 1991 to 1995 , analyzed in 1996 , revealed that direct seeding of native, adapted species resulted in successful revegetation during years of above-average precipitation. New studies initiated during late fall and winter 1996 were designed to test various irrigation regimens and the effects of dormancy-breaking treatments of seeds on the timing of germination. The objective of these studies is to enhance seedling emergence, plant establishment, and plant survival.

The YMP environmental program also includes an environmental assessment program and a field surveillance program. The assessment program functions to verify that YMP activities are performed in full compliance with all environmental requirements. In this role, assessment teams conducted five comprehensive assessments and eight focused, special-issue assessments in 1996. Surveillance program personnel routinely conduct unannounced "spot: checks" of YMP activities in the field to verify that all environmental requirements and regulations are complied with on site and that permit and right-of-way reservation (ROWR) conditions are met. In 1996, a total of 282 field surveillances were conducted.

Continued emphasis was placed on waste minimization and adherence to hazardous waste regulations in 1996. Recycling efforts were particularly successful, yielding, among other items, 302 tons of paper and approximately 35 tons of recyclable scrap metal. Also collected and transported to a recycling facility were tires, lead-acid batteries, used oil, antifreeze coolants, and used cleaning solvents. 
Six shipments of hazardous waste were transported to U.S. Environmental Protection Agency (EPA)-permitted disposal facilities, in accordance with Resource Conservation and Recovery Act (RCRA) requirements. To document that quantities of listed toxic chemicals used by the YMP during the course of the year were insufficient to activate the Emergency Planning and Community Right-to-Know Act (EPCRA) Section 313 reporting process, the YMSCO filed a negative report with the EPA. Further, none of these chemicals were released during the year. In compliance with Sections 302, 311, and 312 of EPCRA, reports will be filed with the appropriate State and/or county agencies to document the storage by the YMP in 1996 of seven substances in excess of their reporting thresholds: sulfuric acid, propane, diesel fuel, cement, kerosene, and lubricating and waste oils. During the year, no chemicals classified by the State of Nevada as highly hazardous were stored in quantities that exceeded their reporting thresholds.

Three State-reportable petroleum releases occurred in 1996 as a result of YMP activities. All were promptly reported, as required by law, and remedial action was performed at each release location. Approximately 65 tons of excavated, hydrocarbon-contaminated soil were sent during the year to an off-site, State-permitted treatment and recycling facility for bioremediation and ultimate use as landfill cover. In addition, 13,249 liters (3,500 gallons) of waste oil were transported to a permitted, off-site oil recycler. 


\subsection{INTRODUCTION}

\subsection{SITE LOCATION}

The area known as the "Yucca Mountain site" (or "the site" or "Project site") is situated on the southwestern boundary of the NTS and includes adjoining lands administered by the U.S. Air Force (USAF) and the Bureau of Land Management (BLM) (Figure 2-1). The USAF land comprises a small part of the Nellis Air Force Base Bombing and Gunnery Range (NAFR), and is used by the USAF for overflight purposes only. Access to both USAF and BLM land has been obtained by means of right-of-way reservations (ROWR) granted the DOE by each agency. The site is located in Nye County, Nevada, approximately 160 kilometers (km) or 100 miles (mi) northwest of the city of Las Vegas, Nevada (Figure 2-1).

\subsection{SITE DESCRIPTION}

Located in the southern Great Basin of the Basin and Range Province, the regional setting of the Yucca Mountain site may be generally characterized as consisting of linear mountain ranges separated by intervening valleys with ephemeral streams or rivers. Because little water is easily accessible, the region has been only sparsely settled. Historically, a few small communities have sprung up near mining operations but most are now abandoned or inhabited by relatively few permanent residents. The rocky desert soil, low in moisture and nutrient value, provides little opportunity for productive agriculture. In a few areas, however, groundwater is sufficiently shallow that irrigation of some crops has been possible.

Within this regional setting, the Project site encompasses ecological zones ranging from the Mojave Desert to the south (below 1,220 meters [m]; 4,000 feet [ft] elevation) through a transition zone (sometimes called the Transition Desert) which extends beyond the northern boundary of the site to the cooler and wetter Great Basin Desert (above 1,525 $\mathrm{m}[5,000 \mathrm{ft}]$ ). The 


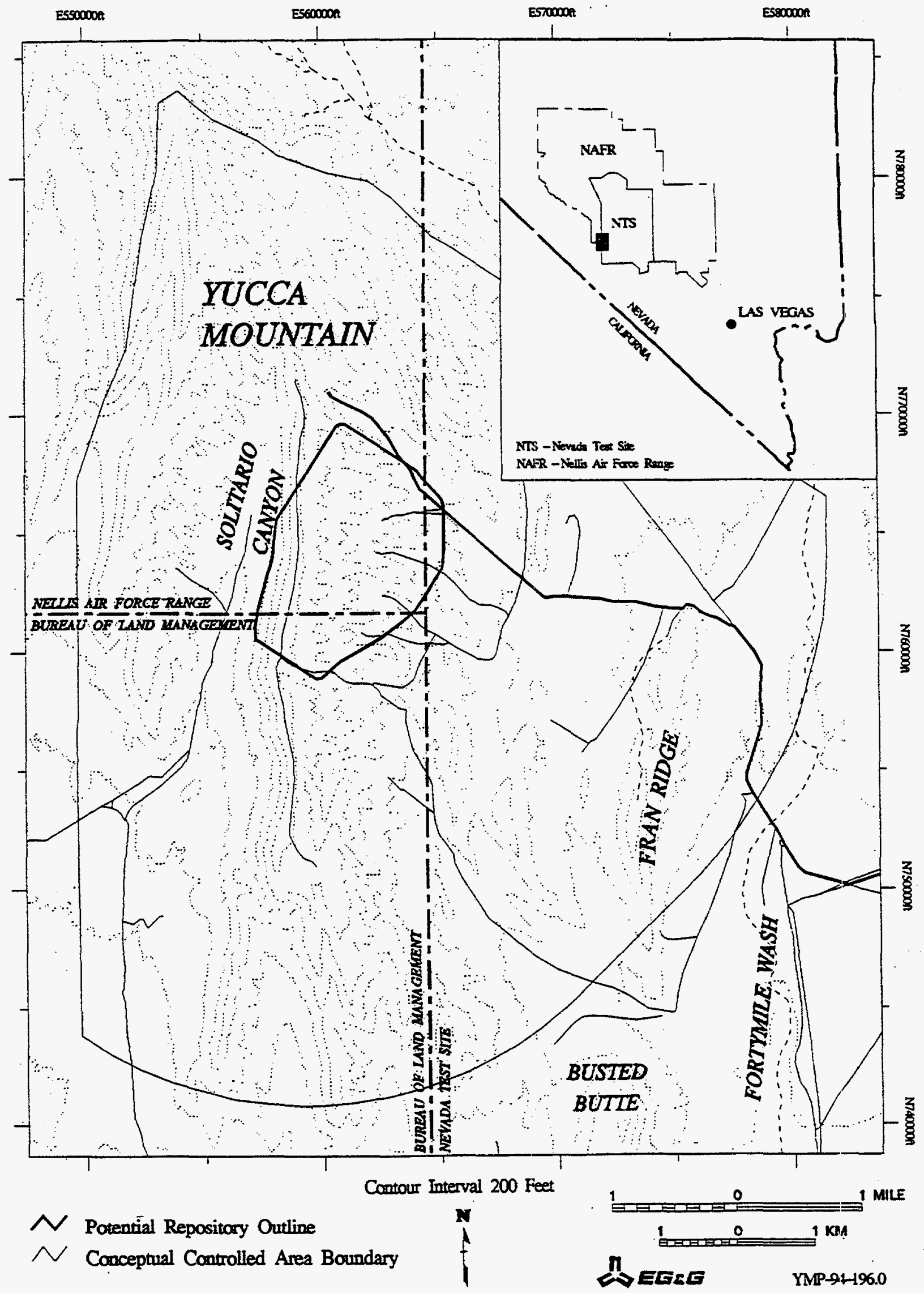

Figure 2-1. Location of the Yucca Mountain Site 
soils are generally rocky or sandy and dry, primarily supporting low bushes and shrubs. The major topographical feature of the site is Yucca Mountain itself, a long north to south-aligned volcanic ridge with an elevation of $1,494 \mathrm{~m}(4,900 \mathrm{ft})$. The mountain slopes steeply west to Crater Flat (elevation 1,189 $\mathrm{m}[3,900 \mathrm{ft}]$ ) and gradually eastward to Jackass Flats (elevation $1,097 \mathrm{~m}[3,600 \mathrm{ft}]$ ). Five sizable washes cross the site east of Yucca Mountain, the largest being Fortymile Canyon which drains to the Amargosa Valley.

The regional setting and natural features of the Yucca Mountain site are described in more detail in the Environmental Assessment (EA) prepared for the site (DOE, 1986).

\subsubsection{Climate and Meteorology}

Typical of southwestern deserts, the climate of the Yucca Mountain region is characterized by intense solar radiation, limited amounts and infrequent occurrences of precipitation, low relative humidity, and large diurnal temperature ranges. Local topography influences precipitation, temperature patterns, and wind direction and speed, as manifested by the diurnal mountain-valley, air-flow cycle. This cycle, which occurs in all seasons, produces predominant northerly to northwesterly winds at night and southerly to southeasterly winds during the day. Synoptic-scale winds, produced by frontal storm passages in winter, spring, and fall, and the southerly monsoon of summer, can enhance, neutralize, or reverse the predominant diurnal cycle.

Since late December 1985, meteorological data have been continually recorded at five sites on and around Yucca Mountain. Four additional stations were in operation by January 1993 (see Section 6.1.4). Typically, most of the total annual precipitation falls in winter with occasional snowfall at higher elevations. Summer thunderstorms can also produce significant rainfall over a relatively short period of time. For the period December 1985 through December 1996, annual precipitation at the Site 1 (NTS-60) meteorological tower averaged 12.90 
centimeters $(\mathrm{cm})$ or 5.08 inches (in). Annual precipitation totals at this site for the same period ranged from $3.66 \mathrm{~cm}$ (1.44 in) in 1989 to $23.57 \mathrm{~cm}$ (9.28 in) in 1995 (Figure 2-2). The greatest daily amount of precipitation recorded at Yucca Mountain during this period was $6.17 \mathrm{~cm}$ (2.43 in) occurring at the Site 7 (Sever Wash) meteorological station in December 1993.

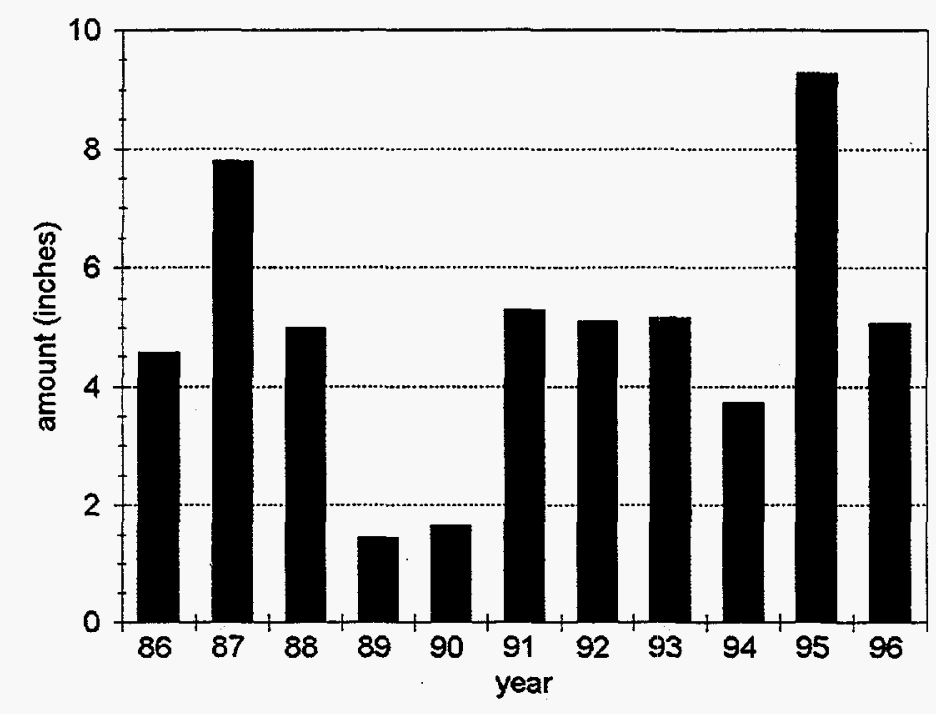

Figure 2-2. Annual Total Precipitation at Site 1 (NTS-60) from 1986-1996

\subsubsection{Geology}

Four major groups of rocks comprise the mountain ranges and basins in the region of the site (DOE, 1986). The first and oldest, Precambrian crystalline rock, is not exposed at Yucca Mountain but may occur beneath the site at great depths. The second, sedimentary rock including carbonates, is many thousands of feet thick and is overlaid in many places by the third group, volcanic tuffs and lava of Tertiary age. This third group, the result of eruptions preceding the collapse of large volcanic centers known as calderas, comprise at least the upper 2,000 m $(6,500 \mathrm{ft})$ of the total stratigraphic section at the site. The fourth group, Quaternary deposits, is represented at Yucca Mountain by alluvium derived from erosion of the nearby hills of sandstone 
and volcanic rock. Alluvial-fan deposits form aprons along the east and west flanks of the mountains.

In Crater Flat, west and southwest of Yucca Mountain, cinder cones of Quaternary age are conspicuous at the surface. It is estimated that the most recent major volcanic activity in the vicinity of the site occurred some 11 million years ago, forming the Timber Mountain caldera (between 16 and $24 \mathrm{~km}$ [10 and $15 \mathrm{mi}]$ north) (DOE, 1986). On June 29, 1992, an earthquake of 5.6 Richter magnitude occurred $21 \mathrm{~km}(12.5 \mathrm{mi})$ south of Yucca Mountain beneath Little Skull Mountain at a depth of approximately $5 \mathrm{~km}(3 \mathrm{mi})$. More than 1,000 aftershocks were recorded immediately thereafter, the largest of which was magnitude 4.0. In August 1994, an aftershock of magnitude 3.0, too small to be felt at Yucca Mountain, was detected at Little Skull Mountain. An even smaller event (magnitude 2.1) occurred the same month in Crater Flat, $10 \mathrm{~km}$ (6.2 mi) from the ESF. Since 1994, seismic activity in the region has been restricted to weak aftershocks and low-magnitude background events.

Seismic activity in the vicinity of Yucca Mountain is monitored continuously by a network of 22 seismic stations funded by the YMSCO. Also a part of the system are three microwave relay stations to assist in the transmission of data.

\subsubsection{Water Resources}

Free-flowing surface water does not exist at or near the Project site. All drinking water is pumped from groundwater sources. Water tables are generally deep beneath the surface of the ranges and most valleys. Recharge results from precipitation falling at higher elevations to the north. After percolating from the surface through the unsaturated zone that overlies the water table, water flows generally south and southwest. 
Beneath the Project site, water traverses two separate aquifers, one local and relatively shallow (at a depth of approximately $490 \mathrm{~m}[1,600 \mathrm{ft}]$ ), the other regional and very deep in the lower carbonate layer (probably in excess of 1,250 m [4,100 ft]) (DOE, 1986). The majority of the groundwater eventually discharges south and southwest of the site in Amargosa Valley and Death Valley.

\subsubsection{Biological Resources}

The major vegetation associations of the NTS and the surrounding region were described by Beatley (1976), whose classification was used to differentiate the four major vegetation associations in the immediate Yucca Mountain area. Plant species names follow the convertion of Kartesz and Pankhurst (1994), and the common names of plants follow Kartesz (1988).

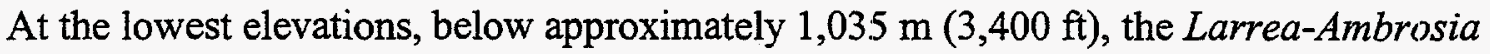
(creosote bush, white bursage) vegetation association occurs on generally flat (slope $=0$ to $2 \%$ ), sandy, alluvial soils. Larrea tridentata and Ambrosia dumosa are the dominant perennial shrubs.

At middle elevations, between approximately 1,035 and $1,310 \mathrm{~m}$ (3,400 and 4,300 fi:), the Larrea-Lycium-Grayia (creosote bush, desert thorn, hopsage) association occurs on the upper portions of bajadas (slope $=4$ to $6 \%$ ) and on rocky slopes. This association is typified by widely spaced creosote bush that forms a diffuse canopy, with Ephedra nevadensis (Nevada ephedra), $A$. dumosa, and Krameria erecta (littleleaf ratany) being subdominants in this association. Lycium andersonii (Anderson desert thorn) and Grayia spinosa (hopsage) are less common. This vegetation association is also characterized by an abundance of winter annuals such as Bromus rubens (red brome) and Amsinckia tessellata (common fiddleneck).

At middle elevations above approximately $1,100 \mathrm{~m}(3,600 \mathrm{ft})$, the Coleogyne (blackbrush) association occurs on the upper portions of bajadas with moderate slopes and few rocks (slope $=3$ to $5 \%$ ) and on flat ridge tops. This association is typically composed of nearly 
monospecific stands of Coleogyne ramosissima interspersed with several species of Chrysothamnus (rabbitbrush) and Ephedra. At Yucca Mountain, this association often intergrades over long distances with the Larrea-Ambrosia and Larrea-Lycium-Grayia associations.

At higher elevations, above approximately $1,310 \mathrm{~m}$ (4,300 ft), the Lycium-Grayia (desert thorn, hopsage) association occurs on ridge tops (slope $=6$ to $10 \%$ ) and on the higher, steeper, and rockier slopes. L. andersonii, G. spinosa, E. nevadensis, Eriogonum fasciculatum (California buckwheat), and a variety of shrubs from higher and lower elevations share dominance in this association.

At still higher elevations or on some cooler, north-facing slopes and ridges, species of Artemesia (sagebrush) become dominant in small areas within the Lycium-Grayia association. On adjacent areas of the NTS, at elevations above 1,524 $\mathrm{m}$ (5,000 ft), a pinyon-juniper association is found which is dominated by one or both of two dwarf conifers, Pinus monophylla (pinyon pine) and Juniperus osteosperma (Utah juniper).

Based on NTS records, as many as 46 species of mammals may occur in the vicinity of Yucca Mountain (Collins et al., 1982); however, only 36 species have been recorded at the Yucca Mountain site. At middle and higher elevations, the most common rodents were Merriam's kangaroo rats (Dipodomys merriami) and long-tailed pocket mice (Chaetodipus formosus), while at lower elevations, Merriam's kangaroo rats and little pocket mice (Perognathus longimembris) were most common. The remaining species were recorded from scent-station surveys, bat surveys, spotlight surveys, roadkills, and anecdotal observations. None of the mammals observed are considered threatened or endangered, although all are protected by the State of Nevada. Two species of bats captured at Yucca Mountain, Myotis volans (long-legged myotis) and Myotis thysanodes (fringed myotis), were candidates for listing under the Endangered Species Act (ESA) until 1996. A third bat species (Myotis ciliolabrum, the small-footed myotis), also a former ESA candidate, may have been captured but is difficult to differentiate from Myotis 
californicus (California myotis). Euderma maculatum (spotted bat), considered threatened by the State of Nevada and an ESA candidate until 1996, was neither seen nor detected at Yucca Mountain. The species was detected, however, about $30 \mathrm{mi}(50 \mathrm{~km})$ north of Yucca Mountain in higher-elevation regions of the NTS.

Site-specific surveys in 1982 recorded 35 species of birds (O'Farrell and Collins, 1983), and a database of bird observations made by YMP biologists has been maintained since January 1993. Although observations were not systematically recorded, 98 avian species have been observed at Yucca Mountain as of December 1996.

Twenty-seven (possibly 28) species of reptiles were observed during sampling operations conducted between 1991 and 1995 using a variety of techniques. Sampling was conducted throughout the Yucca Mountain site area, but most occurred within the three major low-elevation habitat types in and around Midway Valley. The most common lizards were the side-blotched lizard (Uta stansburiana) and western whiptail (Cnemidophorus tigris), while the most common snakes were the coachwhip (Masticophis flagellum) and longnose snake (Rhinocheilus lecontei). The threatened desert tortoise (Gopherus agassizii) and the former ESA candidate, western chuckwalla (Sauromalus obesus), were found in some areas.

\subsubsection{Cultural Resources}

Archaeological resources found at the Yucca Mountain site indicate significant past use by small and highly mobile groups of aboriginal hunter-gatherers, followed by limited use by Euroamericans for purposes of travel and transportation, prospecting, surveying and, possibly, ranching. The region may have been inhabited by humans as long ago as 12,000 years. At that time, most activity appears to have centered on a pattern of sites along major ephemeral drainages. By 7000 years Before Present (BP), a second settlement pattern was discernible, with the establishment of temporary camps in the uplands of Yucca Mountain, some distance from 
linear water sources. A third shift in the pattern of aboriginal settlement occurred approximately 1,500 years ago, indicated by the presence of sites, often with grinding stones, on alluvial fans or in small rockshelters in the Yucca Mountain uplands. At that time, sites were no longer being established along major drainages, perhaps indicating that such waterways were by then lacking significant water. Sites were usually located, instead, near small seasonal water sources such as tinajas.

A fourth and most recent period of settlement adaptation, a Euroamerican presence, is indicated by the discovery of rock cairns, tin cans, and temporary historic camps (DOE, 1990b). At the time of the first recorded arrival of Euroamericans in 1849, the area was inhabited by the Paiute and Shoshone Indians.

Numerous archaeological surveys have been conducted in the Project area. As a result, over 900 historical properties, ranging from single pottery shards to campsites, milling stations, and quarries, have been identified.

\subsubsection{Demography}

With the exclusion of Clark County to the southeast, the counties immediately surrounding the Yucca Mountain site are essentially rural and sparsely populated. Most residents are concentrated in a few small communities. County populations as of July 1, 1996, are as follows: Lincoln, 3,903 residents; Esmeralda, 1,180; Nye, 26,062; and Inyo (California) with 18,433 (U.S. Bureau of the Census, 1997). The exception is Clark County (1,048,717 residents), which includes the cities of Las Vegas, North Las Vegas, Henderson, Boulder City, and Mesquite (U.S. Bureau of the Census, 1997). Population density is extremely low (approximately 0.5 person per square kilometer $\left[\mathrm{km}^{2}\right]$ ) in these bordering counties (excluding Clark), relative to a 1992 estimate for the 48 contiguous states ( 33 persons per $\mathrm{km}^{2}$ ). 
A circular study area, $84 \mathrm{~km}(52 \mathrm{mi})$ in radius, is considered to be "the site" for radiological monitoring purposes. One community, Pahrump, is split by the southeast perimeter of the study circle. The estimated population, for the second quarter of 1996, of that portion of the town that lies within the study circle is 10,378 , while the total population within the town boundary is 16,038 (DOE, 1996a). The community of Amargosa Valley, 24 to $32 \mathrm{~km}$ (15 to 20 $\mathrm{mi}$ ) south and primarily agricultural, has a population of 1,136 . Beatty, approximately $32 \mathrm{~km}$ (20 mi) west, has 1,435 residents. Las Vegas, already large and growing rapidly, lies $160 \mathrm{~km}$ $(100 \mathrm{mi})$ to the southeast, well outside the study area boundary.

The only other concentration of population near the site occurs at Death Valley National Park, with an estimated population of 452 residents. The average number of visitors per day in 1994 was 2,760 (DOE, 1995a). As many as 30,000 may be present, however, for a brief period in November to celebrate "Death Valley Days."

\subsubsection{Land Use}

The area within which the Project site is located is controlled by three Federal agencies: the DOE, the USAF, and the BLM. Consequently, access to much of the land is restricted. In addition, because of the lack of surface water and the generally harsh desert conditions that prevail in the area, few opportunities exist for agriculture or recreation on lands immediately adjacent to the site. An exception is a limited amount of off-road driving that occurs in the surrounding area. The nearest agriculture of note occurs in the Amargosa Valley, approximately $24 \mathrm{~km}(15 \mathrm{mi})$ south. The Pahrump Valley, $97 \mathrm{~km}(60 \mathrm{mi})$ south and east, also contains significant farming operations. The BLM issues a limited number of grazing leases for southern Nye County, though none have been issued for lands surrounding the site.

Several small mines exist in southern Nevada, most of them to the southwest near the Nevada-California border. Two major active mining operations near the site are the 
Stirling-Panama Mine at Bare Mountain, approximately $19 \mathrm{~km}(12 \mathrm{mi})$ to the west, and the Bullfrog Mine operated by Barrick, Incorporated, near the town of Beatty.

Areas south and southwest of the site are popular throughout the year for camping, boating, hiking, hunting, fishing, and nature study. Two that are particularly well-known are the Ash Meadows National Wildlife Refuge (32 km [20 mi] away) and Death Valley National Park ( 32 to $40 \mathrm{~km}$ [20 to $25 \mathrm{mi}$ ] to its northeastern boundary). The former is especially unique because of its seeps and springs (in excess of 30), providing habitat for four endemic, endangered fish species.

\subsection{MISSION AND CURRENT ACTIVITIES}

The Nuclear Waste Policy Act (NWPA) of 1982, as amended in 1987, directs the DOE to conduct site characterization studies at Yucca Mountain to determine whether the site is suitable for the storage and isolation of high-level radioactive waste and spent nuclear fuel. Early studies undertaken in response to this mandate were surface-based only, as in conducting ecological investigations and digging trenches and shallow boreholes. In 1993, the emphasis began to shift underground as preparations proceeded for studies that would characterize the site geologically and hydrologically. Since mid-1994, the primary focus has been on the TBM, as it excavated a tunnel $7.6 \mathrm{~m}(25 \mathrm{ft})$ in diameter along a U-shaped path within Yucca Mountain. By December 31,1996 , the TBM had completed $7.1 \mathrm{~km}(23,400 \mathrm{ft} ; 4.4 \mathrm{mi})$ of the $7.9 \mathrm{~km}(4.9-\mathrm{mi})$ route extending from the North Portal tunnel entrance to the South Portal exit point. Along the way, six test alcoves were completed off the main tunnel. With construction of the seventh, and last, alcove underway as the year ended, some of the earliest experiments to be conducted in the first alcoves had been concluded. 
A number of exercises, initiated in previous years to characterize the site, were continued in 1996, e.g., infiltration studies, geologic mapping, assessments of volcanic and seismic hazards, and refinement of mathematical models predicting groundwater flow, radionuclide movement, and future climatic conditions. Among the investigations begun in 1996 were ESF thermal studies, the first of which commenced on August 26. Electrically generated heat, simulating heat released by stored nuclear waste, is being applied to the rock in alcove 5 (Thermal Test Facility) to determine the effects of elevated temperatures on hydrological, mechanical, and geochemical properties and processes. These tests, conducted to characterize the ability of the rock to safely contain waste, will continue for several years to come.

\subsection{ENVIRONMENTAL REPORTING}

This document is the sixth annual Site Environmental Report (SER) submitted by the Yucca Mountain Site Characterization Office (YMSCO) to describe the environmental program implemented by the DOE at Yucca Mountain. As prescribed by the NWPA, this program ensures that site characterization activities are conducted in a manner that minimizes any significant adverse impacts to the environment and complies with all applicable laws and regulations. The guidelines for the preparation of the SER (Memorandum from DOE, Office of Environmental Policy and Assistance, dated April 24, 1997) place major emphasis on liquid and gaseous emissions of radionuclides, pollutants or hazardous substances; human exposure to radionuclides; and trends observed by comparing data collected over a period of years. To date, the YMP has not been the source of any radioactive emissions or been responsible for any human exposure to radionuclides. Minuscule amounts of radioactivity detected at the site are derived from natural sources or from dust previously contaminated by old NTS tests. Because data for only a few years exist for the site, identification of long-term trends is not yet possible. 
Despite the lack of the aforementioned categories of information requested for the SER, the YMP has collected considerable material relevant to this report. An extensive environmental monitoring and mitigation program is currently in place and is described herein. Also, as requested by the SER guidelines, an account of YMP compliance with appropriate environmental legislation is provided. 


\subsection{COMPLIANCE SUMMARY}

This chapter briefly discusses environmental legislation that is applicable to DOE activities at Yucca Mountain, and summarizes YMP compliance actions and the results of those actions during 1996. A summary of permits and the status of each is presented at the end of the chapter in Tables 3-1, 3-2, and 3-3.

\subsection{COMPLIANCE STATUS}

\subsubsection{Nuclear Waste Policy Act (NWPA)}

Section 113(a) of the NWPA, as amended, stipulates that the Secretary of Energy shall carry out appropriate site characterization activities at the Yucca Mountain site. It further states that such activities shall be conducted in a manner that minimizes, to the maximum extent practicable, any significant adverse environmental impacts. For the second year in a row, the primary effort to characterize the site took place underground, as the TBM traversed the longest leg of the ESF tunnel (i.e., the north-south main drift) and began its gradual ascent to its planned exit, anticipated in early 1997.

As the TBM progressed, experiments were already underway in the first five of six alcoves, or underground laboratories, excavated off the main drift; a seventh alcove is not yet complete. Most of these research efforts are designed to reveal the ways in which fluids and gases (including water and water vapor) move within and between the rock types that comprise the mountain. Another series of tests, initiated in August and scheduled to extend over several years, will investigate the effects of long-term heat on the rock and on the movement of water through the rock. 
As required by the NWPA, adverse impacts to the surface environment were prevented or minimized by implementing a variety of mitigative measures. For example, in preparation for the emergence in 1997 of the TBM as it completes the ESF tunnel, an area referred to as the South Portal was cleared, an access road was built, and the face of the mountain drilled and blasted at the exit point. Several steps have been taken to minimize the amounts of dust emitted by these activities and to prevent erosion from the site in the future. As the pad and road were prepared, topsoil was stripped and saved. A large tank was installed to provide water under pressure for purposes of cleaning newly exposed rock surfaces and spraying the surrounding area to suppress dust emissions. As both a safety and environmental precaution, the rock face of the tunnel exit is being meshed and grouted. Stored topsoil will be introduced to level the pad, followed by the emplacement of concrete sections on which the TBM will eventually be disassembled. Throughout the entire operation, water has been applied generously to exposed surfaces, and potentially useful topsoil has been preserved.

As in past years, preactivity surveys were conducted in 1996, water was applied to roads for dust suppression, and dust collection equipment was in place on drillrigs. Certain ecosystem studies were continued and, as surface-disturbing activities were completed in several areas, previously tested reclamation techniques were applied.

While the NWPA clearly states in Section 113 that no EIS is required to conduct site characterization studies, such a document is called for in Section 114 of the Act in the event that studies reveal that Yucca Mountain is suitable for development as a repository. In compliance with this requirement, the YMSCO initiated the EIS process, as prescribed by the National Environmental Policy Act (NEPA, 1969), in 1995 and pursued the effort in 1996 (Section 3.1.2 of this report). 


\subsubsection{National Environmental Policy Act (NEPA)}

Section 113 of the NWPA, entitled "Site Characterization," states that each activity carried out for purposes of evaluating the suitability of the Yucca Mountain site for development as a repository shall be considered a "preliminary decision-making activity." As such, no EIS, pursuant to Section 102(2)(C) of the NEPA, was required prior to initiating site characterization. Throughout characterization, however, the DOE is obliged to adhere to those sections of NEPA that pertain to overall protection of the environment and to the systematic interdisciplinary assessment of impacts of federal actions on the environment. The environmental program being carried out by the DOE (and described in sections $4.0,5.0$, and 6.0 of this document) is designed to satisfy those requirements of NEPA. Ultimately, should site characterization activities reveal that Yucca Mountain is suitable for a repository, the NEPA process (including the preparation of an EIS) will play an important role in the Secretary of Energy's recommendation of the site to the President (Section 114, NWPA).

In anticipation of the need for a Yucca Mountain EIS, the YMSCO published a Notice of Intent (NOI) in the Federal Register (FR) on August 7, 1995, stating its intention to prepare an EIS and to solicit public comments on the scope of the document. Fifteen scoping meetings were held, five in Nevada and the remainder as widespread as California and New York. Scoping concluded in December 1995. Approximately 1,000 public comment documents were submitted during the scoping period.

Budgetary restrictions resulted in the deferral of further EIS activities for the remainder of FY 1996. On October 1, 1996, EIS functions resumed with the DOE review of public scoping comments. Issuance of a public comment summary document is anticipated for May 1997. 


\subsubsection{Clean Air Act (CAA)}

The CAA is one of the statutes applicable to Yucca Mountain site characterization activities whose implementation and enforcement have been delegated to the State of Nevada by the Federal government. In part to comply with provisions of the CAA, the YMSCO established an extensive monitoring network to record meteorological conditions and to sample airborne particulate matter in the vicinity of the site. In addition, it was anticipated that the data to be acquired by such a monitoring network might be needed for future environmental analyses.

\subsubsection{Air Quality Permits}

An Air Quality Operating Permit is required for site characterization activities that are projected to disturb more than 8.1 hectares (ha [20 acres]) of land. The Operating Permit formerly held by the YMP for land disturbance was originally granted by the State of Nevada in 1991 as an Air Quality Permit to Construct. Effective July 1, 1994, the State changed its permitting process such that all new air quality permits are issued as Operating Permits, and

existing Permits to Construct, if renewed or revised, are reissued as Operating Permits. Another change, specific to the Yucca Mountain permit, occurred in mid-1995, when a number of existing permits for point sources of emissions and the surface disturbance permit were consolidated by the State into a single "generic" Air Quality Operating Permit (Table 3-2, p. 3-28). New or reissued air quality permits are subject to renewal five years after the date of issue.

In May of 1996, the State of Nevada removed the restriction from the Air Quality Operating Permit that established a maximum area of land that can be disturbed by YMP site characterization activities. Until then, the upper limit was 188.25 ha (465 acres) of land disturbed. Despite removal of this restriction, it is intended that the area disturbed each year will continue to be tracked and recorded by the YMSCO. In 1996, two survey methods were used, 
with data ultimately edited and analyzed in a geographic information system (GIS). Approximately 4.9 ha (12 acres) were disturbed by YMP activities during the year. Between June 21, 1991, and December 31, 1996, YMP activities disturbed approximately 115 ha (284 acres) of land. This number is less than that reported in the SER for CY 1995 because more accurate methods of estimating areas disturbed were used in 1996 to remeasure previously surveyed disturbances.

Both the previous and present permit conditions for surface disturbance stipulate that the DOE must sample ambient air for $\mathrm{PM}_{10}$ (i.e., inhalable particulate matter 10 micrometers or less in diameter) and monitor air temperature and wind during construction and for at least one year after construction is completed. Sampling for $\mathrm{PM}_{10}$ is conducted every sixth day for 24 consecutive hours at four locations. As of the end of 1996, particulate matter had been monitored for 80 months, and 22 quarterly Ambient Air Monitoring Reports had been submitted to the State, as required by the permit. During this period, the highest reported $\mathrm{PM}_{10}$ values were well below the ambient air quality standards, both for any single 24-hour period and for the average of all 24-hour periods (see Section 6.1.3, Air Quality).

Fugitive dust is also addressed in the original Air Quality Permit to Construct and in the recently modified Air Quality Operating Permit. The YMP is obliged to control fugitive dust by applying water or chemical stabilizers to disturbed areas, and by paving or graveling roads and parking areas. This mitigative use of water has been possible since 1992, when the Nevada State Engineer granted permission to the YMP to use NTS well J-13 water, primarily for dust suppression, subject to the conditions of the permit application and his approval. Since then, additional water appropriations-related permits have been issued, increasing groundwater appropriations and allowing flexibility in the choice of groundwater sources. Three temporary permits, received in June 1993 and extended in 1995, supplemented these appropriations, allowing the use of discharge water from the $\mathrm{C}$-well Complex for dust control, testing, or aquifer recharge (Section 3.1.15.1). In 1996, a Proof of Completion of Work was filed with the State for one of these wells, while one-year permit extensions were requested and received for the other 
two. Another permit, allowing use of water from well VH-1 for some of the same purposes, including dust control, was extended in May 1996.

On November 25, 1996, a revised Air Quality Operating Permit No. AP9611-0573 was received from the State. Revisions included changes requested by the YMSCO, as follows: (1) deletions from the permit of the grout batch plant, the CME 85 drill rig, and two Top Head Drive core drill rigs; and (2) reductions of annual operating hours for the LM 300 drill rig and the Atlas Copco air compressors. The grout batch plant and three drill rigs were considered expensive and no longer essential to the mission of the YMP. Reducing the hours of operation for the LM 300 and the air compressors contributes toward maintaining emissions at levels below the upper limits stipulated by the Class II Air Quality Operating Permit. Exceeding these emission limits would entail a lengthy application process for a new, upgraded permit, possibly delaying certain site characterization activities in the future.

Sixteen emission sources are presently authorized by the modified Air Quality Operating Permit and are listed in Table 3-2, (p. 3-28). A separate Air Quality Operating Permit, received in 1995 for a proposed facility to biologically remediate hydrocarbon-contaminated soil, was withdrawn in 1996 in favor of alternate and more cost-effective soil remediation methods. In summary, all known pollutant emissions are presently permitted by the Siate under the conditions of a single air quality permit.

An Annual Usage Report, summarizing 1996 information required by the air quality permit (e.g., types of equipment, quantities of emissions, hours of operation, etc.), was subnaitted to the Nevada Division of Environmental Protection (NDEP) in February 1997. Further, a thorough air quality emissions inventory was conducted in October 1996 to verify compliarice with CAA major source provisions. 


\subsubsection{Ozone-depleting Substances}

In response to legislation restricting the use of ozone-depleting substances, the YMSCO, in 1992, withdrew its request for permission to inject chlorofluorocarbons (CFCs) and hydrochlorofluorocarbons (HCFCs) into boreholes for the purposes of studying infiltration and groundwater flow (Section 3.1.5). Ozone-depleting substances that are prohibited under Title VI of the 1990 amendments to the CAA are not approved for use in any manner for Project activities.

\subsubsection{Clean Water Act (CWA)}

Many provisions of the CWA are not applicable to characterization of the Yucca Mountain site. Exceptions are requirements for a Section 404 permit from the U.S. Army Corps of Engineers (COE) and for National Pollutant Discharge Elimination System (NPDES) permits granted by the State of Nevada. With regard to the former, the COE determined in November of 1989 that rerouting washes for site characterization would require Section 404 permitting. In July of 1990, a Nationwide General Permit was issued by the COE, requiring a simple notification process when work entailing dredging, filling or modification of washes at the site was planned. In compliance with this permit, the DOE has notified the $\mathrm{COE}$, whenever appropriate, of plans to excavate sand and gravel for the construction of roads, drill pads, and ESF pads.

Prior to discharging effluents at Yucca Mountain, an approval to discharge, granted by the NDEP, is necessary for each type of discharge anticipated. The form of approval depends upon the effluent and circumstances involved. One possibility is an NPDES permit, as issued in May 1993 for stormwater discharge. Alternatively, the discharge may be included under the existing Underground Injection Control (UIC) Permit (Section 3.1.5), as with C-well pump test discharges, providing the State has been notified in advance. A third possibility for a potential 
discharge is inclusion under NDEP's statewide General Discharge Permit, as done in July 1995 for sewage disposal (i.e., approval to construct a septic tank/leach field facility).

\subsubsection{Safe Drinking Water Act (SDWA)}

The SDWA grants the EPA authority to regulate public drinking water supplies. The water supply for Yucca Mountain is considered a "public water supply," as defined by the SDWA, because it will service 15 or more connections or 25 people for more than 60 days per year. In 1978, the EPA approved Nevada's program for enforcing the drinking water standards established by the EPA. In response to an application filed by the YMSCO in May 1993, the Nevada Division of Health, in September 1993, issued a permit for construction of a waterdelivery system at Yucca Mountain. Construction of this system was completed in early 1996, with approval to operate the system granted by the State in April of that year.

Another component of the SDWA that is applicable to the YMP is the UIC Program, established to prevent contamination of underground sources of drinking water as a result of improper design, construction, and operation of injection wells. The State of Nevada also has EPA-granted authority to administer this program. Before tracers can be injected into drillholes or used in infiltration studies, a permit must be obtained from the State. In May of 1992, a permit was received allowing modification of the existing permit, granted in 1991, to conduct tests at the C-well Complex. The modified permit authorized the DOE to inject water and various tracers, including gas (but excluding ozone-depleting substances), into the three wells at the C-well site and into 50 other wells at Yucca Mountain.

In January 1996, the State finalized actions initiated earlier to modify the UIC permit (No. UNEV 89031). Included in the changes were an additional 50 boreholes for tracer injection and use of the following tracers: noble gases, sodium bromide, sodium iodide, potassium bromide, potassium iodide, sodium tungstate dihydrate, sodium molybdate dihydrate, 
sodium fluoride, fluorescein, potassium fluoride, magnesium iodide, and magnesium fluoride. Further, the modified permit consolidated other existing individual Project permits to include the following surface discharges: fire suppression pond (formerly the mine evaporation pond), concrete batch plant, infiltration basin, and water for dust suppression.

As required by the permit, an annual report was submitted to the State of Nevada in January 1996, with an updated status report filed each calendar quarter during the year.

\subsubsection{Endangered Species Act (ESA)}

A policy of the ESA is to ensure that no Federal agency authorizes, funds or carries out an action that jeopardizes the continued existence of an endangered or threatened species, or results in the destruction or adverse modification of the species' critical habitat. To date, the Mojave population of the desert tortoise (Gopherus agassizii), listed as threatened under the ESA, is the only species known to inhabit the Yucca Mountain site that receives full protection under the ESA. In early 1990, the USFWS rendered its Biological Opinion regarding the status of the tortoise at the site, relative to proposed site characterization activities (McNatt, 1990). Various restrictions to which the YMP must adhere were also outlined. Most of these restrictions were already being observed by the YMP.

Three ongoing activities represent compliance with the restrictions of the USFWS Biological Opinion (and, therefore, with the ESA). First, before any site characterization activity is undertaken, a team of trained biologists inspects the area of proposed activity for tortoises or evidence of their presence (burrows, scat, etc.). In addition, this preactivity survey is designed to detect potential adverse ecological impacts on tortoises. Recommendations to minimize activity impacts on the animals, their habitat, and on tortoise resoürces are made from the results of these surveys. Second, trained biologists inspect the proposed activity area every day on which ground-clearing activities occur, and survey in front of vehicles driving off-road to 
minimize the chance of harming tortoises. Results of these surveys are summarized in Section 6.1.1.4, Monitoring and Mitigation Program. Finally, all site workers must attend a General Employee Training (GET) session at which a film and viewgraphs accompany an in-class discussion that stresses the responsibility of YMP workers to protect the Yucca Mountain environment. One module of the presentation is devoted exclusively to biological resources, with considerable emphasis placed on protecting the desert tortoise. Each year after the initial training, workers must either attend the GET class or pass a multiple choice examination that demonstrates a continued understanding of their environmental obligations.

Also in compliance with the 1990 Biological Opinion, data collected from previous field studies of tortoises at Yucca Mountain were analyzed, and the results have been reported in four topical reports. Details of these reports and the tortoise study program are presented in Section. 6.1.1.2, Desert Tortoise Program.

\subsubsection{National Historic Preservation Act (NHPA) and Associated Cultural Resource Legislation Affecting Archaeology and Native Americans}

The NHPA is the principal authority to which the YMP must respond with regard to the protection of historic properties. Also included in the general category of cultural resource protection are the following: (1) Archaeological Resources Protection Act (ARPA); (2) Antiquities Act (AA); (3) American Indian Religious Freedom Act (AIRFA); and (4) the Native American Graves Protection and Repatriation Act (NAGPRA). The latter two laws also address cultural values and beliefs of the American Indian, and protect and preserve Native American religious rights and practices. The goal of all of these laws is to ensure that historic properties and cultural values are considered when Federal activities are to be undertaken; further, that every effort is expended to identify and mitigate any adverse effects on significant historic properties and matters of concern to Native Americans. The YMP area contains many historic sites and artifacts which require protection under these statutes. In addition, the rights of several 
Indian tribes and groups in the region, having traditional ties to the Yucca Mountain area, are protected by these laws.

Compliance with these acts is performed in accordance with a Programmatic Agreement for the Protection of Historical Properties, executed between the DOE and the Advisory Council on Historic Preservation (ACHP) in December of 1988. Implementation of the Programmatic Agreement (PA) satisfies the YMP's commitments and responsibilities under most of these various acts (the exception being NAGPRA). Stipulations of the PA include commitments by the DOE to (1) afford the Nevada State Historic Preservation Officer (SHPO) the opportunity to participate in monitoring compliance with the PA; (2) develop and implement a comprehensive research design for recovering, documenting, and interpreting data from historical properties in the region; (3) implement data recovery programs at affected historical properties; (4) train and inform workers of their responsibilities with respect to archaeological resources; (5) engage in consultations with identified Native American tribes and organizations regarding religious and cultural concerns about historical properties; and (6) provide the SHPO and the ACHP with regular reports concerning implementation of the $\mathrm{PA}$. The YMSCO has developed a program to comply with all stipulations of the PA.

Stipulation 1 of the PA requires that the SHPO be given the opportunity to participate in monitoring compliance with the PA. Although the SHPO is not signatory to the PA, the DOE has invited that agency to participate. To date, the SHPO has chosen not to do so. The DOE sends copies of all survey reports, data recovery plans, and annual reports to the SHPO for review and comment. The SHPO did not request to inspect the YMP area in 1996.

\subsubsection{Research and Data Recovery}

A number of other actions to implement the PA were carried out in 1996. A total of 11 archaeological preactivity surveys were conducted in areas proposed for Project activities, 
resulting in the identification of three new archaeological sites. Sixteen short reports (including five for surveys initiated the previous year) describing survey results were completed for submission by YMSCO to the ACHP and the Nevada SHPO. In addition, four other activities not requiring surveys or short reports were recommended for clearance.

Several activities were conducted to answer research questions identified in the Research Design and Data Recovery Plan for archaeological resources (DOE, 1990b). Studies included the continued development of a chronology of surface archaeological sites using obsidian hydration and thermoluminescence dating, caloric cost-benefit analyses of native plants of economic importance, dating of perishable artifacts found in the vicinity of Yucca Mountain, artifact movement studies, and functional analyses of various artifact classes collected as part of Project activities. A total of 45 known historical properties were revisited for purposes of periodically assessing their condition. All were in essentially the same condition as when discovered or last examined.

Because no data recovery projects were proposed for 1996, mitigative data recovery plans were not developed. However, the analysis and reporting of mitigative data recovery projects conducted during previous years was continued. Results of data recovery at two sites, $26 \mathrm{Ny} 1011$ and 26Ny8187, large lithic scatters located east and west of Yucca Mountain, respectively, are presently being compiled for evaluation.

Finally, a summary of all artifacts collected and processed during 1995 was completed in 1996. This listing updates the artifact inventory issued in 1992, which was provided to interested Native American groups. Both the 1992 and 1996 inventories were submitted to the Department of the Interior, in compliance with reporting requirements of the NAGPRA. All artifacts are maintained by the Desert Research Institute in a Las Vegas, Nevada, storage facility. 


\subsubsection{Educational Initiatives}

A program-wide worker education module stressing protection of archaeological and historic resources has been developed by the YMP as part of the comprehensive GET program (Section 4.2). All employees scheduled to work in the field must attend this course and pass an examination proving their understanding of their environmental responsibilities. Yearly refresher training is required thereafter. In 1996, 156 individuals attended initial GET training; another 357 fulfilled the requirements of annual GET refresher training.

The Project supplemented several educational displays to inform YMP workers and the general public about the YMP archaeological program and the kinds of historical properties present in the YMP region that are being protected. Items displayed include maps of southern Nevada depicting areas historically occupied by various Indian tribes, written recognition of local Native American individuals, projectiles and written explanations of their manufacture, examples of basket weaving and animal traps, traditional stories relating to certain plants and animals, and descriptions of plants as sources of food, clothing, medicine, and as religious objects.

Three such displays are located in the Yucca Mountain Science Centers in Las Vegas, Beatty, and Pahrump, visited by approximately 12,100 people in 1996 . Another display is located permanently in the Field Operations Center in Area 25 of the NTS for use during public tours of the Yucca Mountain site. A total of 2,520 people took part in 182 public tours in 1996. Finally, a portable display and slide show depicting archaeological and historical resources, and explaining the archaeological program, has been developed for other presentations by DOE personnel and support contractors.

Results of archaeological studies conducted at Yucca Mountain were presented at several professional meetings, including the annual meeting of the Society for American Archaeology. Results were subsequently submitted for publication in professional journals. 


\subsubsection{Native American Interactions}

The YMSCO continued consultations and interactions with involved Native Americian tribes in 1996, as directed by the AIRFA and the PA. Currently, the YMP Native American interaction program involves 17 tribes and organizations, and is comprised of Western Shoshone, Southern Paiute, and Owens Valley Paiute and Shoshone groups in Nevada, California, Utah, and Arizona. Two tribal update meetings, sponsored by the YMSCO, were held during the year: one in Mercury, Nevada, in May and the other in Las Vegas, Nevada, in November. Official Tribal Contact Representatives (OTCR) from each group were apprised of current cultural resources protection initiatives and the present status of site characterization activities. The OTCRs, organized as the Consolidated Group of Tribes and Organizations, drafted recommendations that were later forwarded to the DOE.

A recommendation made previously by the OTCRs and adopted by the YMSCO was to employ Native American monitors to accompany archaeological data recovery crews in the field. Their purpose was to ensure that Native American sensitivities are fully considered, especially during artifact collection. Because no data recovery projects were conducted during 1996, this Native American Monitor Program was not utilized.

Throughout 1996, the YMSCO sponsored the attendance of, or presentations by, DOE and/or Native American representatives at meetings with groups across the nation, including the National Congress of American Indians (NCAI). In addition, the DOE sponsored 47 speaking engagements and 42 educational forums at which the YMP Native American program was explained to the public. Mr. Richard Arnold, a Southern Paiute who serves as Director of the Las Vegas Indian Center in Las Vegas, supported the DOE in these presentations. 


\subsubsection{Comprehensive Environmental Response, Compensation and Liability Act (CERCLA)}

CERCLA requires that the National Response Center, administered by the U.S. Coast Guard, be contacted in the event of a release of a reportable quantity (RQ) of a hazardous material to the environment. No RQ releases under Section 103 of CERCLA occurred at Yucca Mountain in 1996, nor were there any Continuous Releases under Section 103 of CERCLA.

In 1986, CERCLA was reauthorized and amended by enactment of the Superfund Amendments and Reauthorization Act (SARA). Title III of SARA is known as the Emergency Planning and Community Right-to-Know Act (EPCRA), and is designed to ensure that the general public has access to information about chemicals present in their communities. The YMP is required by Executive Order $12856(E O, 1993)$ to comply with the reporting requirements of EPCRA and the Pollution Prevention Act (PPA) of 1990. The reportable chemicals differ for each section of EPCRA and include Hazardous Substances (HS), Extremely Hazardous Substances (EHS), hazardous chemicals for which Material Safety Data Sheets (MSDS) are necessary, and toxic chemicals listed under EPCRA Section 313. The YMSCO was not required to file an EPCRA 313 Report in 1996 because the quantities of listed toxic chemicals used by the YMP were insufficient to activate the reporting process. Further, none of these chemicals were released during the year. Nevertheless, to document this fact, a negative report was filed with the EPA.

The inventory of chemicals stored by the YMP in 1996 is reflected in certain other EPCRA reports to be submitted in March 1997. A Section 302 report must be filed when the quantity of an EHS, stored or used, exceeds the threshold planning quantity (TPQ) of 1000 pounds (lb). In 1996, the YMP had approximately 16,320 lb of the EHS, sulfuric acid, in use, most of it as an electrolyte in manufactured lead-acid batteries. The required Section 302 report

will be submitted to the Nevada State Emergency Response Commission and the Nye County Local Emergency Planning Committee in March 1997. (Similarly, a Section 302 report was submitted in March 1996 for chemicals stored by the YMP in 1995.) To further satisfy the 
reporting requirements of Section 302 and to fulfill those of Sections 311 and 312 of the EPCRA, the Hazardous Substances Information Facility Report will be prepared by YMSCO and submitted to the Office of the State Fire Marshal. This report serves as one component of the application to renew the annual Nevada Hazardous Material Storage Permit. In addition to the aforementioned sulfuric acid, the YMSCO will list, in its permit renewal request for CY 1997, several hazardous chemicals that were stored in 1996 in quantities that exceeded their prescribed reporting threshold of $10,000 \mathrm{lb}$ : propane, diesel fuel \#2, cement, kerosene, and lubricating and waste oils. During the year, no chemicals classified by the State of Nevada as highly hazardous were stored in quantities that exceeded their reporting thresholds.

\subsubsection{Resource Conservation and Recovery Act (RCRA)}

The management of hazardous wastes is regulated by the RCRA. The generation and management of YMP hazardous wastes is regulated under the Project-specific EPA Identification Number (ID) NV7890090023, granted by the EPA to the YMP. The intent of the Project is to minimize amounts of hazardous waste generated and accumulated on site to ensure that RCRA regulatory thresholds are not exceeded. All hazardous wastes are packaged, transported and disposed of off site in accordance with Federal and State requirements.

During 1996, six shipments of hazardous waste, totaling $1,860 \mathrm{~kg}(4,100 \mathrm{lb})$, were transported to EPA-permitted treatment, storage and disposal (TSD) facilities. Wastes consisted of the following: non-empty/non-working aerosol cans, lead-contaminated soil, isoparafinnic hydrocarbons, lithium batteries, waste paints, flammable liquids, poisonous liquids, ammonia solution, combustible liquids, toluene diisocyanate (resin), chloroform, formaldehyde solution, and various other hazardous wastes, both liquid and solid. 


\subsubsection{Federal Land Policy and Management Act (FLPMA)}

Federal projects requiring access to, and activity on, public lands require compliance with the FLPMA. Because Yucca Mountain is partially on BLM-administered public land and USAF-administered BLM land, YMP site characterization activities must comply with BLM requirements for access and use. Access to these areas for purposes of site characterization was granted in two major ROWRs issued in January 1988 and October 1989. The latter ROWR was renewed by the BLM in June 1994.

Many smaller ROWRs are granted each year for site characterization activities that may range in size from a single radiological dosimeter mounted on a post to an off-site trench or surface water monitoring station. Again in 1996, several ROWRs for activities in this size class (usually requiring less than 0.124 ha [0.05 acre]) were issued by the BLM. The DOE complied with all environmental actions stipulated in the ROWRs.

Since 1990, the BLM has issued three free-use permits to excavate sand and gravel for use in constructing roads and drillpads. No applications for free-use permits were filed in 1996. Annual reports for the three existing permits were submitted to the BLM during 1996.

\subsubsection{Farmland Protection Policy Act (FPPA)}

The FPPA requires that the DOE determine whether the potential exists for site characterization to affect land designated as either prime or unique, or farmlands of State or local importance. In 1988, the Soil Conservation Service (since renamed the Natural Resource Conservation Service) confirmed that no such land will be disturbed by site characterization activities. No further compliance measures were necessary in 1996. 
NOTE: Two major federal environmental statutes not discussed in this Compliance: Summary are the Toxic Substances Control Act (TSCA) and the Federal Insecticide; Fungicide and Rodenticide Act (FIFRA). Neither is applicable to current Yucca Mountain site characterization activities.

\subsubsection{Executive Order (EO) 11988, Floodplain Management}

The DOE's implementation of EO 11988 extends to the normally dry washes of the Yucca Mountain site. If proposed activities within the 100-year floodplain are anticipated, a notice of the proposed action must be published in the FR, and alternatives to the proposed locations must be evaluated in a floodplain assessment. On February 9, 1989, a Notice of Floodplain/Wetlands Involvement was published for the YMP in the FR (54 FR 6318) followed, in August 1991, by issuance of a floodplain assessment of surface-based investigations (DOE, 1991). On October 1, 1991, a Floodplain Statement of Findings appeared in the FR (56 FR 49765). A companion assessment, examining the potential effects of ESF activities and cumulative impacts of ESF and surface-based activities combined, was issued in October 1992 (DOE, 1992a). No further action was required in 1996.

\subsubsection{Executive Order (EO) 11990, Protection of Wetlands}

Wetlands are not discussed in this SER because none exist at or near Yucca Mountain. The USFWS has declared that "... site characterization activities should not affect any wetlands on or near the Yucca Mountain site" (Navarre, 1988). 


\subsubsection{DOE Orders}

The DOE, the EPA, and the Nuclear Regulatory Commission (NRC) have each established rules, regulations, and orders that pertain to radiological effects on health, safety, and the environment. The orders and regulations that most apply to site characterization are those emanating from the DOE. Regulations issued by the EPA and the NRC apply, for the most part, to repository construction, operation, closure, and decommissioning. Collectively, however, these regulations represent a continuum of rules and standards that begin with the DOE Orders, and mandate that the DOE initiate and continue radiological monitoring activities at Yucca Mountain throughout the duration of the YMP.

DOE Orders that apply, to a greater or lesser extent, to radiological matters during site characterization are the following, as stipulated in the Environmental Regulatory Compliance Plan (ERCP) (DOE, 1996b): 5400.1, General Environmental Protection Program, to be superseded by DOE Order 231.1 (under review in 1996); 5400.5, Radiation Protection of the Public and the Environment; 251.4, which canceled 5480.1B, Environment, Safety and Health Program for Department of Energy Operations; 5480.4, Environmental Protection, Safety and Health Protection Standards; and 5484.1, Environmental Protection, Safety, and Health Protection Information Reporting Requirements. DOE Order 5480.11, Radiation Protection for Occupational Workers was replaced, effective December 30, 1995, by 10 CFR 835 , Occupational Radiation Protection.

The YMP radiological monitoring activities conducted in 1996 focused on ambient radiation and air as a carrier of radioactive particles and gas. While a circular radiological study area $80 \mathrm{~km}(50 \mathrm{mi})$ in radius is required by DOE and NRC guidelines, the study area at Yucca Mountain was extended to $84 \mathrm{~km}(52 \mathrm{mi})$ to include the town of Pahrump. The study circle consists of a near-field area within a 16-km (10-mi) radius of Yucca Mountain and a far-field area between the 16- and $84-\mathrm{km}$ (10- to 52-mi) boundaries. The locations of YMP radiological 
monitoring sites in the near-field area are represented in Figure 3-1. No radiological monitoring sites have been operated in the far-field area since the beginning of FY 1996 (October 1, 1995).

The monitoring regimen during 1996 was as follows: 40 thermoluminescent dosimeters (TLD, typically two units per station) monitored quarterly; two pressurized ionization chambers (PIC) recording data continuously at two sites; 18 electret ionization chamber. (EIC) readings taken monthly at 18 sites; two continuous radon monitor (CRM) readings recorded at two locations; and samples obtained weekly from continuous air samplers (CAS) at five locations. A synopsis of the monitoring regimen for the year is given in Table 5-1 (p. 5-2).

Monitoring was also performed to determine the extent of resuspension of existing radioactive material by casual traffic and/or wind. Due to the history of nuclear development and testing projects conducted in the general vicinity of Yucca Mountain, all areas proposed for surface-disturbing activities within the NTS boundary were investigated for the presence of radionuclides (i.e., radiological preactivity surveys were conducted).

\subsubsection{Nevada Law}

\subsubsection{Water}

On June 28, 1993, the Nevada State Engineer issued Temporary Water Appropriation Permits for three boreholes that comprise the C-well Complex. Since then, these wells have been used to conduct aquifer characteristics studies as part of the YMP site characterization program. The permits allow the discharge from the three wells to be put to beneficial use to include dust control, testing, or transfer to a spreading basin for aquifer recharge. In March 1995 , these permits were renewed by the State Engineer. 

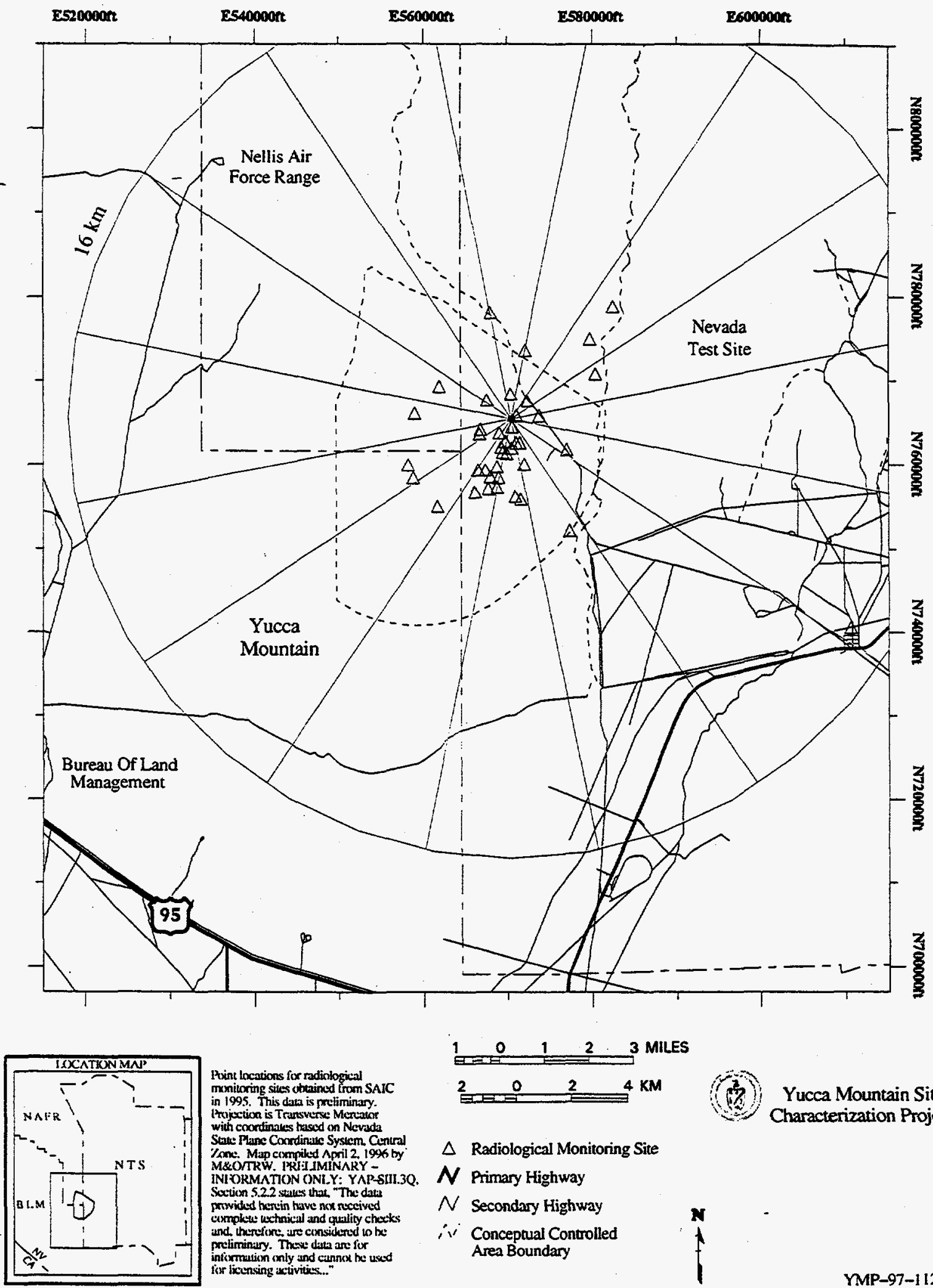

Pxint locations for radiologienal
menitoring sites obtained from SAIC monitoring sites obtained from SAIC
in 1995. This data is pretiminary. Itrojoction is Transwerse Mercator with coordinales hased on Nevada Jone. Map ccrmpiled April 2, 1996 by INIORMATION ONLYY: YAP-SIII.3O. Sertion 5.22 stentes thex. "The datis

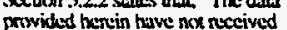
complete urchnical and guality cheots and therefore, ure considered to be:

pretiminary. Thew data ane for

intixrmation conly and cinnex to useod for likensing activities..."

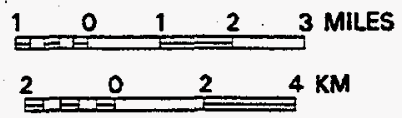

$\triangle$ Radiological Monitoring Site

$\mathcal{N}$ Primary Highway

$N$ Secondary Highway

$\therefore$ Conceptual Controlled Area Boundary

Figure 3-1. Near-field Radiological Monitoring Sites 
In 1996, permits for two of the wells were extended for another year. An extension of the third permit was not needed, and a Proof of Completion of Work at that well was filed with the State. Another permit, allowing use of water from well VH-1 for some of the same purposes including dust control, was extended in May 1996.

\subsubsection{Hazardous Materials}

Nevada Administrative Code (NAC) 445A.345-.348 requires notification of the State in instances of releases involving specified quantities of pollutants. The Division of Emergency Management must be notified as soon as possible in the event of a hazardous material/waste release, and the NDEP is to be notified as soon as possible after the release, but no later than the end of the first working day after the release. Although petroleum products are not considered hazardous by the State of Nevada, a report is required by the State for any release onto a land surface of a petroleum product that exceeds 95 liters or 25 gallons (gal), or that contaminates at least 2.3 cubic meters $\left(\mathrm{m}^{3}\right)$ or 3 cubic yards $\left(\mathrm{yd}^{3}\right)$ of soil at a concentration greater than 100 micrograms per kilogram $(\mu \mathrm{g} / \mathrm{kg})$.

The YMP is complying with these regulations in its response to oil and chemical spills at the site (Section 6.2). In all instances, reporting requirements are being met, and contaminated soils are being excavated for authorized off-site treatment and recycling of treated soils.

The Hazardous Material Storage Permit was renewed in 1996 by the Nevada State Fire Marshal Division. Required at Yucca Mountain primarily for the storage of flammable construction materials, this permit must be renewed annually. 


\subsubsection{Environmental, Safety, and Health Assessments}

The primary objective of the YMP Environmental, Safety, and Health (ES\&H) assessment program is to verify that all Project-related activities are managed and performed in compliance with Federal, State, and local regulations, DOE Orders and management objectives, YMP plans and procedures, and permit stipulations. Specifically, Titles 10 (Energy), 29 (Labor), 40 (Protection of Environment), and 49 (Transportation) of the Code of Federal Regulations (CFR), and DOE Orders on Occupational Safety and Health, as well as Environmental Protection, contain requirements for audits/assessments/inspections of various ES\&H program elements.

One of the principal means by which the YMSCO and Civilian Radioactive Waste Management System Management and Operating Contractor (CRWMS M\&O) pursue the objective of full regulatory compliance is through their respective ES\&H assessments of Project activities. Project assessments are performed for the Assistant Manager for Environmental, Safety, and Health (AMESH) by the CRWMS M\&O Environmental, Safety, and Health Compliance Department (ESHCD). The CRWMS M\&O ESHCD also performs internal M\&O assessments. Assessments of quality-affecting environmental data collection programs are conducted by the Quality Assurance Technical Support Services (QATSS).

Both comprehensive and focused, special-issue ES\&H assessments evaluate Project organizations, programs, activities, and related support functions. Comprehensive assessments evaluate a broad range of environmental, safety, and health topics in a specific organization or Project-wide program. Focused, special-issue assessments, by contrast, examine a particular program element, potential noncompliance condition, or specific area of concern that is time-sensitive or that requires immediate attention. Five comprehensive assessments and eight focused, special-issue assessments were completed in 1996. 
The ES\&H assessment function also includes ongoing regulatory review and analysis of Federal Registers, CFRs, DOE Orders, and other resources to keep Project personnel abreast: of contemporary ES\&H information and/or new or changing ES\&H regulatory requirements applicable to YMP activities. Information from these reviews is posted on the Project-wide ES\&H Notifications database, and quarterly summaries are provided to the AMESH. Project documents and reports are also reviewed for ES\&H compliance requirements. During 1996, results of 167 regulatory reviews/analyses were posted on the ES\&H Notifications database, and 93 Project documents were reviewed for ES\&H compliance. New ES\&H regulatory requirements identified during these reviews that are applicable to YMP activities may be included in subsequent comprehensive or focused, special-issue assessments.

\subsubsection{Environmental Surveillance Program}

The environmental surveillance program is another means by which compliance with environmental requirements during the performance of YMP activities is measured. Surveillances are conducted by the CRWMS M\&O Environmental Programs Department (EPD) to confirm that YMP activities are being planned, managed, and operated in a manner that will protect and maintain environmental quality, minimize potential threats to the environment, and comply with applicable Project programmatic requirements. The EPD conducted 282 environmental surveillances in 1996 (Section 4.4).

\subsection{SUMMARY OF PERMITS AND COMPLIANCE ACTIONS}

Tables 3-1, 3-2, and 3-3 list the permits currently required to conduct site characterization activities at Yucca Mountain. In addition, the current status of each permit and its applicability to a specific YMP activity is presented. 
During 1996, two incidents occurred which raised concerns within the YMSCO that conditions of the UIC permit may have been violated. In both instances, the State of Nevada was notified as soon as the DOE was made aware that a potential problem existed. Upon investigation, the State declared that only one of the incidents represented a violation (which was resolved and closed within 16 days of issuance of the Finding of Violation and Order) of the UIC permit. The second event was ruled an unavoidable equipment failure involving no violation of permit conditions.

Specifically, the YMSCO became aware of the first incident on July 22, 1996, while preparing the quarterly UIC report for submission to the NDEP. The UIC permit allows the introduction of no more than 30 parts per million ( $\mathrm{ppm}$ ) of the tracer, sulfur hexafluoride $\left(\mathrm{SF}_{6}\right)$, to a borehole at any one time to measure diffusion of $\mathrm{SF}_{6}$ gas through the surrounding rock. On six occasions between June 26 and July 11, 1996, this limit was exceeded. Inquiry into the circumstances involved indicated that permit injection requirements were misunderstood by the investigator responsible for conducting the tracer tests.

Conditions of the test and the distance to the nearest groundwater $(600 \mathrm{ft}$ below the test location) suggested that the excessive concentrations of $\mathrm{SF}_{6}$ would not have adversely affected the environment. Further, the solubility of $\mathrm{SF}_{6}$ in water is negligible, and the compound is not regulated as an HS under CERCLA or an EHS under EPCRA. Nevertheless, a finding of Alleged Violation and Order was issued by the NDEP on August 26, 1996. Following review of the YMSCO responses to the administrative Order, the State declared on September 11, 1996 , that the DOE was in "substantial compliance" with terms and conditions of the Order and that civil penalties were not appropriate. The State declared the case closed.

The second incident also involved the release of excessive amounts of $\mathrm{SF}_{6}$ underground and was detected on December 9, 1996, during routine gas sampling of a drill hole. A review of the potential causes of this event revealed that the release probably occurred on October 31 , 1996, the final day of dry drilling in this hole. On April 25, 1997, the NDEP issued their 
findings that (1) the incident was isolated and probably due to equipment failure; (2) no impact to groundwater or the environment was reported; (3) the DOE had reported the incident in a timely manner; and (4) the State would take no action against the DOE in this matter.

\subsection{PERMIT-ASSOCIATED LITIGATION}

No court action was undertaken in 1996 by either the DOE or the State of Nevada. 
TABLE 3-1. PERMITTING APPLICABLE TO SITE CHARACTERIZATION ACTIVITIES (FEDERAL)

\begin{tabular}{|c|c|c|c|c|c|c|}
\hline REGULATION & PERMIT & AGENCY & (1, 14, APPLICABILITY & FILED & $\begin{array}{l}\text { EXPECTED(E) } / \\
\text { ACTUAL }\end{array}$ & $\begin{array}{l}\text { STATUS/EXPIRATION } \\
\text { DATE }\end{array}$ \\
\hline \multirow[t]{2}{*}{$\begin{array}{l}\text { Federal Land Policy } \\
\text { \& Management Act }\end{array}$} & Free Use Permit & BLM & $\begin{array}{l}\text { Needed for excavation of sand and gravel } \\
\text { from public lands. Includes NTS land, } \\
\text { additional gravel needed for construction of } \\
\text { roads, drill pads, ESF pads. } \\
\text { - Drillhole Wash Pit } \\
\text { - 40 Mile Wash Pit } \\
\text { - Borrow Pit \#1 }\end{array}$ & $\begin{array}{l}07 / 15 / 89 \\
01 / 28 / 92 \\
08 / 28 / 92 \\
\end{array}$ & $\begin{array}{l}10 / 26 / 90 \\
05 / 20 / 92 \\
01 / 08 / 93 \\
\end{array}$ & $\begin{array}{l}\text { - Expires when construction ends } \\
\text { - Expires } 01 / 06 / 01 \\
\text { - Expires } 01 / 06 / 01\end{array}$ \\
\hline & Right-of-Way Reservations & $\begin{array}{l}\text { BLM } \\
\text { BLM/USAF }\end{array}$ & $\begin{array}{l}\text { Needed for access to public and Air Force } \\
\text { land }\end{array}$ & $\begin{array}{l}11 / 23 / 87 \\
10 / 23 / 87\end{array}$ & $\begin{array}{c}01 / 06 / 88 \\
10 / 10 / 89 \\
\text { effective } 7 / 1 / 94 \\
\end{array}$ & $\begin{array}{l}\text { - Expires 01/06/01 } \\
\text { - Expires 01/06/01 }\end{array}$ \\
\hline Endangered Species Act & $\begin{array}{l}\text { Endangered Species Act } \\
\text { Compliance }\end{array}$ & USFWS & $\begin{array}{l}\text { Needed if endangered species is potentially } \\
\text { affected (e.g., desert tortoise). Each } \\
\text { activity location must be surveyed prior to } \\
\text { disturbance. }\end{array}$ & $10 / 10 / 89$ & $\begin{array}{c}05 / 30 / 97(\mathrm{E}) \\
08 / 20 / 97\end{array}$ & $\begin{array}{l}\text { - New Biological Opinion expected } \\
\text { - Amendment to State animal } \\
\text { handling permits issued }\end{array}$ \\
\hline $\begin{array}{l}\text { Executive Order } \\
11988 \text { (10 CFR 1022) }\end{array}$ & $\begin{array}{l}\text { Floodplain Assessment and } \\
\text { Federal Register Notice }\end{array}$ & DOE/EH & $\begin{array}{l}\text { Needed before construction in a floodplain } \\
(100-\mathrm{Yr}) \text {. EH-1 reviews/approves } \\
\text { assessment. Must be published in Federal } \\
\text { Register. }\end{array}$ & $05 / 15 / 92$ & $\begin{array}{l}10 / 01 / 91 \\
10 / 23 / 92\end{array}$ & $\begin{array}{l}\text { - SBT Assessment and Statement of } \\
\text { Findings issued } \\
\text { - ESF Assessment and Statement of } \\
\text { Findings issued }\end{array}$ \\
\hline Clean Water Act & $\begin{array}{l}\text { Nationwide General } \\
\text { Permit (Section 404) }\end{array}$ & $\mathrm{COE}$ & $\begin{array}{l}\text { Needed before constructing in a water } \\
\text { course }\end{array}$ & $04 / 28 / 89$ & $\begin{array}{l}07 / 17 / 90 \\
10 / 15 / 92 \\
\end{array}$ & $\begin{array}{l}\text { - No expiration date } \\
\text { - Notified COE of start of ESF }\end{array}$ \\
\hline $\begin{array}{l}\text { National Historic } \\
\text { Preservation Act } \\
\text { Archaeological } \\
\text { Resources Protection Act } \\
\text { American Indian } \\
\text { Religious Freedom Act }\end{array}$ & Programmatic Agreement & ACHP & $\begin{array}{l}\text { Cultural properties must be protected. } \\
\text { Each activity location must be surveyed } \\
\text { prior to disturbance. }\end{array}$ & $12 / 01 / 86$ & $12 / 22 / 88$ & $\begin{array}{l}\text { - PA completed } \\
\text { - Compliance with PA satisfies } \\
\text { regulatory requirements }\end{array}$ \\
\hline $\begin{array}{l}\text { Farmland Protection Policy } \\
\text { Act }\end{array}$ & $\begin{array}{l}\text { Prime Farmland } \\
\text { Consultation }\end{array}$ & NRCS & $\begin{array}{l}\text { Needed to ensure no impact to prime } \\
\text { farmland }\end{array}$ & $02 / 11 / 88$ & $03 / 01 / 88$ & - Consultation completed \\
\hline
\end{tabular}


TABLE 3-2. PERMITTING APPLICABLE TO SITE CHARACTERIZATION ACTIVITIES (FEDERAL FLOWDOWN)

\begin{tabular}{|c|c|c|c|c|c|c|}
\hline REGULATION & $14 \%$ PERMIT & AGENCY & \& & FILED & $\begin{array}{l}\text { EXPECTED (E) } / \\
\text { ACTUAL }\end{array}$ & STATUS/EXPIRATION DATE \\
\hline Clean Air Act & Air Quality Operating Permit & NDEP & $\begin{array}{l}\text { Required for disturbance of }>20 \text { acres and for } \\
\text { point sources of emissions: } \\
\text { (System \#1) Borrow Screen } \\
\text { (2) Kolberg Screening Plant and Conveyors } \\
\text { (3) LM-300 Drillrig } \\
\text { (4) Failing Drillrig } \\
(5) \quad \text { CME } 850 \text { Drillrig } \\
(6) \quad \text { Cummins Engine, } 600 \mathrm{HP} \\
\text { (7,8) Air Compressors } \\
(9) \text { CME 550 Drillrig } \\
\text { (10) Joy 1 Drillig } \\
\text { (11) } \text { Stratmaster Drillrig } \\
\text { (12) Concrete Batch Plant } \\
\text { (13) Radial Stack Conveyor } \\
\text { (14) Wilson Drillrig } \\
\text { (15) ESF Conveyor System } \\
\text { (16) Diesel Engines for 500 KW Generator } \\
\end{array}$ & $\begin{array}{l}\text { N/A } \\
\text { (See note } \\
\text { under } \\
\text { Status) }\end{array}$ & $\begin{array}{l}\text { Revised } 11 / 25 / 95 \\
\text { and } 11 / 25 / 96\end{array}$ & $\begin{array}{l}\text { - Permit No. } 9999-0076 \text { (for surface } \\
\text { disturbance) superseded by permit } \\
\text { below } \\
\text { - Each of these point sources was } \\
\text { originally assigned its own permit. } \\
\text { In } 1995 \text {, the State of Nevada } \\
\text { included all under Permit No. } \\
\text { AP9611-0573, with an expiration } \\
\text { date of April 26, 2000. Permit } \\
\text { revisions were received from the } \\
\text { State on November } 25,1996 \text { (see } \\
\text { Section 3.1.3, this report). }\end{array}$ \\
\hline \multirow[t]{2}{*}{$\begin{array}{l}\text { Safe Drinking Water } \\
\text { Act }\end{array}$} & $\begin{array}{l}\text { Underground Injection } \\
\text { Control Permit }\end{array}$ & NDEP & $\begin{array}{ll}- & \text { C-Well Complex and Drillholes (103) } \\
- & \text { C-Well Pump Tests } \\
- & \text { Tracers } \\
- & \text { Fire Suppression Pond } \\
\end{array}$ & $\begin{array}{l}05 / 18 / 95 \\
07 / 19 / 95\end{array}$ & $\begin{array}{l}01 / 30 / 96 \\
01 / 30 / 96 \\
01 / 30 / 96 \\
01 / 30 / 96 \\
\end{array}$ & $\begin{array}{l}\text { Original UIC Permit No. } \\
\text { UNEV } 89031 \text { modified again in } \\
1996 \text { to include all UIC entries }\end{array}$ \\
\hline & Public Water System Permit & NDEP & $\begin{array}{l}\text { Needed before construction begins on the } \\
\text { system }\end{array}$ & $05 / 18 / 93$ & $\begin{array}{l}04 / 25 / 96 \\
06 / 11 / 96\end{array}$ & $\begin{array}{ll}\text { - } & \text { State verbal approval to operate } \\
\text { - } & \text { Permit received; expires } 9 / 30 / 97\end{array}$ \\
\hline $\begin{array}{l}\text { Resource } \\
\text { Conservation and } \\
\text { Recovery Act }\end{array}$ & $\begin{array}{l}\text { ' RCRA EPA Registration } \\
\text { and ID Number }\end{array}$ & NDEP & $\begin{array}{l}\text { Needed before generating regulated quantities } \\
\text { of hazardous waste }\end{array}$ & $04 / 01 / 89$ & $06 / 26 / 89$ & - ID Number received \\
\hline Clean Water Act & $\begin{array}{l}\text { General Discharge Permit; } \\
\text { NPDES }\end{array}$ & NDEP & $\begin{array}{l}\text { Needed prior to discharging effluent } \\
\text { - } \quad \text { Stormwater } \\
\text { - } \quad \text { Septic Tank/Leach Field } \\
\end{array}$ & $\begin{array}{l}09 / 08 / 92 \\
03 / 15 / 95 \\
\end{array}$ & $\begin{array}{l}05 / 14 / 93 \\
07 / 12 / 95 \\
\end{array}$ & $\begin{array}{ll}- & \text { Expires 05/14/98 } \\
- & \text { Permit expires 05/12/98 } \\
\end{array}$ \\
\hline
\end{tabular}


TABLE 3-3. PERMITTING APPLICABLE TO SITE CHARACTERIZATION ACTIVITIES (STATE)

\begin{tabular}{|c|c|c|c|c|c|c|}
\hline REGULATION & PERMIT & AGENCY & APPLICABILITY & FILED & $\begin{array}{l}\text { EXPECTED (E)/ } \\
\text { ACTUAL }\end{array}$ & STATUS/EXPLRATION DATE \\
\hline \multirow[t]{2}{*}{ Nevada Law } & Groundwater Appropriation & NSE & $\begin{array}{l}\text { Needed for use of water } \\
\text { - Well J-13 } \\
\text { - Additional request } \\
\text { - Well VH-1 } \\
\text { - Well VH-1 Extension } \\
\text { - C-Well Complex (3) } \\
\text { - Well JF-3 } \\
\text { - Hole UZ-16 } \\
\text { - Hole UZ-14 } \\
\text { - Holes USW-G2, SRG-5/SD-11, SD-12 } \\
\text { - Holes WT-1, WT-10, WT-12, WT-13, WT-17, } \\
\text { WT-24 } \\
\end{array}$ & $\begin{array}{c}07 / 12 / 88 \\
04 / 02 / 92 \\
03 / 20 / 92 \\
-- \\
05 / 11 / 93 \\
10 / 10 / 91 \\
12 / 11 / 91 \\
02 / 26 / 93 \\
-- \\
--\end{array}$ & $\begin{array}{l}03 / 02 / 92 \\
08 / 18 / 92 \\
05 / 18 / 92 \\
05 / 15 / 96 \\
06 / 28 / 93 \\
10 / 24 / 91 \\
12 / 07 / 92 \\
03 / 17 / 93 \\
. . \\
12 / 27 / 93\end{array}$ & $\begin{array}{l}\text { Expires } 03 / 02 / 02 \\
\text { Expires } 04 / 09 / 02 \\
\text { Expires } 04 / 09 / 02 \\
\text { Expires } 04 / 09 / 97 \\
\text { Extended } 03 / 07 / 95 \text {; expires } 12 / 31 / 98 \\
\text { Renewal not required } \\
\text { Renewal not required } \\
\text { Extended indefinitely } \\
\text { Extended indefinitely } \\
\text { Waivers received }\end{array}$ \\
\hline & $\begin{array}{l}\text { Hazardous Material Storage } \\
\text { Permit }\end{array}$ & NFMD & Needed for storage of flammable materials &.. & $02 / 29 / 96$ & Expires 12/31/96. Renewed annually. \\
\hline
\end{tabular}

LEGEND

NDEP Nevada Division of Environmental Protection

NFMD Nevada Fire Marshal Division

NSE Nevada State Engineer

BLM Bureau of Land Management

USFWS U.S. Fish and Wildlife Service

COE Corps of Engineers

USAF U.S. Air Force

ACHP Advisory Council on Historic Preservation
NRCS Natural Resource Conservation Service

DOE/EH Department of Energy/Office of Environment, Safety, and Health

EPA Environmental Protection Agency

SBT Surface-based Testing

ESF Exploratory Studies Facility

NPDES National Pollutant Discharge Elimination System

PA Programmatic Agreement

RCRA Resource Conservation and Recovery Act 


\subsection{ENVIRONMENTAL PROGRAM INFORMATION}

\subsection{WASTE MINIMIZATION}

Waste minimization is a fundamental concept in protecting the environment, and the YMSCO stresses the avoidance of waste generation. Personnel are encouraged to reduce the amount of waste generated by employing waste minimization and pollution prevention in their day-to-day operations. Recycling is also encouraged and routinely practiced.

A principle component of the YMP waste minimization program is the Request for Authorization (RFA) to use regulated materials. This review and approval process was developed to control the purchase, storage, and use by the YMP of products having the potential to adversely affect the environment. The RFA process and other aspects of the program are designed to (1) obtain accurate and current information on materials handled, waste stream generation, and waste management costs; (2) create an organization comprised of DOE and CRWMS M\&O representatives to develop and administer the waste minimization program; (3) define sources of waste to be reduced; and (4) develop a method of tracking the performance and progress of the program. Achievement of these goals was documented in 1994 in the Annual Report on Waste Generation and Pollution Prevention Progress, submitted by the YMSCO to DOE Headquarters. It has since been determined that the amount of waste generated annually by the YMP has been well below reporting thresholds established by DOE Headquarters. Consequently, in both 1995 and 1996, the YMP has been exempt from this reporting requirement.

The YMSCO issued the Waste Minimization and Pollution Prevention Awareness Plan in June 1995 (DOE, 1995b). This plan established specific goals for the program in 1995 and 1996, among which were increased recycling efforts. Waste management activities, both at the YMP site and at support facilities in Las Vegas, accumulated considerable amounts of recyclable materials in 1996, including the following: paper (302 tons), note pads (1,250 lb), used notebook 
binders ( 4,453 binders, given to local school districts), toner cartridges (608), cardboard $(3,980 \mathrm{lb}$ ), and aluminum cans $(940 \mathrm{lb})$. A single recycling event at the YMP site in August 1996 resulted in the accumulation of approximately 35 tons of recyclable scrap metal.

Several other items recycled by the YMP were, for the most part, collected following mechanical maintenance performed at the ESF. Among these were 46 tons of lead-acid batteries and 32 tires. Used oils, following tests to ensure that chlorinated solvents were not present, were sent off site for recycling (3,500 gal). Approximately $300 \mathrm{gal}$ of this total consisted of oil recovered by processing oily water (construction waste water and rain runoff) through an oilwater separator that became operational in 1996. The remaining aqueous portion, presently allowed to evaporate, will most likely be used for dust suppression once permission has been granted by the State of Nevada. Antifreeze coolants ( 260 gal) were also recycled. Finally, under terms of a contract approved by the YMSCO in 1996, 110 gal of used cleaning solvent were transported to a recycling facility. The solvent used by the YMP was selected because it lacks hazardous waste listed and characteristic components, as defined by RCRA.

\subsection{TRAINING}

Worker environmental awareness and pollution prevention are major components of the YMP environmental compliance effort. A formal YMP environmental training program, which includes waste minimization and pollution prevention awareness, comprises a portion of the Project's General Employee Training (GET) program. In 1996, 156 individuals attended GET, with a cumulative total of 3,691 trained since the beginning of the Project. All employees who work in the field are required to take this course prior to being granted unescorted access to the site. In addition, the GET program requires participation in annual refresher training attended by 357 Project employees in 1996. 
Employees who enter the Project site and routinely work with radiological materials are required to attend a radiological protection training program. This program is based on a graded approach to the hazards likely to be encountered by the employees. Three classes comprise the program: General Employee Radiation Training (GERT), Radiation Worker I (RW I) Training, and Radiation Control Technician (RCT) Training.

The YMP hazardous materials management program requires that each CRWMS M\&O organization provide special training for those whose work involves facility waste minimization, handling and disposal of hazardous materials, and actions and reporting required in the event of hazardous material spills or occurrences. These programs are taught or approved by the M\&O Training Department.

\subsection{ENVIRONMENTAL, SAFETY, AND HEALTH ASSESSMENT PROGRAM}

The ES\&H assessment program provides programmatic oversight of YMP activities in support of the broader goal of achieving full compliance and excellence in the ES\&H area. This is accomplished through evaluation of YMP ES\&H activities and programs for compliance with Federal, state, and local regulations, DOE Orders, permit stipulations, and YMP and CRWMS $\mathrm{M} \& \mathrm{O}$ plans/policies/procedures. As a result, the assessment process, to include verification and closure of improvement actions, continues to enhance the effectiveness and implementation of ES\&H roles and responsibilities among the CRWMS M\&O contractors, subcontractors, and the U.S. Geological Survey (USGS).

The YMSCO AMESH and CRWMS M\&O Environmental, Safety, and Health Compliance Department (ESHCD) conduct ES\&H assessments of the YMP/M\&O organizations, programs, and activities, in accordance with requirements outlined in the ERCP (DOE, 1996b) and YAP-30.16, Environmental Assessment and Surveillance of Yucca Mountain Site Characterization Project Activities. During 1996, five comprehensive assessments and eight 
special-issue assessments were conducted by the ESHCD. The five comprehensive assessments were conducted by a team of ES\&H technical specialists and included evaluation of four Projectwide ES\&H programs and one internal organization ES\&H program.

Focused, special-issue assessments are more limited in scope and duration and are conducted to provide a "quick response" assessment of high-interest ES\&H compliance or management topics. They are usually performed by one assessor with assistance from other technical specialists, as necessary, to ensure a thorough assessment of a function or issue. Such topics have generally included a specific regulatory requirement, new YMP activities or support functions, or common elements that bridge YMP organizational areas of responsibility. Focused, special-issue assessments conducted during 1996 evaluated management of hazardous waste accumulation areas, ES\&H compliance surveillance tracking, regulatory facility signage requirements, motor vehicle safety, protection of open trenches and excavations, lockout/tagout procedures and practices, the Stormwater Pollution Prevention Plan, and electrical equipment grounding. Table 4-1 summarizes improvements resulting from focused assessments (FY 96-1 through 96-10) and comprehensive assessments (FY 96B through 97B) in 1996. (Note: Assessments 96-3, 96-5 and 96A were completed in the first quarter of FY 1996 and are therefore not included in this SER for CY 1996.)

A structured improvement action program and follow-up are critical to the success of the assessment program. YMP requirements mandate that responsible affected organization managers respond to assessments through development and implementation of improvement actions. Assessment closure occurs once completion of improvement actions is verified by the Assessment Team Leader and approved by the AMESH for YMSCO assessments or by the CRWMS M\&O Environmental, Safety and Regional Programs Manager for internal CRWMS $\mathrm{M} \& \mathrm{O}$ assessments. 
Table 4-1. SUMMARY OF 1996 ASSESSMENT RESULTS

\begin{tabular}{|c|c|}
\hline 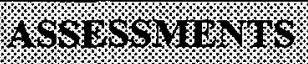 & 788 \\
\hline $96-1$ & Improved administration and tracking of ES\&H compliance surveillances. \\
\hline $96-2$ & Replaced and/or updated OSHA and EPA required signage. \\
\hline $96-4$ & Improved effectiveness of the vehicle safety awareness program. \\
\hline $96-6$ & $\begin{array}{l}\text { Established new requirements/practices for protecting open trench and } \\
\text { excavations }\end{array}$ \\
\hline $96-7$ & Verified adequacy of lockout/tagout procedures and practices. \\
\hline $96-8$ & Enhanced procedures and means for preventing Stormwater pollution. \\
\hline $96-9$ & Updated color coding system for assured equipment grounding. \\
\hline $96-10$ & Improved management of waste accumulation facilities. \\
\hline 96B & Enhanced hazardous materials inventory tracking procedures and practices. \\
\hline $96 \mathrm{C}$ & $\begin{array}{l}\text { Improvement implementation of industrial hygiene program safety and } \\
\text { training requirements. }\end{array}$ \\
\hline $96 \mathrm{D}$ & $\begin{array}{l}\text { Enhanced definition and implementation of organization ES\&H program roles } \\
\text { and responsibilities. }\end{array}$ \\
\hline $97 \mathrm{~A}$ & Enhanced implementation of radiation protection program requirements. \\
\hline 97B & Clarified roles and responsibilities for completing permit compliance actions. \\
\hline
\end{tabular}

Note: Assessment actions for 96-3, 96-5, and 96A were completed prior to January 1, 1996.

Three functions integral to the ES\&H oversight process are (1) identifying new or revised regulatory requirements as they are issued by governing agencies; (2) notifying appropriate Project personnel of these requirements and their potential impact on YMP activities; and (3) verifying that applicable requirements are properly implemented in Project ES\&H programs and activities. The ESHCD performs these functions for the AMESH by reviewing Federal Registers, DOE Orders, professional publications, and Internet sites for proposed or newly issued Federal agency rulings, DOE policies, or-other pertinent ES\&H information. Results of these regulatory reviews are posted 
electronically on a Project-wide ES\&H Notifications database and are provided to the AMESH in quarterly summary reports. During 1996, 167 notifications were provided to Project personnel on ES\&H topics that included issues and rulings relating to the CAA, CWA, RCRA, NEPA, ESA, CERCLA, and Occupational Safety programs. The ESHCD also reviewed 93 YMP plans, procedures, and special reports for ES\&H compliance.

\subsection{ENVIRONMENTAL SURVEILLANCE PROGRAM}

The environmental surveillance program constitutes a significant oversight effort by the DOE to achieve full environmental compliance through routine, unannounced "spot checks" of normal YMP activities. Environmental Programs Department (EPD) surveillances may cover any or all of the items investigated during an assessment and include, but are not limited to, the following: (1) environmental requirements specified in DOE/YMP documents (e.g., DOE Orders, YMP plans and procedures) written for or about an activity; (2) environmental permit conditions applicable to an activity; (3) applicable land access and/or ROWR conditions; and (4) Federal and State environmental regulations.

In 1996, 282 environmental surveillances were conducted by the EPD. A surveillance is closed once corrective actions for any noted discrepancies have been completed, verified by the EPD, and reviewed and approved by the AMESH. 


\subsection{ENVIRONMENTAL RADIOLOGICAL PROGRAM}

Again in 1996, the Radiological Control Division (RCD) of the Radiological/

Environmental Field Programs Department for the YMP was responsible for monitoring environmental radiological conditions in the Yucca Mountain region. The RCD supervised the overall environmental radiological monitoring program and analyzed, evaluated, and reported data generated by the program. Implementation of the program was also carried out by Division personnel, who installed and maintained field equipment, collected data recorded in the field, and performed validation procedures on the accumulated data. In addition, the RCD retained responsibility for conducting two types of surveillance for the presence of radionuclides in the environment: surveys administered prior to the commencement of a surface-disturbing activity (i.e., the pre-activity survey), and those executed periodically at site facilities and along roadways.

The 1996 monitoring program included the quantification of ambient gamma radiation, ambient radon, and radionuclides (both naturally occurring and man-made) in the Yucca Mountain vicinity. Environmental media sampled and monitored during the year were air (as a carrier of radioactive particles and gas), vegetation, biota, water, and soil. A synopsis of the monitoring regime during the year is given in Table 5-1.

The environmental radiological monitoring study area is defined as a circular grid with a radius of $84 \mathrm{~km}(52 \mathrm{mi})$ centered on the northeastern side of Exile Hill at the Yucca Mountain site. For monitoring purposes, the study area is divided into two sections, designated near-field and far-field. Near-field sites are located in the proximity of actual or expected areas of activity or disturbance that lie within $16 \mathrm{~km}$ (10 mi) of the circle's center (see Figure 3-1, p. 3-21). The portion of the grid extending beyond $16 \mathrm{~km}(10 \mathrm{mi})$ from the site is referred to as the far-field area. Since the beginning of FY 96, no radiological monitoring sites have been operated by the YMP outside of the near-field area. 
Table 5-1. Synopsis of the Environmental Radiological Field Monitoring Program in 1996. Key: CAS = continuous air sampler; EIC = electret ionization chamber; $\mathrm{CRM}=$ continuous radon monitor; $\mathrm{TLD}=$ thermoluminescent dosimeter; $\mathrm{PIC}=$ pressurized ionization chamber.

\begin{tabular}{|c|c|c|c|c|}
\hline $\begin{array}{l}\text { Sample } \\
\text { Sourcet } \\
\text { Equipment }\end{array}$ & $\begin{array}{l}\text { Number of } \\
\text { Monitoring } \\
\text { Sampling } \\
\text { Locations. }\end{array}$ & $\begin{array}{l}\text { Trequency } \\
\text { Collection }\end{array}$ & Parameter Analyzed & $\begin{array}{l}\text { Frequency } \\
\text { Anailysis }\end{array}$ \\
\hline${ }^{\text {Air/ }}$ CAS & 5 & $\begin{array}{l}\text { Weekly } \\
\text { Weekly }\end{array}$ & $\begin{array}{l}\text { Gross alpha and beta radioactivity } \\
\text { Radionuclide concentrations }\end{array}$ & $\begin{array}{l}\text { Weekly } \\
\text { Quarterly }\end{array}$ \\
\hline EIC & 18 & Monthly & Radon & Monthly \\
\hline CRM & 2 & Continuous & Radon & Weekly \\
\hline $\begin{array}{l}\text { Ambient/ } \\
\text { TLD }\end{array}$ & 40 & Quarterly & Gamma & Quarterly \\
\hline PIC & 2 & Continuous & Gamma & Weekly \\
\hline
\end{tabular}

Two methods were used to monitor ambient gamma radiation during the year. Of these, thermoluminescent dosimeters (TLD) were used most extensively (40 near-field locations). At the end of each calendar quarter, TLDs were retrieved and sent to a vendor for processing. The exposure rate for each TLD was calculated and reported by the vendor. These data were then reviewed and validated by the $\mathrm{RCD}$, in accordance with approved procedures. The overall average quarterly TLD data for all near-field and far-field stations operated since 1991 appear in Figure 5-1. Ambient gamma radiation was consistently higher at near-field than at far-field locations, a phenomenon that may be attributable to variations in geology between near-field and far-field sites. Average exposure rates did not differ significantly from quarter to quarter at near-field or far-field TLD stations.

The second method used to determine ambient gamma radiation involved pressurized ionization chambers (PIC) at two near-field locations. These instruments operate continuously, recording the dose rate integrated over intervals of fifteen seconds. The average monthly dose rates calculated for the two PIC sites since July of 1992 are shown in Figure 5-2. 


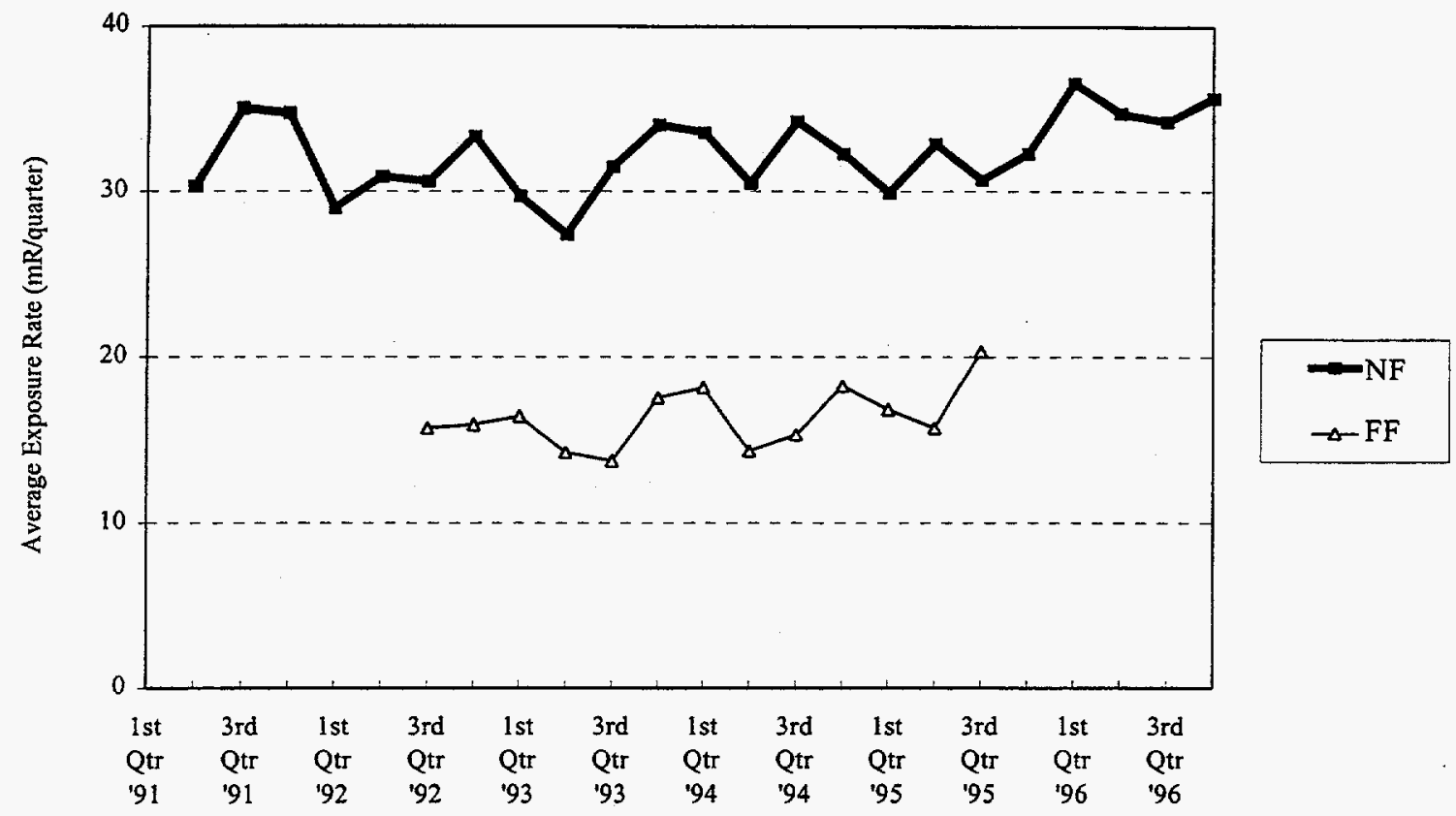

Fig. 5-1. Ambient Gamma Radiation Expressed as Average of Readings from Near-field (NF) and Far-field (FF) TLD Stations per Calendar Quarter since 1991. (FF Stations were closed as of the end of September 1995.)

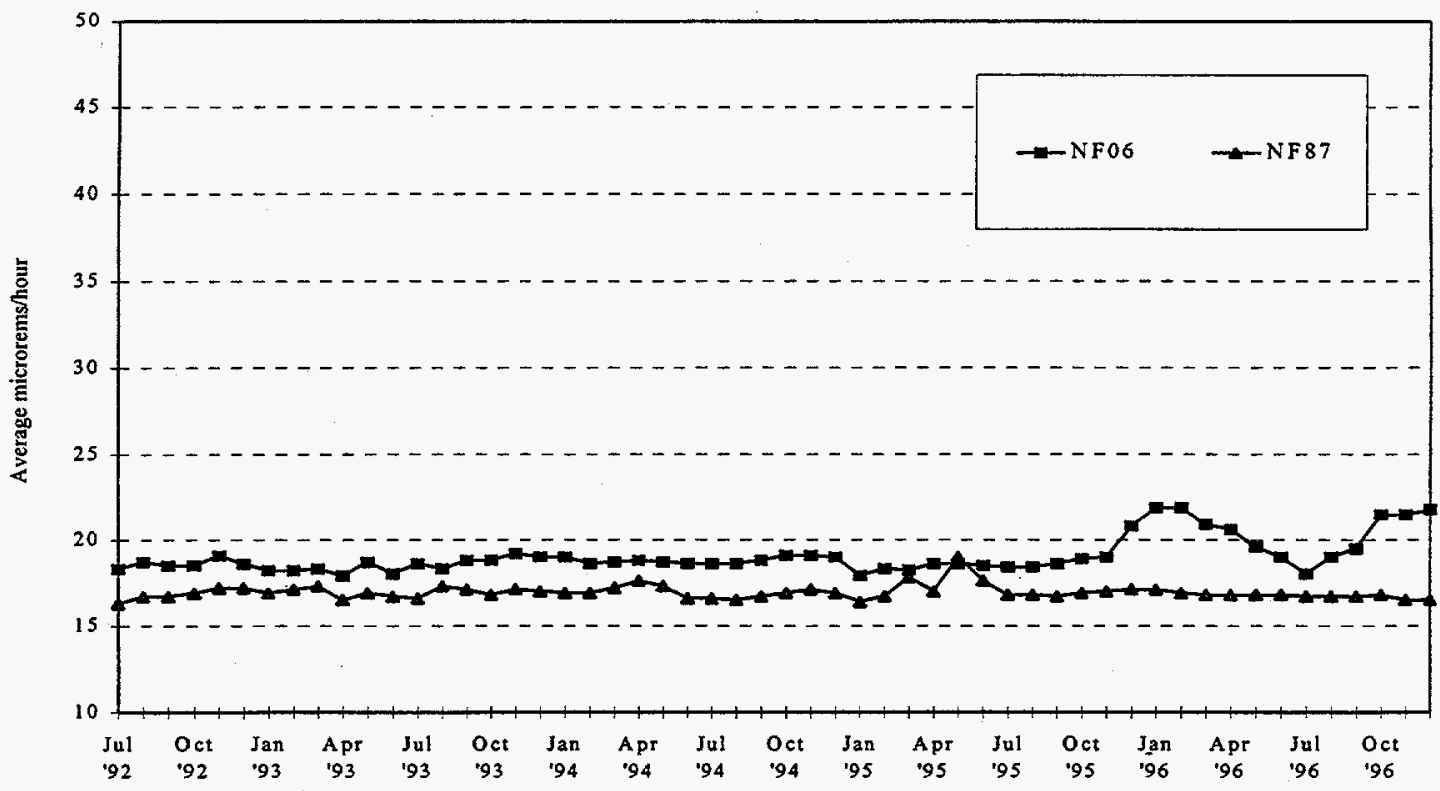

Fig. 5-2. Ambient Gamma Radiation Detected by PIC Units at the two Near-field Sites, NF06 and NF87, since mid-1992. 
Ambient radon was also monitored using two different techniques. The technique that provided data from the most sites (18 locations) was an integrated system of electret ionization chambers (EIC). The second technique used for measuring ambient radon employed continuous radon monitors (CRM). Only two CRMs were in operation during 1996. Data collected at these two sites since January of 1995 are represented in Figure 5-3. (Values for one site, NF06, were unavailable for November and December 1996 due to equipment failure).

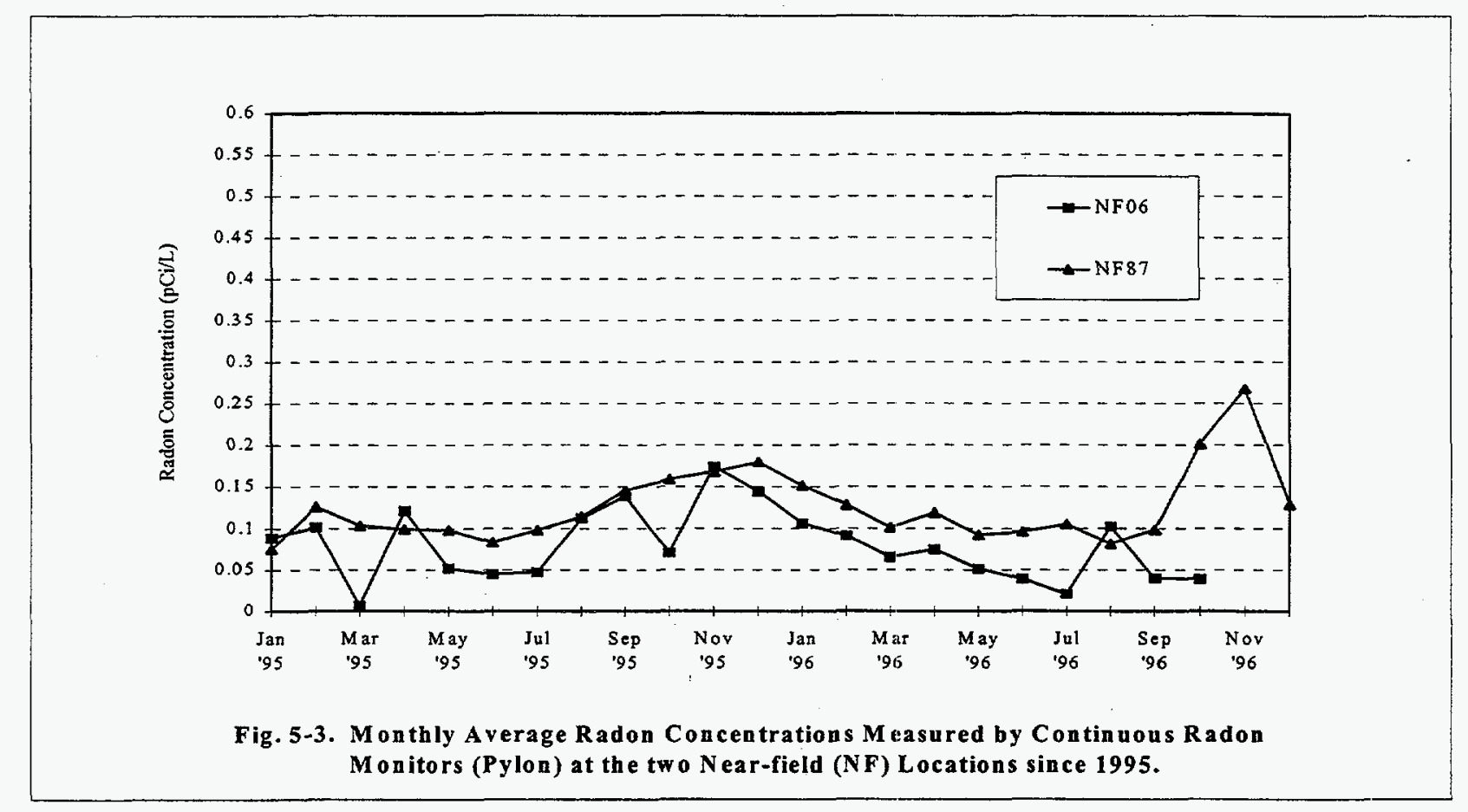

Radioactive particulates were collected by continuous air samplers (CAS) installed at five near-field locations (NF06, NF67, NF86, NF95, NF108). To measure gross radioactivity on CAS filters, an alpha/beta counting system was used. At the end of the year, filters (collected weekly and stored on site) from each CAS were composited and sent to a vendor for analysis of specific radionuclides. The results of these analyses, expressed as the annual average of gross 
alpha radioactivity and gross beta radioactivity per station at five near-field locations since 1993, are shown in Figures 5-4 and 5-5, respectively. It should be noted that a ten-fold difference exists between the units displayed along the $\mathrm{x}$-axes of Figures 5-4 (gross alpha radioactivity) and 5-5 (gross beta radioactivity).

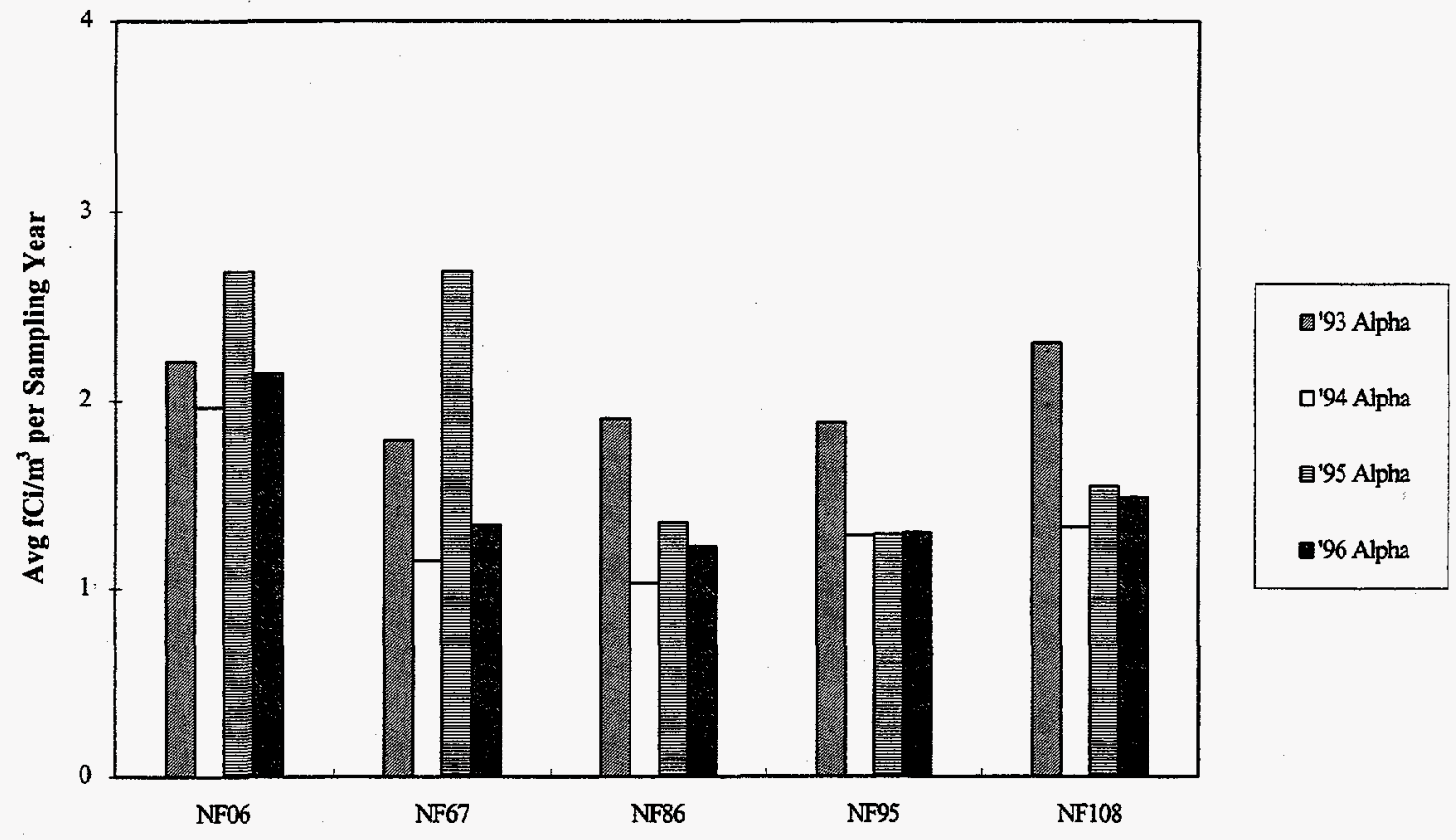

Fig. 5-4. Average Annual Gross Alpha Radioactivity at five Near-field (NF) Locations as Detected by Continuous Air Samplers since 1993. 


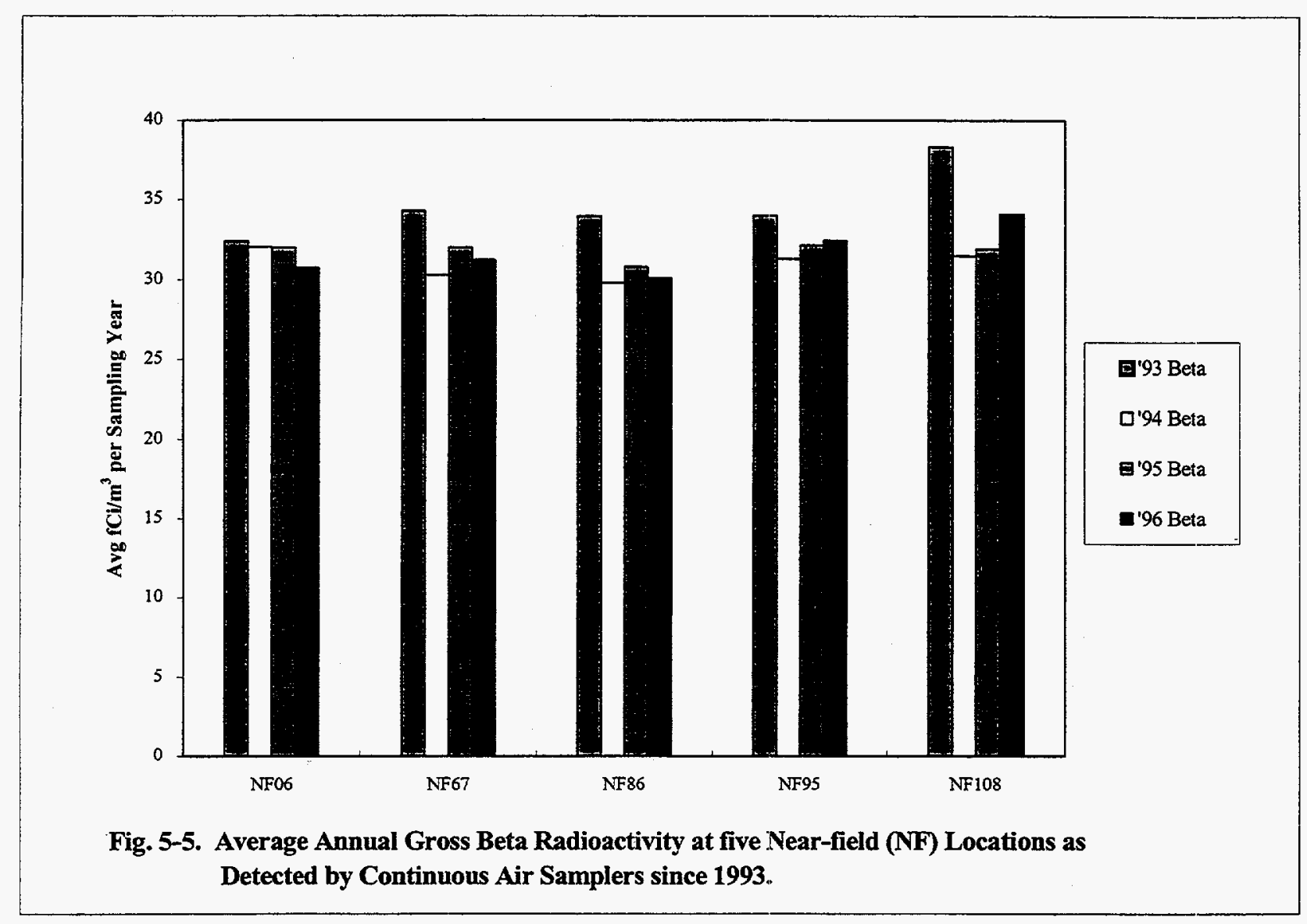




\subsection{ENVIRONMENTAL NON-RADIOLOGICAL PROGRAM}

Most of the activities occurring in this category during 1996 involved preactivity surveys (also see Sections 1.0, 3.1.6, 3.1.7.1, 3.1.14 and 6.1.1.4) and various types of monitoring. The non-radiological disciplines studied were Terrestrial Ecosystem, Cultural (i.e., Archaeological) Resources, Air Quality, Meteorology, and Water Resources. Details of the design of these investigations appear in the appropriate Environmental Field Activity Plan (EFAP) for four of the disciplines (DOE,1992b-d; 1995c) and in a study plan for Meteorology (DOE, 1993).

\subsection{MONTORING PROGRAM SUMMARY}

\subsubsection{Terrestrial Ecosystem}

This section describes the activities performed within the Terrestrial Ecosystem Program during 1996. Five areas of concern were monitored: Site Characterization Effects, Desert Tortoises, Habitat Reclamation, Monitoring and Mitigation, and Biological Sample Collection.

\subsubsection{Site Characterization Effects}

The studies in the Site Characterization Effects Program (SCEP) were designed to monitor selected components of the terrestrial ecosystem as a means of assessing the effects of site characterization activities on the ecosystem. In 1996, field studies were conducted on 19 Ecological Study Plots (ESP), each $200 \times 200 \mathrm{~m}(660 \times 660 \mathrm{ft})$ in area, to collect information on vegetation, small mammals, and climatic factors. All ESPs were located in the LarreaLycium-Grayia vegetation association (Section 2.2.4), in which most of the major disturbances during site characterization are occurring. Seven treatment ESPs and six neär-field control ESPs were established near areas of intense activity; six far-field control ESPs were located further from disturbances, near Little Skull Mountain. 


\section{Climatic Factors}

Data collected will be used to detect variations in precipitation and temperature among the ESPs. Monitoring was conducted monthly. Data recorded were maximum, minimum, and ambient air temperatures, precipitation, and soil moisture and temperature.

Precipitation in 1996 varied considerably between the ESPs. The treatment and nearfield control plots averaged 13.1 and $11.7 \mathrm{~cm}$ (5.2 and $4.6 \mathrm{in}$ ), respectively, whereas the far-field plots averaged only $8.5 \mathrm{~cm}$ ( $3.3 \mathrm{in})$ of precipitation. Average precipitation across all ESPs was $11.1 \mathrm{~cm}$ (4.4 in), substantially less than the $29.2 \mathrm{~cm}$ (11.5 in) recorded in 1994. Average maximum and minimum temperatures for all the ESPs were $35^{\circ}$ and $1^{\circ} \mathrm{C}\left(95^{\circ}\right.$ and $\left.34^{\circ} \mathrm{F}\right)$, respectively. Near-field control ESPs registered the highest, $48^{\circ} \mathrm{C}\left(118.4^{\circ} \mathrm{F}\right)$, and the lowest, $-14^{\circ} \mathrm{C}\left(6.8^{\circ} \mathrm{F}\right)$, temperatures for 1996.

\section{Vegetation}

The redesigned SCEP, implemented in 1995, had the dual objectives of monitoring far-field control ESPs located more than $10 \mathrm{~km}(6 \mathrm{mi})$ from the Yucca Mountain formation, and locating treatment ESPs as close as possible to intensive site characterization activities such as the ESF, the South Portal, and the proposed General Services Facility (GSF). Because of the large, 4-ha (10-acre) size of each ESP and the continual refinement of site characterization plans, the placement of treatment ESPs underwent modification in 1996. Most significantly, after suffering heavy damage from road construction, ESP LLG14T was discontinued and replaced by ESP LLG2T, one of the ESPs that had been part of the original SCEP.

Vegetative cover was measured on all 19 ESPs in April and May 1996. Production was measured on the four ESPs on which small mammal populations are also being monitored: LLG8C, LLG6FFC, LLG5T, and LLG11T. 
During 1996, all vegetation measurements recorded for the SCEP, from 1989 through 1994, were summarized and analyzed. Much of this analysis was published as CRWMS M\&O (1996): The Vegetation of Yucca Mountain: Description and Ecology, a report that provides a general description of Yucca Mountain plant ecology and quantifies processes that explain community structure and variability. The six-year period over which measurements were taken included periods of extreme drought as well as periods of extremely high precipitation. Cover, averaged over the total of 48 ESPs used during this period, ranged from $15 \%$ to $28 \%$, and average production ranged from 0.72 to $661 \mathrm{~kg} / \mathrm{ha}(0.65$ to $590 \mathrm{lb} / \mathrm{acre})$.

Yucca Mountain has a diverse flora. Sixty-four perennial species were measured during cover censuses, and a total of 191 species, including annuals, were identified in the Yucca Mountain vicinity during the SCEP. Diversity steadily increased with scale of measurement, from replicate transects to the entire Yucca Mountain region. Species composition on each ESP was best explained as resulting from a combination of environmental factors such as elevation, slope, soil particle size, maximum ambient temperature, and total yearly precipitation. The same factors may explain why no single species or single vegetation association dominates the Yucca Mountain flora. Seasonal precipitation patterns explained $58 \%$ of the variation in cover and $80 \%$ of the variation in production.

In addition to the description of Yucca Mountain plant ecology, plant measurements collected during the six-year SCEP were analyzed to determine if site characterization activities had an indirect impact on vegetation. Detection of impact was based on a BACI (Before-AfterControl-Impact) experimental design, and showed that site characterization activity marginally, but significantly, increased cover, production, and species richness during the SCEP. It was also determined, however, that in two vegetation associations, indirect impacts decreased plant cover on transects nearest roads. The findings of a positive BACI effect and a negative or undetectable distance effect were consistent with the array of beneficial and detrimental impacts from site characterization activities. Dust deposition increased with proximity to roads and was positively correlated $\left(R^{2}=\overrightarrow{0} .58\right)$ with traffic activity. 


\section{$\underline{\text { Small Mammals }}$}

Small mammals are useful indicators of changes in desert ecosystems because their home ranges are relatively small, their generation time is short, and they are sufficiently abundant to permit statistical comparisons. Ecologically, small mammals are important because they are common inhabitants of the desert; they consume large quantities of seeds and foliage, thereby influencing plant community dynamics; and they represent a major source of prey for carnivores. The objective of the small mammal studies was to monitor potential effects of site characterization activities on the small mammal community at Yucca Mountain by estimating changes in demographic attributes of the most abundant small mammal species. Small manamal trapping began in 1989 and will continue through FY 1997.

During 1996, trapping plots were sampled for small mammals on four consecutive nights in April, June, August, and September. Each sampling location consisted of a grid of 144 trapstations (two live-traps per station). All four plots were located in the Larrea-Lycium-Grayia vegetation community: two were treatment plots located adjacent to disturbed areas at Yucca Mountain; the other two were undisturbed control sites.

A report describing these small mammal studies was prepared and submitted to $\mathrm{DOE}$ for review during 1996. Entitled Abundance and Species Composition of Rodent Populations at Yucca Mountain, Nevada, this report (issued in March 1997) documents the abundance and distribution of desert rodents in the Mojave-Great Basin Desert transition at Yucca Mountain. Eleven species of rodents were captured during six years of live trapping on eight ESPs, and four additional rodent species were captured at other sites. Merriam's kangaroo rats (Dipodomys merriami) were found in relatively high abundance in all plots. Long-tailed pocket mice (Chaetodipus formosus) were common and widely distributed except in the sandy valley bottoms, where little pocket mice (Perognathus longimembris) were most abundant. Desert woodrats (Neotoma lepida) and canyon mice (Peromyscus crinitus) were common at high elevations during some years. 
From 1989 to 1995, small mammal populations in the vicinity of Yucca Mountain were also examined for evidence of indirect impacts due to site characterization activities. The presence of indirect impacts was evaluated by comparing the number of animals on control plots with those on treatment plots before and after November 1992, the date of grading the ESF for the North Portal. Animal abundance fluctuated over the years, but the numbers generally fluctuated in synchrony on all plots, and differences in population sizes on the control and treatment plots were generally small. Two species, little pocket mice and canyon mice, showed no impact-related changes in population size.

\section{$\underline{\text { Reptiles }}$}

Reptiles compose a significant portion of the vertebrate community in desert ecosystems. Many lizard species are habitat-specific, making them good indicators of change in habitat structure. The objectives of this study, discontinued in 1995, were to estimate species composition of the reptile community and monitor changes in abundance in relation to site characterization activities. Lizards and snakes were captured from 1991 to 1995 using a variety of sampling techniques. Reptiles were sampled throughout the Yucca Mountain area, but most sampling was conducted within the three major, low-elevation habitat types near the North Portal ESF. A total of 3,405 reptiles were captured and released, providing data on the presence, habitat preference, and habitat-specific population densities of 27 species (12 lizard, 14 snake, and 1 tortoise species). Side-blotched lizards and western whiptails were the most abundant lizards, and coachwhip and long-nosed snakes were the most abundant snakes.

Also from 1991 to 1995, studies were conducted on 25 1-ha (2.5-acre) plots to assess indirect effects of YMP activities on snakes and lizards. Over 2,500 side-blotched lizards were captured and released. This number was sufficiently large to allow a statistical analysis of the likelihood that YMP activities influenced the abundance of this species. Comparison of the numbers of individuals on control and treatment plots revealed a similar decline on both, suggesting no added effect due to site characterization activities. 


\section{Disturbance Studies}

Disturbance studies, conducted from 1992 through 1995, attempted to quantify ways in which disturbances resulting from site characterization activities might indirectly affect biotic resources. Two types of disturbance were evaluated: vehicle and construction equipment traffic, and dust deposition. Traffic volume studies were discontinued in January 1995. Dust monitoring was terminated in August 1995.

The analysis of vehicle use patterns at Yucca Mountain revealed that traffic activity at 24 treatment ESPs increased from 6.6 to 16.4 passes per day per year between 1991 and 1994. At six sites selected to represent the general trend in traffic volume across Yucca Mountain, counts increased from an average of 3.8 vehicle passes per day in 1991 to 44.4 in 1994.

The second portion of the disturbance studies, dust monitoring, used passive samplers located along vegetation sampling transects to collect dust, allowing the relationship between dust deposition and its impact on plants to be quantified. Dust deposition was positively correlated with proximity to roads and traffic volume, and the data suggested that plant cover in the two vegetation associations (Coleogyne and Larrea-Ambrosia) closest to roads was reduced.

\subsubsection{Desert Tortoise Program}

The only resident animal species at Yucca Mountain that is protected under the ESA. is the desert tortoise. The Mojave population of this species was listed by the USFWS as endangered in 1989 and reclassified as threatened in 1990. Desert tortoises are also classified as threatened by the State of Nevada. The YMSCO initiated a desert tortoise monitoring program in 1989, the goals of which were to assess and monitor the potential effects of site characterization activities on desert tortoises, develop and evaluate mitigation methods for 
minimizing those effects, and develop a better understanding of the status and ecology of the desert tortoise population at Yucca Mountain. To meet those goals, and to ensure compliance with conditions of the Biological Opinion issued in 1990 by the USFWS (following formal ESA Section 7 consultations), 308 tortoises were radiomarked and monitored between 1989 and September of 1995 at Yucca Mountain and in a nearby unimpacted, control area. Field data collection efforts for this program were completed in September 1995, and final reports are being written to document compliance with the Biological Opinion.

To determine the diet of tortoises at Yucca Mountain and maximize the benefit of habitat reclamation efforts, a study designed to identify forage species commonly eaten by desert tortoises at Yucca Mountain was conducted from 1992 to 1995 using a combination of feeding observations and scat analysis. A final report entitled Diet of Desert Tortoises at Yucca Mountain, Nevada, and Implications for Habitat Reclamation, completed in late 1995, was distributed to interested parties in 1996 (CRWMS M\&O, 1995). Findings of the diet study were summarized, and recommendations for incorporating forage species in habitat reclamation trials were presented in that document.

A report entitled The Distribution and Relative Abundance of Desert Tortoises at Yucca Mountain was completed during 1996 and submitted to the DOE for review. The objectives of this report were to summarize the findings of previous transect surveys conducted in the Yucca Mountain area during the 1980 s, and to present additional information on the distribution and abundance of tortoises collected during the period 1989 to 1995 . Surveys conducted in the 1980s indicated that the relative abundance of tortoises was low (4 to 20 animals $/ \mathrm{km}^{2}$ ). Two areas in which intensive research on radiomarked tortoises was conducted from 1989 to 1995 were identified, and the number of tortoises within these areas was tallied to determine the minimum population size. The minimum density of tortoises found in these two areas was 10 and 12 tortoises $/ \mathrm{km}^{2}$, respectively, similar to results of earlier surveys. (This report was issued in February 1997.) 
To better define the time of year during which desert tortoises at Yucca Mountain hibernate, dates on which radiomarked tortoises entered and exited hibernacula (hibernation burrows) during the winters of 1991-92 through 1994-95 were determined. Radiomarked tortoises were also monitored during the winter to determine whether they became active during their period of hibernation. Data collected indicate that, for management purposes, the period of winter inactivity for tortoises at Yucca Mountain is November 15 through February 15. A report entitled Hibernation Behavior of Desert Tortoises at Yucca Mountain, Nevada summarizes the species' hibernation patterns at Yucca Mountain. (This report was issued in February 1997).

Another report, entitled Patterns of Burrow Use by Desert Tortoises at Yucca Mountain, quantified the seasonal use of cover and the number and types of burrows used by adult tortoises. Patterns of burrow use were influenced by season, year and sex of the animals. As expected, the annual pattern of burrow use was closely related to temperature. Tortoises were located in burrows more than in other types of cover during the hottest and coldest months, and were most often found in above-ground pallets and away from cover during months with more moderate temperatures. On average, tortoises at Yucca Mountain used approximately 12 burrows per year. (This report was issued in April 1997.)

One factor thought to contribute to desert tortoise population declines is increased predation on hatchling tortoises by common ravens (Corvus corax). A term and condition of the Incidental Take Provision of the Biological Opinion (McNatt, 1990), issued by the USFWS to the DOE, was that the abundance of ravens in the vicinity of Yucca Mountain be monitored. A report completed in 1996 (and issued in August 1997) entitled The Effects of Site Characterization Activities on the Abundance of Ravens (Corvus corax) in the Yucca Mountain Area summarizes the final results of raven surveys conducted from 1991 to 1995 . While raven numbers increased on both the Yucca Mountain and control survey routes, the magnitude of differences between the two routes (Yucca Mountain versus control) did not change, suggesting that the increases in bird numbers were not related to man-induced disturbances at Yucca Mountain. 
The YMP is required to relocate desert tortoises out of harm's way if site characterization activities cannot be modified or moved to areas in which neither tortoises nor burrows have been found. Relocations of desert tortoises from 1991 through 1995 were documented, and tortoise survival, movement patterns, and indications of exposure to disease are being used to evaluate the success of relocation efforts and the impacts that relocation may have on the animals.

Home range size, annual movement patterns, and long-distance movements of desert tortoises at Yucca Mountain were studied to improve impact mitigation techniques and to better understand desert tortoise ecology. Such information can be used to improve methods for protecting tortoises at Yucca Mountain from construction activities.

Desert tortoises at Yucca Mountain were studied to evaluate the effects of site characterization activities on the prevalence of upper respiratory tract disease (URTD) in the tortoise population. A control group of tortoises was compared to two treatment groups that were characterized by the intensity and duration of human activities on or near their home ranges. Blood samples, collected from radiomarked tortoises on four occasions from September 1993 through September 1995, were tested for antibodies specific to Mycoplasma agassizii, a causative agent of URTD. In addition, any clinical signs of the disease were noted each time tortoises were handled. The results of these studies are being compiled and evaluated.

Potential direct and indirect impacts of disturbances on desert tortoises at Yucca Mountain were monitored from 1992 to 1995 . Three types of direct impacts were monitored: habitat loss, mortalities resulting from site characterization activities, and relocation of tortoises and tortoise nests from areas to be disturbed. Indirect impacts were evaluated using eight response variables measured in three groups of radiomarked tortoises differentiated by the level of impact to which they were exposed in their home range: (1) a high-impact treatment area (i.e., near large-scale, long-term disturbances), (2) an area-wide treatment area (throughout the Yucca 
Mountain area in which activities would occur), and (3) a control area (in which no Yucca Mountain activities would occur). Data from these impact analysis studies are presently being compiled.

\subsubsection{Habitat Reclamation Program}

The objective of the Habitat Reclamation Program is to restore sites disturbed by YMP activities to an ecological state similar in form and productivity to their pre-disturbance condition. The program consists of reclamation inventories, reclamation implementation (interim and final reclamation activities), reclamation monitoring (interim, final, and animal use), reclamation trials, topsoil stockpile studies, and disturbed habitat studies.

\section{Reclamation Inventories}

A Reclamation Inventory is performed before the initiation of an activity at a site from which topsoil is to be salvaged and stabilized during storage. The Reclamation Stipulation Report resulting from the inventory includes recommendations for salvaging, storing, and managing the topsoil to prevent wind and water erosion, and for maintaining soil viability. One reclamation inventory was conducted in 1996, occurring at the South Portal pad. Vegetative cover, soil depth, soil texture, and soil erodability were recorded for the Reclamation Stipulation Report. Soil samples were collected at the site and sent to a commercial soil laboratory for analysis of physical and chemical properties. By the end of the year, most South Portal pad construction activities had been completed.

\section{Reclamation Implementation}

Interim reclamation refers to efforts that may include seeding, mulching, or chemical stabilization of a disturbed area before the completion of all activities at the site. The objectives 
of interim reclamation are to prevent erosion and maintain a viable soil until activities are completed and the site is released by the YMSCO for final reclamation. Included in final reclamation are decommissioning, recontouring, and revegetation of the site.

In 1996, five topsoil stockpiles, established as a result of site characterization activities, were restabilized by seeding and mulching. Restabilization was necessary because initial attempts to vegetate the piles were unsuccessful.

Twenty-three sites were released for final reclamation in 1996: 20 were Midway Valley pits and three were Stagecoach Road trenches. Only 17 of the 20 Midway Valley pits were reclaimed, however; access to the other three pits was denied to avoid the possibility of breaking an above-ground plastic water line. Following site preparation, the 20 accessible sites (17 at Midway Valley, three at Stagecoach Road) were seeded in November with a mixture of native plant species, then mulched with straw and stabilized with a crimper or chemical tackifier. Reclamation success will be monitored at these sites.

\section{Reclamation Monitoring}

In 1996, both interim reclamation sites and final reclamation sites were monitored to assess soil stability and the success of revegetation efforts. Of the interim sites, 82 topsoil stockpiles were checked for soil erosion. Five long-term (i.e., more than six months old) stockpiles were reseeded in December. Two stockpiles required additional applications of Soil Master WR ${ }^{\mathrm{TM}}$. Twenty-three stockpiles were monitored for the last time, as all 23 sites were released for final reclamation (see previous section). The soil from these stockpiles was used in reclamation efforts.

Final reclamation monitoring was conducted at 54 sites in the spring of 1996 to determine whether additional reclamation measures were necessary. Nineteen of these sites were monitored qualitatively (visual observations and estimates), while quantitative data (plant density and 
vegetative cover) were collected from the remaining 35 sites. Included in the latter group were 29 GSF test pits, Trench A'2, Well JF-3, NRT-1 trench, UZN-85 drill pad, Large Rocks collection site and the sewerline. Plant cover was recorded at Trench A'2 and Well JF-3 while, at the remaining sites, plant density was measured.

A new study, implemented in 1995, continued in 1996 at Reclamation Trial Site 1 and the NRT-1 Final Reclamation Site. The objective of the study was to document the level of use of reclaimed areas by wildlife, using small mammals as indicator species. Numbers of individuals and species composition of the small mammal community using these reclaimed areas is to be compared with the same parameters on adjacent undisturbed (control) areas. Animals were trapped in May and October at these sites.

\section{$\underline{\text { Reclamation Trials }}$}

Data collected from reclamation feasibility studies conducted during the period 1991 to 1995 have been analyzed. In summary, results of these studies have shown that revegetation by direct seeding of native, adapted species can be successful in the Mojave Desert during years of above-average precipitation. Conditions were conducive for plant establishment during 1992-93 and again in 1995. The direct seeding studies were conducted and monitored during these wret periods, possibly a factor in the success of the studies. The continuing goal of the reclamation program at Yucca Mountain will be to repeat these successes, using alternate strategies, in years with average or below-average rainfall. Continued study of techniques such as irrigation and transplanting will improve the ability of reclamation scientists to find successful revegetation methods for use during these dry periods. Based on the results of these feasibility studies, recommendations were made for implementing reclamation measures at Yucca Mountain and for evaluating additional reclamation techniques. 
Three new studies were implemented during late fall and winter 1996. The objective of one study, at the ESF Topsoil Stockpile, was to determine if the period of the year during which most reclamation is accomplished at Yucca Mountain (October to December) could be extended into late winter and early spring by irrigation. Eight 10- x 10-m (33- x 33- ft) plots were ripped, seeded with 15 native shrub, forb, and grass species, and mulched with wheat straw during December 1996. The treatments will be applied to eight more plots during February, March, and May 1997. One-half of the plots will be irrigated for approximately one month following treatment application. The other plots will be treated as controls and will not be irrigated. Seedling density sampling of seeded species and annuals will be conducted during the spring and summer of 1997 to determine seedling emergence. Sampling to determine survival will occur in the fall after the first growing season and at the end of the second and third growing seasons.

A second study was designed to determine if seeds of native plant species will germinate with irrigation 16 to 18 months after they are sown. To meet this objective, a site at the sewer line corridor, seeded in fall 1995, will be divided into plots and irrigated for approximately one month. Density data will then be collected. Data from irrigated and non-irrigated plots will be compared with each other, then compared to baseline plant density data collected at the study site during the fall of 1996. If plant densities from irrigated plots are statistically greater than baseline densities, consideration should be given to utilizing irrigation to remediate disturbed sites with limited plant densities and viable seedbanks. Further, if plant densities from nonirrigated plots are greater than baseline densities, it is possible that nothing should be done with these disturbed sites, allowing natural precipitation to initiate germination and subsequently increase plant densities.

The objective of the third study was to determine effects of dormancy-breaking treatments and irrigation on the emergence of creosotebush (L. tridentata) and Anderson desert thom ( $L$. andersonii). The design of this study is to maximize the germinability of creosotebush and Anderson desert thorn seeds with dormancy-breaking treatments, then provide optimal soil water and temperature conditions for germination and seedling emergence. These conditions will 
be provided by irrigating only after soil temperatures are above $23^{\circ}$ to $26^{\circ} \mathrm{C}\left(73^{\circ}\right.$ to $\left.79^{\circ} \mathrm{F}\right)$ in late summer.

A site on the ESF Topsoil Stockpile was prepared for this study in December 1996, and plots will be identified in January 1997. Creosotebush seeds will be treated with water leaching, while seeds of Anderson desert thorn will be treated with stratification (moist/cold treatment). The plots will be seeded and mulched with wheat straw in January and August 1997. Two sowing dates are necessary because a question exists as to whether the effects of dormancybreaking in late fall or winter will still be manifest in August when germination is expected to occur. Therefore, seeds of both species will be treated for dormancy in December and January prior to the January seeding date, and again in July and August prior to the August seeding date. Seedling density sampling of seeded species and annuals will be conducted to determine seedling emergence, plant establishment, and plant survival. Seedling density will be sampled in September 1997. Sampling to determine survival will occur during the spring of 1998.

To determine the effects of irrigation and dormancy-breaking treatments on the timing of germination of creosotebush and Anderson desert thorn seeds, nylon-mesh seedbags containing seeds of both species will be buried beneath the soil surface and will be retrieved just prior to the start of irrigation, and two, four, six, and eight weeks after irrigation is initiated. Following retrieval, seeds will be removed from the bags and analyzed to determine numbers of germinated and viable seeds.

\section{Topsoil Stockpile Studies}

Studies were undertaken at two sites at Yucca Mountain in 1993 to determine the effects of stockpiling on topsoil. Results of studies elsewhere indicate that prolonged stockpiling disrupts nutrient cycles, reduces organic matter, increases bulk density, and disturbs soil microbial populations. 
At the first site, a stockpile was created from topsoil removed during the excavation of Borrow Pit \#1. After stockpile completion, four revegetation treatments were applied, each consisting of a seed mix having a different proportion of shallow-rooted, deep-rooted, and legume species. These mixes were selected in an attempt to create stands of vegetation having different root profiles. Soil sampling began in May 1993. Samples were collected from five depths in each revegetation treatment plot, with samples also being collected in adjacent undisturbed topsoil to assess baseline conditions. Sampling occurred approximately every month until December 1993 to determine short-term effects of stockpiling. After December 1993, samples were collected every six months to determine long-term effects. For each sampling period, stockpile status was assessed by measuring active and total bacterial biomass, active and total fungal biomass, vesicular-arbuscular mycorrhizae (VAM) spores, soil physical properties, and soil chemical properties.

At the second site, a stockpile was formed from topsoil removed during the NRG-6 drill pad construction. After stockpile completion, one half of the NRG-6 pile was seeded with a grass/shrub mixture and the other half with shrubs only. Soil sampling began in May 1993 and continued approximately every six months until May 1995.

During 1996, no soil data were collected at the Borrow Pit \#1 or NRG-6 stockpiles. However, soil data collected at the Borrow Pit \#1 stockpile prior to 1996 were analyzed to determine the effectiveness of the revegetation treatments and the short- and long-term effects of topsoil stockpiling. Analyses indicated that no revegetation treatment resulted in consistently higher levels of soil attributes. This response was considered due to the lack of proportional differences between the species seeded on the stockpile. Bacteria and fungi were not affected by depth of the stockpile, though during the first year of the study, bacterial and fungal components in the stockpiled soil were significantly different than those in the undisturbed soil. During the second year, stockpiled topsoil performed much as did the undisturbed soil. 


\subsubsection{Monitoring and Mitigation Program}

Important species are those listed by the USFWS or the State of Nevada as threatened, endangered, or of commercial and recreational value. One of the primary goals of the terrestrial ecosystem monitoring and mitigation program is to preserve important plant and animal species and their associated habitats that may be impacted by site characterization activities. A mitigation tool used by the YMP is the field survey to detect the presence of important plant and animal species prior to initiation of land-disturbing activities. As a result of these preactivity surveys, additional mitigation measures such as resurveys or continuous monitoring may be: recommended. Subsequently, upon completion of a land-disturbing activity and before a site is declared ready for reclamation, a postactivity survey is usually conducted.

Two preactivity survey requests resulted in surveys of two separate sites during the year. Approximately 46.3 ha (114 acres) were surveyed, all within the range of the desert tortoise. One tortoise was found. Burrows or other signs indicating the presence of tortoises were found during both surveys.

As a result of these surveys, site-specific recommendations were made for purposes of minimizing the possibility of harming tortoises and reducing impacts on other biological resources. These included one recommendation to conduct resurveys for tortoises immediately prior to construction, another that a trained biologist be present at the time of construction, and a third to move an ESP to avoid its destruction by the proposed activity.

Because the removal of transmitters from all tortoises during the previous year made it impossible to monitor tortoises by radiotelemetry in construction areas, monitoring efforts to minimize harm to tortoises were modified. All sites at which surface-disturbing activities occurred during the tortoise activity period (March 1 through November 15) were resurveyed to search for tortoises every day on which the activity occurred. Activities that occurred outside of the tortoise activity period were resurveyed once during the period of inactivity. Ten resurveys 
were conducted for two activities at two sites. Approximately 4.1 ha (10 acres) were resurveyed. No tortoises were found. Of nine burrows located within the proposed activity areas, six had collapsed naturally and three were collapsed by biologists after being checked for tortoises and eggs. One unoccupied burrow located within $15 \mathrm{~m}(49 \mathrm{ft})$ of an activity was blocked to prevent entry by a tortoise should the activity extend beyond its expected boundaries.

Another category of survey exists, conducted for activities not expected to significantly disturb additional land surfaces (e.g., backfilling of pits or installation of seismometers). The approval process for such surveys, involving fewer review and administrative steps, may be expedited. Three requests for such surveys resulted in 27 surveys at 26 sites. Twenty-four of the 27 surveys were real-time surveys, which entailed accompanying work crews as they performed the requested action (backfilling pits). The remaining three surveys were not within the range of the desert tortoise and, therefore, did not require the presence of a biologist during the activity. Approximately 7.0 ha (17.3 acres) were surveyed in this manner within the range of the desert tortoise, while 2.2 ha (5.4 acres) outside of tortoise range were surveyed. No tortoises or other important species were found. Burrows or other signs indicating the presence of tortoises were found during one of these surveys.

Two postactivity surveys were conducted in 1996: one for a trench excavated in 1983, the other for four seismometer stations installed in 1996. The trench was excavated prior to the 1989 emergency listing of the desert tortoise; therefore, no preactivity survey had been conducted. The seismometer stations disturbed only a negligible amount of land.

The amount of land disturbed by activities has routinely been recorded in the past because, until May 1996, the State of Nevada limited the YMP to disturbing no more than 188.25 ha (465 acres) during site characterization (Section 3.1.3.1). Despite removal of this restriction by the State in May, the YMSCO continued to track and record acreage disturbed. Two methods of estimating the area disturbed in 1996 were used, with the data ultimately entered into a GIS. Approximately 4.9 ha (12 acres) were disturbed by YMP activities in 1996, bringing the total 
since June 21,1991 , to approximately 114.9 ha (284 acres). This number is less than that reported in previous annual reports because more accurate techniques were used to remeasure previously surveyed disturbances.

\subsubsection{Biological Sample Collection}

The objectives of this program were to collect plant and animal specimens for the determination of radionuclide concentrations in their tissues, and to monitor populations of the animal species being collected for this purpose. No samples were collected in 1996.

As part of this program, the relative abundance of lagomorphs and predators was monitored from 1990 through 1995. During 1992, 1993, and 1994, lagomorphs were numerous, but during 1990, 1991, and 1995, abundance was low and harvest would have been difficult: and expensive. The number of jackrabbits seen per $\mathrm{km}$ of road fluctuated from a low of 0.01 in 1991 to a high of 1.5 in 1994, before declining to fewer than 0.4 in 1995 . Jackrabbit populations on the east and west sides of Yucca Mountain generally fluctuated in synchrony. Although populations fluctuated greatly, correlations between precipitation and abundance of animals were high. It was concluded that historic precipitation records could be used to predict periods of high animal abundance and, therefore, the most efficient times to harvest lagomorphs.

\subsubsection{Archaeological Resources}

Areas of proposed land disturbance were examined in advance to identify and evaluate historical properties and to ensure avoidance or mitigation of potential adverse effects to those properties by YMP-related activities. A total of 11 archaeological preactivity surveys of areas proposed for Project activities were made during the past year (Section 3.1.7.1). Surveys of YMP areas resulted in the identification and recording of three new historical properties. 
The DOE archaeological support contractor has implemented an archaeological site monitoring program, designed to periodically assess the condition of known historical properties in the main Project area around Yucca Mountain. During 1996, a total of 45 historical properties were revisited for purposes of site monitoring. The results of these visits indicated that historical properties were largely in the same condition as when discovered or last examined.

\subsubsection{Air Quality}

In accordance with the requirements of the air quality permit issued by the State of Nevada in 1991 (Section 3.1.3.1), the YMP monitors and reports particulate matter equal to, or less than, 10 micrometers in nominal aerodynamic diameter $\left(\mathrm{PM}_{10}\right)$. Sampling is conducted every sixth day for 24 consecutive hours at four locations: Site 1 (NTS-60), Site 5 (Fortymile Wash), Site 6(WT-6), and Site 9 (Gate 510) (Figure 6-1). To assess the precision of measured concentrations, in compliance with regulatory quality assurance requirements, two collocated $\mathrm{PM}_{10}$ samplers are operational at Site 1 .

As of the end of 1996, 80 months of particulate matter data had been processed to meet the requirements of the air quality permit. Figure 6-2 reveals an annual trend of higher concentrations of $\mathrm{PM}_{10}$ during the summer months and the occurrence of individual episodes of higher values throughout the year. During 1996, the highest reported value for a 24-hour period was $60 \mu \mathrm{g} / \mathrm{m}^{3}$, well below the 24-hour ambient air quality standard of $150 \mu \mathrm{g} / \mathrm{m}^{3}$. Most values, in fact, did not exceed $15 \mu \mathrm{g} / \mathrm{m}^{3}$. The highest annual average for any of the four sites, derived by averaging all 24-hour values for the year from each site separately, was $10 \mu \mathrm{g} / \mathrm{m}^{3}$, one-fifth the annual ambient air quality standard of $50 \mu \mathrm{g} / \mathrm{m}^{3}$.

\subsubsection{Meteorology}

For the fourth successive year, nine sites were operated in the meteorological network (Figure 6-1). The first five sites (NTS-60, Yucca Mountain, Coyote Wash, Alice Hill and 


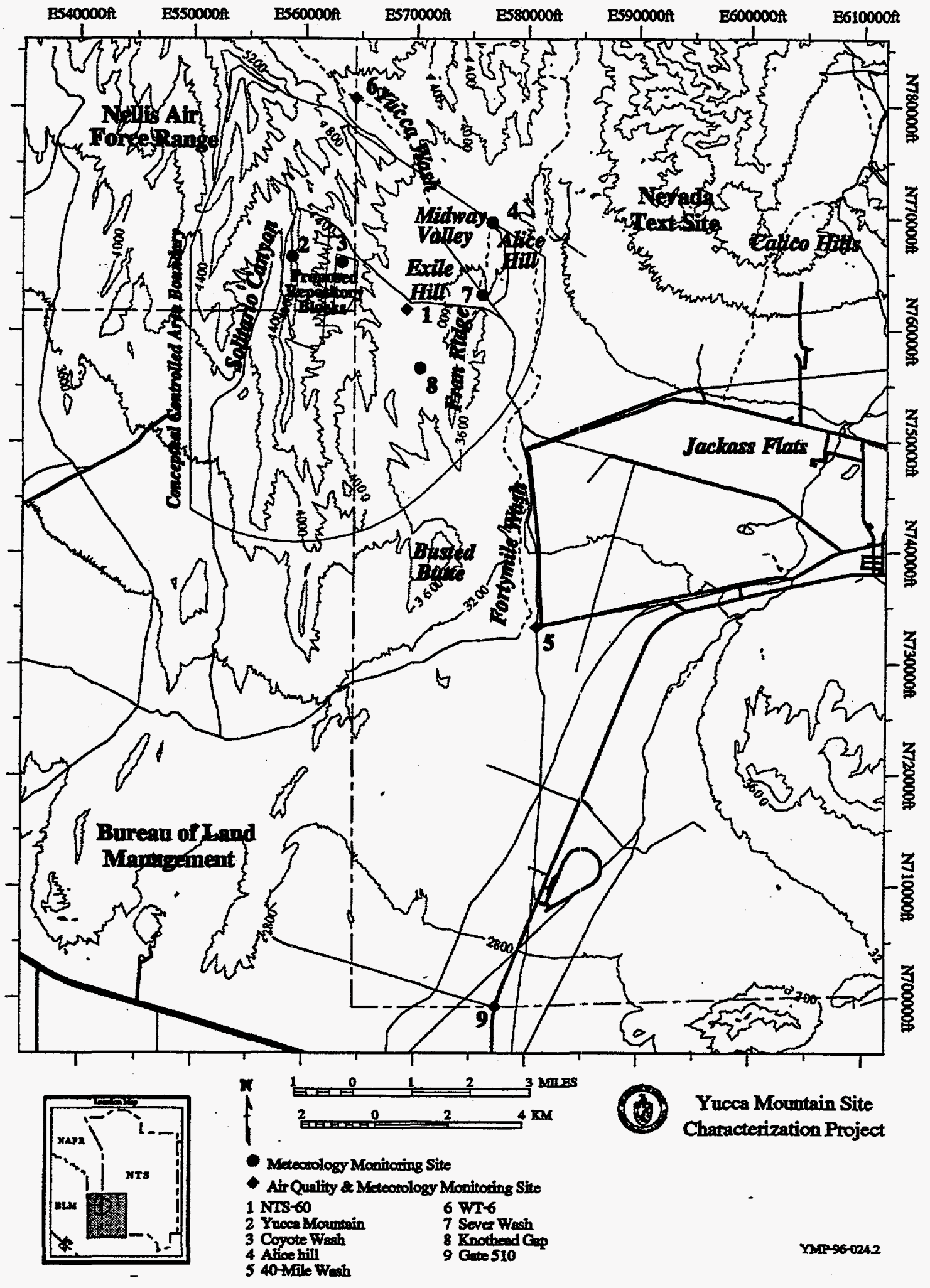

Figure 6-1. Air Quality and Meteorology Monitoring Sites 


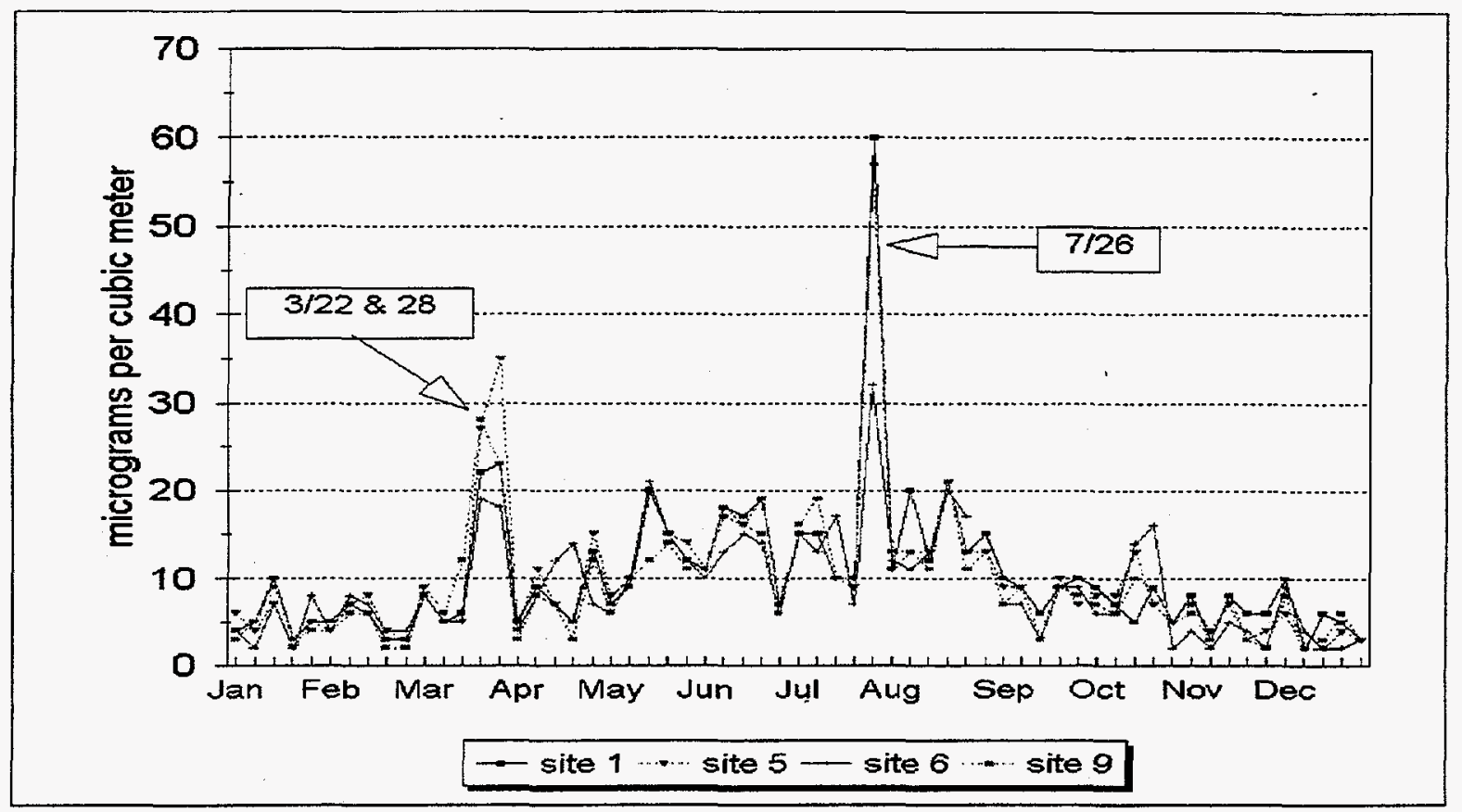

Figure 6-2. Inhalable Particulate Matter $\left(\mathbf{P M}_{10}\right)$ Measured in 1996 at the four Yucca Mountain Air Quality Monitoring Sites: 1 (NTS-60), 5 (Fortymile Wash), 6 (WT-6), and 9 (Gate 510).

Fortymile Wash) have operated since December 1985. In addition to increasing the number of sites, the measurement program has expanded in keeping with changing regulatory guidance on supplying meteorological data as input to atmospheric dispersion models. The equipment and operational methods used comply with U.S. EPA Prevention of Significant Deterioration (PSD) monitoring guidance.

Wind measurements at all nine sites are recorded $10 \mathrm{~m}$ (33 ft) above ground level (AGL); Site 1 (NTS-60) also takes wind measurements at $60 \mathrm{~m}$ (197 ft) AGL. Since September 1993, temperature and atmospheric humidity measurements have been recorded at $2 \mathrm{~m}(6.6 \mathrm{ft})$ AGL. (Prior to that date, these measurements were taken at $10 \mathrm{~m} \mathrm{AGL}$.) Various indicators of atmospheric stability are reported from all sites. For example, the hourly standard deviation of wind direction (known as sigma-theta and sigma-A) has been measured since the beginning of the program. Barometric pressure and precipitation measurements provide additional meteorological information needed in climate and airflow studies. 
The primary use of the data from all sites is to characterize local meteorological conditions and support radiological transport calculations. Depending upon the location of these sites, the acquired data will serve additional purposes. For example, data from Site 1 can be used to assess possible impacts associated with site characterization and/or repository operations. Data from Sites 5 (Fortymile Wash) and 9 (Gate 510) will indicate airflow pathways between the Midway Valley site characterization area and the Amargosa Valley area to the south. Site 7 (Sever Wash) is important for monitoring both up-valley daytime winds and nighttime drainage flows through Midway Valley. Site 8 (Knothead Gap) will monitor winds in the south end of Midway Valley.

Results from the meteorological monitoring prograrn are reported in annual summary reports. Average wind speeds during 1996 continued to be high enough to be conducive to good atmospheric dispersion, since higher wind speed provides greater dilution of airborne emissions. The lowest annual average wind speed at any site was $2.7 \mathrm{~m}$ per second $(\mathrm{m} / \mathrm{s})$ or $6.1 \mathrm{mi}$ per hour (mph) at the protected canyon location at Site 3 (Coyote Wash). The highest annual average speed was $4.8 \mathrm{~m} / \mathrm{s}(10.7 \mathrm{mph})$ at the exposed hilltop location at Site 4 (Alice Hill), in the northeast portion of Midway Valley. The highest 3-second wind speed gust, $37.2 \mathrm{~m} / \mathrm{s}$ ( $83.2 \mathrm{mph}$ ) was also recorded at Site 4.

Preliminary analyses indicate that precipitation totals for 1996 were very close to the average for the local area. The total at Site 1, the tall tower site near the North Portal of the ESF, was $12.88 \mathrm{~cm}(5.07 \mathrm{in})$, virtually identical to the $12.90 \mathrm{~cm}$ (5.08 in) 11-year average for this site. The relationships of precipitation totals between the individual sites was similar to previous years. Totals ranged from a dry $7.06 \mathrm{~cm}$ (2.78 in) at Site 9 near the Amargosa Valley community on State Highway 95 to $14.58 \mathrm{~cm}$ (5.74 in) at Site 6 (WT-6) in upper Yucca Wash, immediately north of the Yucca Mountain ridge. 


\subsubsection{Water Resources}

The Yucca Mountain Water Resources Program consists of monitoring water quantity for purposes of documenting any potential effects of site characterization activities on regional water resources and satisfying water-related regulatory and program requirements. The study area for the Water Resources Program encompasses the majority of the site characterization study area and additional sensitive areas to the south of Yucca Mountain (Figure 6-3). Included are the Ash Meadows spring-discharge area and Devils Hole, which together harbor a number of endemic plant and animal species.

Because surface water is present in the Yucca Mountain region only during infrequent brief storms, the monitoring of water quantity is restricted to inventorying groundwater resources. Assessing the status of these resources essentially involves three types of monitoring. The first is that of measuring levels of groundwater in 35 wells over time (Figure 6-4). These data are being used to characterize historical and current water resources in the region, and to indicate changes in the quantity of groundwater stored or transmitted within aquifers through time. The same objective is served by the second type of monitoring, i.e., measuring groundwater discharge (or in-flow) into five springs and one well. In particular, these discharge measurements provide data that indicate the status of certain critical water supplies in the environmentally sensitive Ash Meadows and Death Valley areas. The third type of monitoring provides an estimate of regional groundwater withdrawals or water use, both current and historical, by means of an ongoing review of information collected by public or private entities.

Routine data collection commenced in February 1992. Initially, measurements were made monthly at wells and quarterly at springs. The frequency of data collections has been revised, however, as evaluations of water-level and spring-discharge data are completed. In 1996, wells and springs were measured quarterly, monthly, or hourly, as testing demands dictated. 


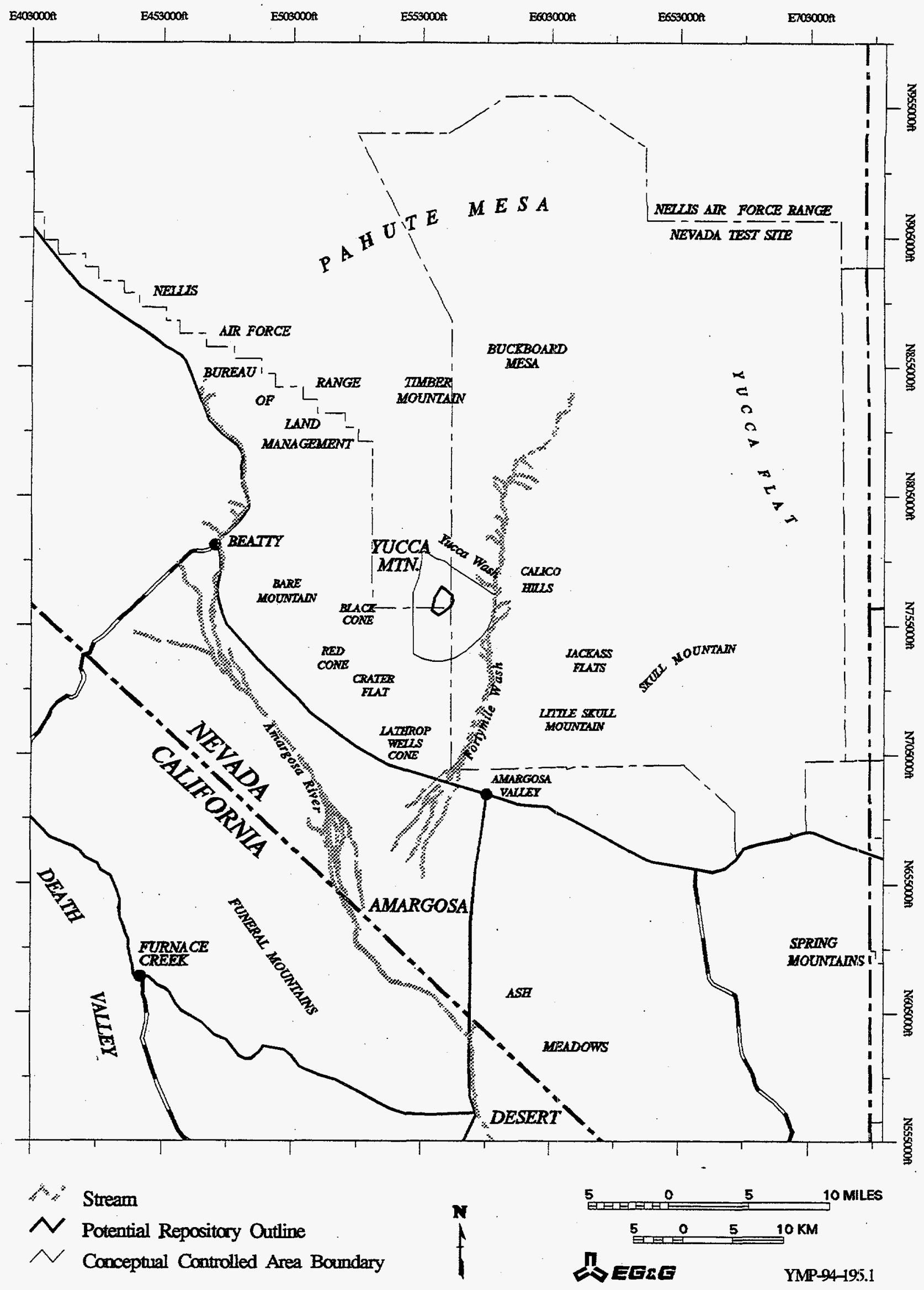

Figure 6-3. Study Area for the Yucca Mountain Project Water Resources Program 


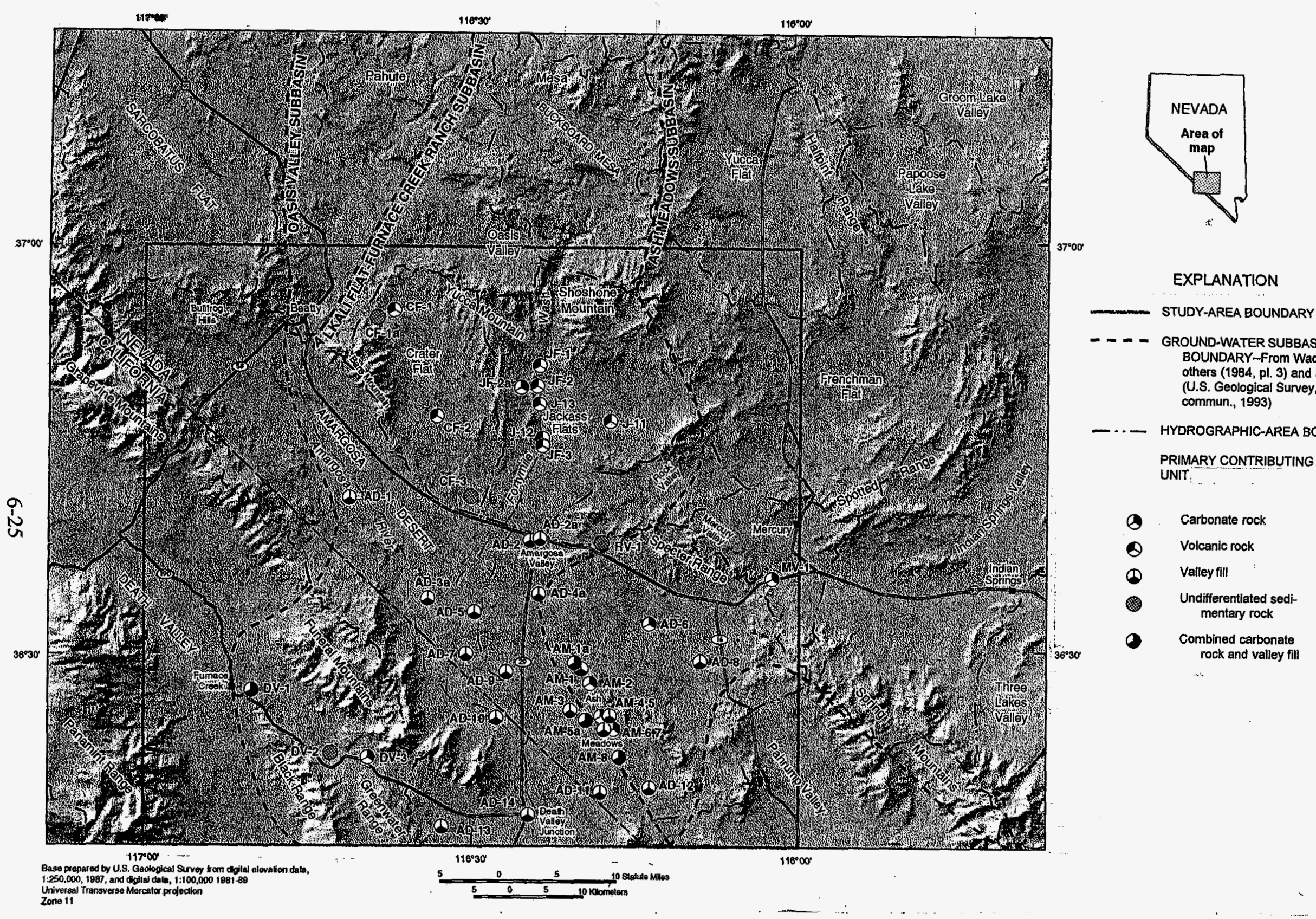

Figure 6-4. Groundwater Level and Discharge Monitoring Sites in the Yucca Mountain Region, Southern Nevada, and Eastern California 
Monitoring well JF-3, routinely monitored since May 1992, is located and designed to detect impacts that might be caused by pumping at the well complex consisting of wells J-12 and J-13. Provisional data provided by the USGS indicate that fluctuations in water levels in these three wells (JF-3, J-12 and J-13) during 1996 ranged from 0.22 to $0.33 \mathrm{~m}(0.72$ to $1.07 \mathrm{ft})$ (USGS, 1996a,b,c,d). The ranges in water levels (expressed as meters and feet below land surface) and fluctuations in each well were as follows:

JF-3: 216.36 to $216.69 \mathrm{~m}(709.85$ to $710.92 \mathrm{ft})$; difference $(\Delta)$ of $0.33 \mathrm{~m}(1.07 \mathrm{ft})$.

J-12: 225.52 to $225.83 \mathrm{~m}(739.89$ to $740.91 \mathrm{ft}) ; \Delta$ of $0.31 \mathrm{~m}(1.02 \mathrm{ft})$.

J-13: 282.86 to $283.08 \mathrm{~m}$ (928.01 to $928.73 \mathrm{ft}) ; \Delta$ of $0.22 \mathrm{~m}(0.72 \mathrm{ft})$.

In accordance with stipulations of the water monitoring program developed by the DOE and its contractors in 1991 and approved by the National Park Service (NPS), reports listing; groundwater-level and springflow data are prepared and submitted by the DOE to the NPS and the State of Nevada each quarter of the year.

A report prepared by the USGS, entitled Selected Ground-Water Data for Yucca Mountain Region, Southern Nevada and Eastern California, through December 1994," was issued in 1996 (USGS, 1996e). Data and text are presented that describe groundwater levels, groundwater discharges, and groundwater withdrawals in Jackass Flats, Mercury Valley, and the Amargosa Desert.

\subsection{ENVIRONMENTAL OCCURRENCES}

Although petroleum products are not considered hazardous by the State of Nevada, a report is required by the State for any release onto a land surface of a petroleum product that exceeds 95 liters ( $25 \mathrm{gal}$ ) or that contaminates more than $2.3 \mathrm{~m}^{3}$ or $3 \mathrm{yd}^{3}$ of soil at a concentration greater than $100 \mu \mathrm{g} / \mathrm{kg}$. In 1996, three petroleum releases exceeded the State reporting threshold: 
two consisted of diesel fuel, the third was hydraulic oil. Both spills of diesel fuel were the result of equipment failure. In one instance, a fuel delivery sensor failed; in the second, the fuel tank on a truck was pierced by a rock. The hydraulic fluid release occurred when a hose on an "Alpine Miner" mining machine ruptured.

Remedial action, performed at each of the release locations, entailed excavating the site, then analyzing soil samples from the excavation using EPA Analytical Method 8015 (modified for diesel/gasoline/oil) to determine Total Petroleum Hydrocarbon (TPH) concentrations. In such cases, the decision as to whether additional soil excavation is necessary is based on the presence of $100 \mu \mathrm{g}$ of TPH per kg of soil, established by the State of Nevada as the threshold for further action.

In 1996, three shipments of excavated hydrocarbon-contaminated soil, amounting to 65 tons, were sent to a State-permitted treatment and recycling facility for bioremediation and ultimate use as landfill cover. Included were all hydrocarbon-contaminated soils resulting from State-reportable releases, as well as those from non-reportable housekeeping releases. 


\subsection{GROUNDWATER PROTECTION}

At the present time, the YMP groundwater protection program consists of the monitoring activities presented in Section 6.1.5 of this SER. Background data are being collected on groundwater quality and quantity. The YMP has not caused any groundwater pollution or contamination and is in compliance with all applicable Federal and State regulations (Sections 3.1.4, 3.1.5, 3.1.15.1, and 3.2). 


\subsection{QUALITY ASSURANCE}

\subsection{OVERVIEW}

The quality and validity of monitoring data in this report have been ensured through implementation of a conventional Quality Assurance (QA) program. This QA program pertains to all aspects of monitoring, sampling, analysis, and subsequent data reduction and reporting operations in order to produce scientifically valid, traceable, and defensible data.

QA criteria are incorporated from conventional industry-wide standards and practices to meet applicable EPA and CFR requirements. Additional conventional QA programs may include, as appropriate, applicable portions of basic and supplementary requirements of ANSI/ASME Nuclear Quality Assurance (NQA) -1-1989 (ASME, 1989), as invoked through the DOE Office of Civilian Radioactive Waste Management (OCRWM) Quality Assurance Requirements and Description (QARD) document.

QA program requirements are further imposed on-subcontractors and vendors who are subjected to QA qualification requirements through a rigorous qualification process. These QA qualification requirements prescribe that stringent controls be invoked and implemented to ensure that equipment, devices, instruments and services, which directly affect the quality of data, are procured and supplied from qualified vendors. QA requirements also prescribe that processes and activities be performed in accordance with approved procedures.

QA controls, which ensure that data quality requirements are implemented, include the following practices:

- Personnel training is performed and documented prior to work initiation. 
- Work instructions and procedures are developed and technically reviewed before approval for use.

- A verbatim compliance policy for work performance, in accordance with approved procedures, is mandated for all work.

- Standards traceable to the National Institute of Standards and Technology (NIST) are used for conducting calibrations and performance checks of measuring and test equipment (M\&TE).

- $\quad M \& T E$ and operational equipment (OE), used for monitoring, sampling, analysis, and analysis and counting, are regularly calibrated at prescribed intervals.

- Operational status and accuracies of M\&TE and OE are independently checked on a continual basis by trained personnel.

- Discrepancies and nonconforming conditions, which may potentially affect data quality, are documented and evaluated in accordance with a structured and approved corrective action process.

- Technical data are reviewed prior to data reduction/analysis and reporting.

- Computer software programs, used for data reduction/analysis, are evaluated.

- Monitoring, sampling, analysis, and subsequent data reduction operations and related activities are regularly evaluated to verify effective implementation through performance of independent program audits and activity surveillances. 


\subsection{SAMPLE CONTROL}

All environmental samples are controlled in accordance with approved work instructions and procedures. These controlled documents specify approved methods and processes for sample collection, sample handling, chain-of-custody control, and analysis and data reporting.

Technicians are trained to ensure that samples are properly labeled, stored, and protected against loss or contamination. Samples are uniquely identified by markings either on the sample or its packaging. Sample transactions are documented on either a "Chain-of-Custody" form for external transfers or a "Sample Transfer" form, if transferred internally. Transfer recipients are required to verify that proper conditions and identification of samples are provided and maintained before accepting sample custody.

\subsection{SAMPLE ANALYSIS}

Analyses of samples are conducted in accordance with approved protocols, based on standard and approved methods. Personnel performing analyses and measurements are specifically trained for these work assignments prior to initiating work activities.

As prescribed by a scope of work, analysis programs selectively use sample blanks, spikes, and replicates to better determine accuracy and precision of methods and to eliminate bias. Subcontractors who measure or analyze samples are required to establish an equivalent QA control system. Results of measurements and analyses are reviewed and approved by technically qualified personnel. 


\subsection{INSTRUMENT CONTROL}

Instruments used to measure, monitor, test, or sample environmental conditions are procured, calibrated, controlled, and maintained in accordance with approved procedures. M\&TE, OE, and calibration standards, used to ensure instrumentation accuracy, are traceable to NIST. Equipment calibration frequencies and maintenance practices are prescribed in approved work instructions and procedures that are based upon manufacturers' recommendations. Provisions are made for frequency adjustments commensurate with reliability experience.

All calibrated equipment is subjected to periodic performance checks to verify adherence to EPA and YMP operation specifications. Calibrated equipment is routinely checked by trained field technicians, and appropriate maintenance adjustments are made to optimize data collection equipment performance. M\&TE and OE out-of-tolerance conditions are documented, and resolution is determined by either recalibration, rework, or replacement. Data affected by out-oftolerance conditions are reported and identified as "indeterninate" until resolution of the condition has been evaluated and data can be validated.

\subsection{DATA MANAGEMENT}

To preserve data integrity, monitoring and sampling data are recorded and handled in accordance with work instructions and procedures that are established and approved before data collection activities are performed. The efficiency of data reduction software is verified through formal acceptance tests prior to official use.

During data reduction activities or compilation for summary reports, raw data are validated and qualified to identify inconsistencies and anomalies. Data validation and qualification are performed by technical processor personnel who, using their professional judgment, compare the data to expected or predetermined ranges and historical data results. 
Discrepancies identified during data validation and qualification are evaluated. Decisions to include or eliminate suspect or nonverifiable data are determined during technical overviews by technically qualified personnel. 


\subsection{REFERENCES}

AA (Antiquities Act), 1979. "Antiquities Act of 1906," as amended. U.S. Code, Title 16, Sec. 431-433.

AIRFA (American Indian Religious Freedom Act), 1978. "American Indian Religious Freedom Act of 1978." U.S. Code, Title 42, Sec. 1996.

ARPA (Archaeological Resources Protection Act), 1979. "Archaeological Resources Protection Act." U.S. Code, Title 16, Sec. 470aa-47011.

ASME (American Society of Mechanical Engineers), NQA-1-1989. "Quality Assurance Program Requirements for Nuclear Facilities." September 15, 1989.

Beatley, J. C., 1976. Vascular Plants of the Nevada Test Site and central-south Nevada. ERDA. National Technical Information Service. TID-26881. Springfield, VA.

BLM (U.S. Bureau of Land Management), 1988. Right-of-Way Reservation N-47748, January 6, 1988.

BLM (U.S. Bureau of Land Management), 1989. Right-of-Way Reservation N-48602, October 10, 1989.

CAA (Clean Air Act), 1977. "Clean Air Act," as amended. U.S. Code, Title 42, Sec. 7401.

CERCLA (Comprehensive Environmental Response, Compensation, and Liability Act), 1980. "Comprehensive Environmental Response, Compensation, and Liability Act," as amended by "The Superfund Amendments and Reauthorization Act of 1986." U.S. Code, Title 42, Sec. 9601.

Collins, E., T. P. O'Farrell, and W. A. Rhoads, 1982. "Biologic Overview for the Nevada Nuclear Waste Storage Investigations, Nevada Test Site, Nye County, Nevada," EGG 1183-2460. EG\&G, Inc., Goleta, Calif.

CRWMS M\&O, 1995. "Diet of Desert Tortoises at Yucca Mountain, Nevada, and Implications for Habitat Reclamation," B00000000-01717-5705-00028. TRW Environmental Safety Systems, Inc., Las Vegas, NV.

CRWMS M\&O, 1996. "The Vegetation of Yucca Mountain: Description and Ecology," B00000000-01717-5705-00030, Rev. 00. TRW Environmental Safety Systems, Inc., Las Vegas, NV. 
CWA (Clean Water Act), 1972. "Federal Water Pollution Control Act of 1972," as amended by the "Clean Water Act of 1977," and the "Water Quality Act of 1987." U.S. Code, Title 33, Sec. 1251.

DOE (U.S. Department of Energy), 1986. "Environmental Assessment, Yucca Mountain Site, Nevada Research and Development Area, Nevada," DOE/RW-0073. Office of Civilian Radioactive Waste Management, Washington, D.C.

DOE (U.S. Department of Energy), 1990a. "General Environmental Protection Program," DOE Order 5400.1. U.S. Department of Energy, Washington, D.C.

DOE (U.S. Department of Energy), 1990b. "Research Design and Data Recovery Plan for Yucca Mountain Project." Yucca Mountain Project Office, Las Vegas, Nevada.

DOE (U.S. Department of Energy), 1991. "Floodplain Assessment of Surface-Based Investigations at the Yucca Mountain Site, Nye County, Nevada," YMP/91-11. Yucca Mountain Site Characterization Project Office, Las Vegas, Nevada.

DOE (U.S. Department of Energy), 1992a. "Floodplain Assessment of Site Characterization Activities at the Yucca Mountain Site, Nye County, Nevada," YMP/92-30. Yucca Mountain Site Characterization Project Office, Las Vegas, Nevada.

DOE (U.S. Department of Energy), 1992b. "Environmental Field Activity Plan for Terrestrial Ecosystems," YMP/91-41. Yucca Mountain Site Characterization Project Office, La.s Vegas, Nevada.

DOE (U.S. Department of Energy, 1992c. "Environmental Field Activity Plan for Archaeological Resources," YMP/92-15. Yucca Mountain Site Characterization Project Office, Las Vegas, Nevada.

DOE (U.S. Department of Energy), 1992d. "Environmental Field Activity Plan for Air Quality," YMP/91-42. Yucca Mountain Site Characterization Project Office, Las Vegas, Nevada.

DOE (U.S. Department of Energy), 1993. "Meteorological Data Collection at the Yucca Mountain Site," YMP-021-R2. Yucca Mountain Site Characterization Project Office, Las Vegas, Nevada.

DOE (U.S. Department of Energy), 1995a. "Summary of Socioeconomic Data Analyses Conducted in Support of the Radiological Monitoring Program During Calendar Year 1994." Yucca Mountain Site Characterization Project, Las Vegas, Nevada. 
DOE (U.S. Department of Energy), 1995b. "Waste Minimization and Pollution Prevention Awareness Plan," YMP/95-01. Yucca Mountain Site Characterization Project, Las Vegas, NV.

DOE (U.S. Department of Energy), 1995c. "Environmental Field Activity Plan for Water Resources: Water Quantity Component," Revision 1, YMP/90-50. Office of Civilian Radioactive Waste Management, Las Vegas, NV.

DOE (U.S. Department of Energy), 1996a. "Summary of Socioeconomic Data Analyses Conducted in Support of the Radiological Monitoring Program from January 1995 to April 1996." Yucca Mountain Site Characterization Project, Las Vegas, NV.

DOE (U.S. Department of Energy), 1996b. "Environmental Regulatory Compliance Plan," YMP/92-2. Yucca Mountain Site Characterization Office, Las Vegas, NV.

EO (Executive Order) 11988, Office of the President, 1977a. "Floodplain Management." 42 Federal Register 101, Washington, D.C.

EO (Executive Order) 11990, Office of the President, 1977b. "Protection of Wetlands." 42 Federal Register 101, Washington, D.C.

EO (Executive Order) 12856, Office of the President, 1993. "Federal Compliance with Right-to-Know Laws and Pollution Prevention Requirements." Washington, D.C.

ESA (Endangered Species Act), 1973. "Endangered Species Act of 1973." U.S. Code, Title 16, Sec. 1531.

FLPMA (Federal Land Policy and Management Act), 1976. "Federal Land Policy and Management Act of 1976." U.S. Code, Title 43, Sec. 1701.

FPPA (Farmland Protection Policy Act), 1981. "Farmland Protection Policy Act of 1981." U.S. Code, Title 7, Sec. 4201.

Kartesz, J. T., 1988. "A Flora of Nevada." Ph. D. dissertation, University of Nevada, Reno, Nevada.

Kartesz, J. T., and R. J. Pankhurst, 1994. "A Synonymized Checklist of the Vascular Flora of the United States, Canada and Greenland," 2 volumes, 2nd edition. Timber Press, Portland, OR.

McNatt, R. M., 1990. Letter from R. M. McNatt to C. P. Gertz. U.S. Fish and Wildlife Service Consultation and Biological Opinion on the potential for adverse impacts on the desert tortoise from site characterization activities. February 9, 1990. 
NAC (Nevada Administrative Code), Chapter 445, Sec. A.345-.348, "Water Pollution Control." State of Nevada.

NAGPRA (Native American Graves Protection and Repatriation Act), 1990. Public Law 101-106, U.S. Code, Title 25, Sec. 3001-3013.

Navarre, R.J., 1988. Letter from R. J. Navarre to C. P. Gertz. U.S. Fish and Wildlife Service (Reno, Nevada) consultation regarding wetlands and threatened and endangered species at Yucca Mountain. February 23, 1988.

NEPA (National Environmental Policy Act), 1969. "National Environmental Policy Act of 1969." U.S. Code, Title 42, Sec. 4321.

NHPA (National Historic Preservation Act), 1966. "National Historic Preservation Act of 1966." U.S. Code, Title 16, Sec. 470.

NWPA (Nuclear Waste Policy Act), 1982. "Nuclear Waste Policy Act of 1982," as amended by the "Nuclear Waste Policy Amendments Act (NWPAA) of 1987." Public Law 97-425, U.S. Code, Title 42, Sec. 10101.

O'Farrell, T. P., and E. Collins, 1983. "1982 Biotic Survey of Yucca Mountain, Nevada Test Site, Nye County, Nevada," EGG-10282-2004. EG\&G, Inc., Goleta, Calif.

PA (Programmatic Agreement), 1988. "Programmatic Agreement Between the United States Department of Energy and the Advisory Council on Historic Preservation for the Nuclear Waste Deep Geologic Repository Program, Yucca Mountain, Nevada."

PPA (Pollution Prevention Act), 1990. "Pollution Prevention Act of 1990." Public Law 101-508; 104 Stat. 1388, U.S. Code, Title 42, Sec. 13010 et seq.

RCRA (Resource Conservation and Recovery Act), 1976. "Resource Conservation and Recovery Act of 1976." U.S. Code, Title 42, Sec. 6901.

SDWA (Safe Drinking Water Act), 1974. "Safe Drinking Water Act of 1974." U.S. Code, Title 42 , Sec. 300(f)-(j)-10.

U.S. Bureau of the Census, 1997. "County Population Estimates."

Website: http://www.census.gov/population/www/estimates/countypop.html.

U.S. Bureau of the Census, Washington, D.C.

USGS (U.S. Geological Survey), 1996a. Provisional Data on Ground-Water Levels and Springflows in the Yucca Mountain Region for the Period January-March 1996. 
USGS (U.S. Geological Survey), 1996b. Provisional Data on Ground-Water Levels and Springflows in the Yucca Mountain Region for the Period April-June 1996.

USGS (U.S. Geological Survey), 1996c. Provisional Data on Ground-Water Levels and Springflows in the Yucca Mountain Region for the Period July-September 1996.

USGS (U.S. Geological Survey), 1996d. Provisional Data on Ground-Water Levels and Springflows in the Yucca Mountain Region for the Period October-December 1996.

USGS (U.S. Geological Survey), 1996e. "Selected Ground-Water Data for Yucca Mountain Region, Southern Nevada and Eastern California, through December 1994," Open-File Report 96-205. U.S. Geological Survey, Denver, CO. 


\section{LIST OF ACRONYMS}

AA

ACHP

AGL

AIRFA

AMESH

ARPA

BLM

BP

CAS

CAA

CERLA

$\mathrm{CFC}$

CFR

COE

CRM

CRWMS M\&O

CWA

CY

DOE

EA

EFAP

EHS

EIC

EIS

EO

EPA
Antiquities Act

Advisory Council on Historic Preservation

Above Ground Level

American Indian Religious Freedom Act

Assistant Manager for Environment, Safety, and Health

Archaeological Resources Protection Act

Bureau of Land Management

Before present

Continuous air samplers

Clean Air Act

Comprehensive Environmental Response, Compensation and Liability Act

Chlorofluorocarbon

Code of Federal Regulations

Corps of Engineers

Continuous radon monitor

Civilian Radioactive Waste Management System Management and

Operating Contractor

Clean Water Act

Calendar Year

U.S. Department of Energy

Environmental Assessment

Environmental Field Activity Plan

Extremely Hazardous Substances

Electret ionization chamber

Environmental Impact Statement

$$
\text { Executive Order }
$$

U.S. Environmental Protection Agency 
EPCRA

EPD

ERCP

ESA

ES\&H

ESF

ESHCD

ESP

FF

FIFRA

FLPMA

FPPA

FR

FY

GERT

GET

GIS

GSF

HCFC

HS

M\&TE

MSDS

NAC

NAFR

NAGPRA

NCAI

NDEP

NEPA

NF
Emergency Planning and Community Right-to-Know Act

Environmental Programs Department

Environmental Regulatory Compliance Plan

Endangered Species Act

Environmental, Safety, and Health

Exploratory Studies Facility

Environmental, Safety, and Health Compliance Department

Ecological Study Plot

Far-field

Federal Insecticide, Fungicide and Rodenticide Act

Federal Land Policy and Management Act

Farmland Protection Policy Act

Federal Register

Fiscal Year

General Radiological Safety Training

General Employee Training

Geographic Information System

Ground Surface Facility

Hydrochlorofluorocarbon

Hazardous Substances

Measuring and Test Equipment

Material Safety Data Sheet

Nevada Administrative Code

Nellis Air Force Base Bombing and Gunnery Range

Native American Graves Protection and Repatriation Act

National Congress of American Indians

Nevada Division of Environmental Protection

National Environmental Policy Act

Near-field 
NHPA

NIST

NOI

NPDES

NPS

NRC

NTS

NWPA

OCRWM

OE

OSHA

OTCR

PA

PIC

$\mathrm{PM}_{10}$

PPA

PSD

QA

QARD

QATSS

RCD

RCRA

RFA

ROWR

$\mathrm{RQ}$

SARA

SCEP

SDWA

SER
National Historic Preservation Act

National Institute of Standards and Technology

Notice of Intent

National Pollutant Discharge Elimination System

National Park Service

Nuclear Regulatory Commission

Nevada Test Site

Nuclear Waste Policy Act

Office of Civilian Radioactive Waste Management

Operational Equipment

Occupational Safety and Health Administration

Official Tribal Contact Representative

Programmatic Agreement

Pressurized ionization chamber

Particulate Matter 10 micrometers or less in diameter

Pollution Prevention Act

Prevention of Significant Deterioration

Quality Assurance

Quality Assurance Requirements and Description

Quality Assurance Technical Support Services

Radiological Control Division

Resource Conservation and Recovery Act

Request for Authorization

Right-of-Way Reservation

Reportable Quantity

Superfund Amendments and Reauthorization Act

Site Characterization Effects Program

Safe Drinking Water Act

Site Environmental Report 


$\begin{array}{ll}\text { SHPO } & \text { State Historic Preservation Office } \\ \text { TBM } & \text { Tunnel-boring machine } \\ \text { TLD } & \text { Thermoluminescent dosimeter } \\ \text { TPH } & \text { Total Petroleum Hydrocarbons } \\ \text { TSCA } & \text { Toxic Substances Control Act } \\ \text { TSD } & \text { Treatment, Storage, and Disposal } \\ \text { UIC } & \text { Underground Injection Control } \\ \text { URTD } & \text { Upper Respiratory Tract Disease } \\ \text { USAF } & \text { U.S. Air Force } \\ \text { USFWS } & \text { U.S. Fish and Wildlife Service } \\ \text { USGS } & \text { U.S. Geological Survey } \\ \text { YAP } & \text { Yucca Mountain Administrative Procedure } \\ \text { YMP } & \text { Yucca Mountain Site Characterization Project } \\ \text { YMSCO } & \text { Yucca Mountain Site Characterization Office }\end{array}$

